US Army Corps

of Engineers ${ }_{\circledast}$

Engineer Research and

Development Center

\title{
Guidelines for Minimizing Potable Water Loss Due to Water Distribution System Flushing
}

Elisabeth M. Jenicek, Victoria E. Heath, Noah W. Garfinkle,

January 2020 and Andy Hur

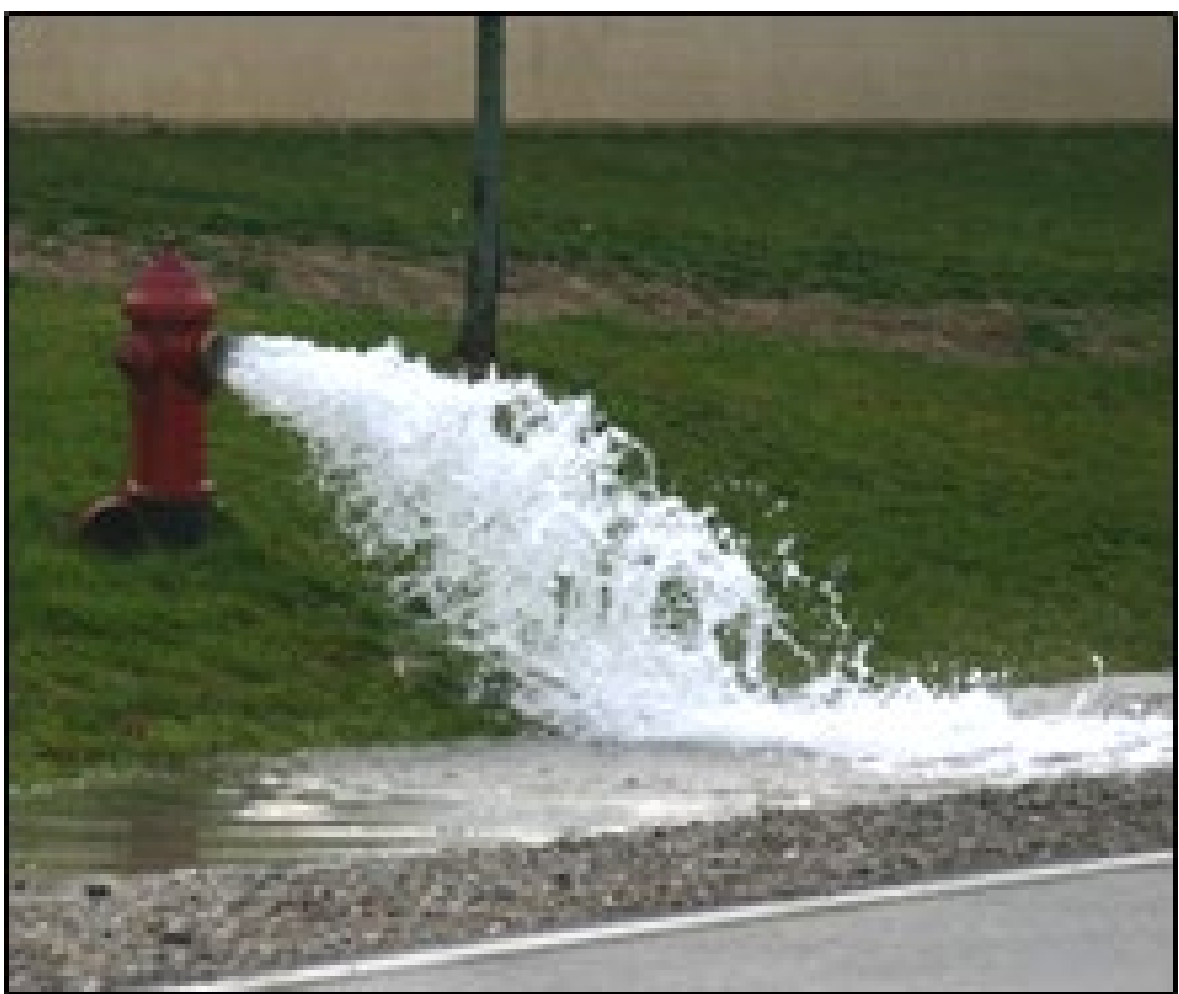


The U.S. Army Engineer Research and Development Center (ERDC) solves the nation's toughest engineering and environmental challenges. ERDC develops innovative solutions in civil and military engineering, geospatial sciences, water resources, and environmental sciences for the Army, the Department of Defense, civilian agencies, and our nation's public good. Find out more at www.erdc.usace.Army.mil.

To search for other technical reports published by ERDC, visit the ERDC online library at http://acwc.sdp.sirsi.net/client/default. 


\section{Guidelines for Minimizing Potable Water Loss Due to Water Distribution System Flushing}

Elisabeth M. Jenicek, Noah W. Garfinkle, and Andy Hur

U.S. Army Engineer Research and Development Center (ERDC)

Construction Engineering Research Laboratory (CERL)

2902 Newmark Drive

Champaign, IL 61824

Victoria Heath

Department of Civil and Environmental Engineering

Grainger College of Engineering

University of Illinois at Urbana-Champaign

205 North Matthews Avenue

Urbana, IL 61801

Final Technical Report (TR)

Approved for public release; distribution unlimited.

Prepared for Office of the Assistant Secretary of the Army, Installations, Energy and Environment OASA(IE\&E)

Washington, DC 20310

Under Military Interdepartmental Purchase Request (MIPR) 11097857, "Development of Guidelines for Minimizing Potable Water Loss due to System Flushing." 


\section{Abstract}

Executive Order 13834 (White House 2018) mandates the reduction of water consumption from potable and non-potable water distribution systems to increase readiness and security. Flushing of water distribution systems potentially wastes large quantities of water. This work developed and administered an installation survey to assess the prevalence of potable water flushing at Army installations, and used the information gathered from that survey to identify available technologies to recommend best management practices that reduce flushing and/or that reduce water loss due to flushing. Specific recommendations include changes to lessen the need to flush and practices that optimize necessary flushing.

DISCLAIMER: The contents of this report are not to be used for advertising, publication, or promotional purposes. Citation of trade names does not constitute an official endorsement or approval of the use of such commercial products. All product names and trademarks cited are the property of their respective owners. The findings of this report are not to be construed as an official Department of the Army position unless so designated by other authorized documents. 


\section{Contents}

Abstract nigures

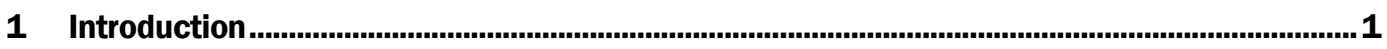

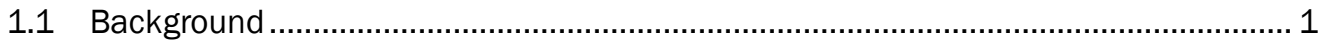

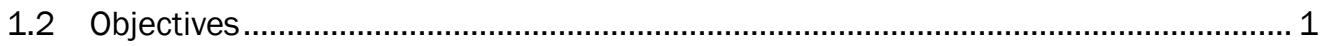

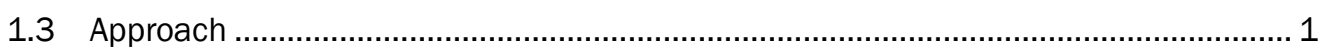

1.4 Scope

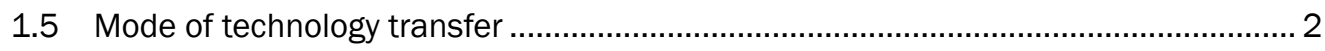

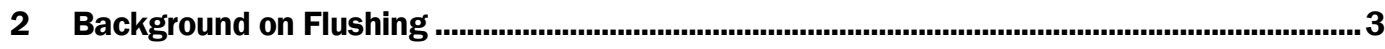

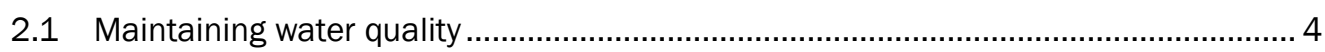

2.1.1 Bacteria control ......................................................................................................... 4

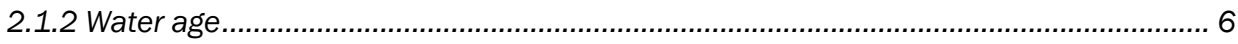

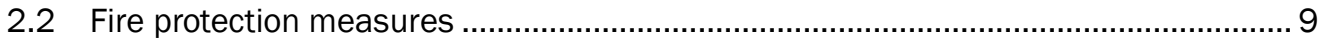

2.2.1 Fire flow testing …………………………………......................................... 10

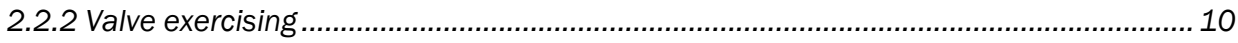

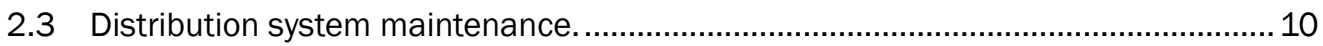

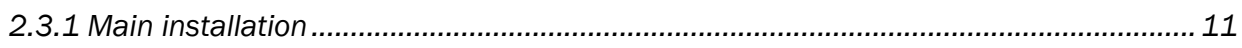

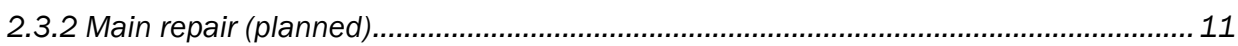

2.3.3 Main break (unplanned) .................................................................................. 12

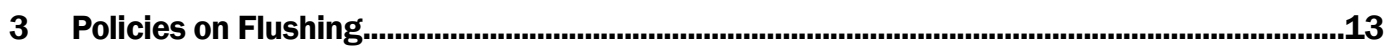

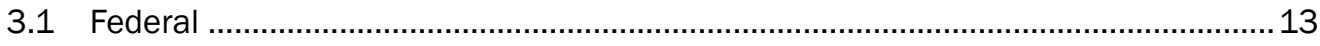

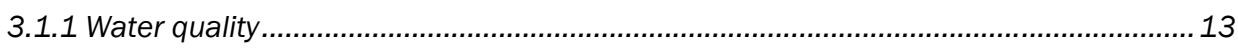

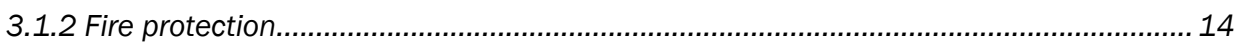

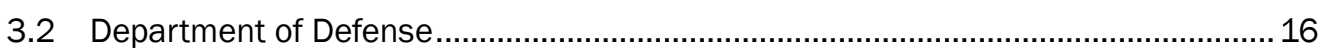

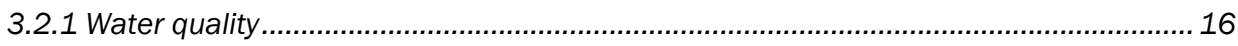

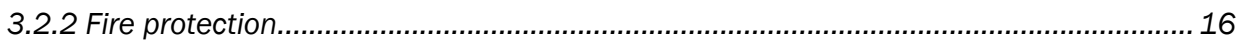

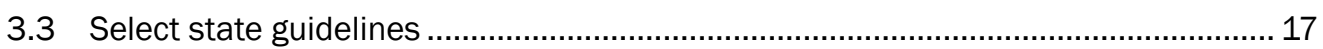

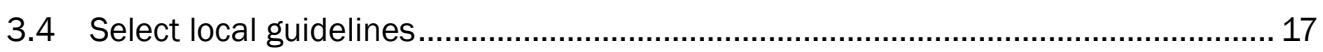

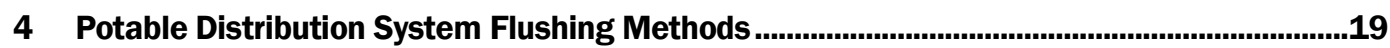

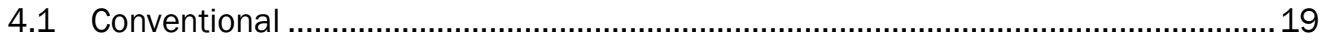

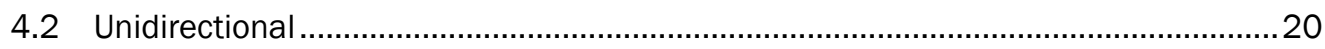

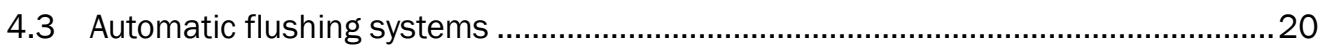

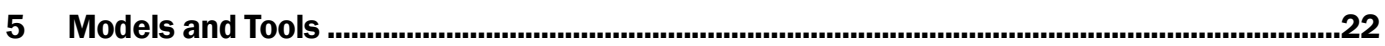

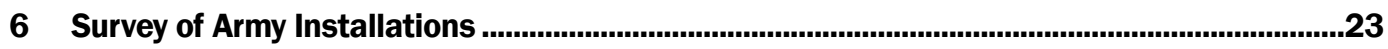

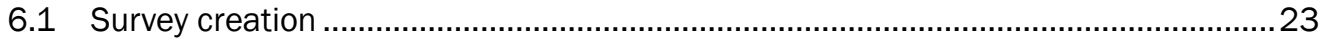

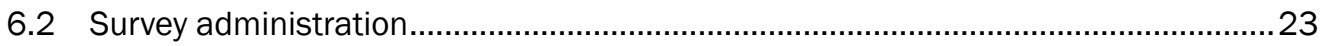




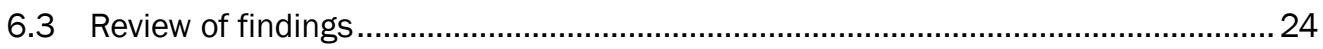

6.3.1 Quantity of potable water used for quality and fire flow flushing vs. population

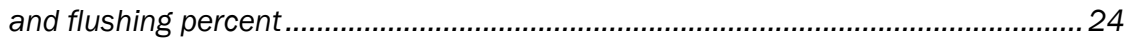

6.3.2 Effect of management and source water on flushing program frequency ................... 26

6.3.3 Effect of management and source water on flushing duration deciding factor ............26

6.3.4 Effect of management and source water on flushing reason........................................ 27

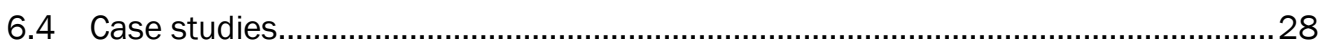

6.4.1 Fort Hood, TX: Large site, high flushing (outlier), auto-flusher proposal .......................28

6.4.2 Fort Leonard Wood, Missouri: Large site, high flushing (outlier) .................................. 29

6.4.3 Fort Bragg, North Carolina: Large site and low flushing............................................. 30

6.4.4 Fort George Meade, Maryland: Use of Neutral Output Elimination System (NODES)

6.4.5 Fort Greely, Alaska: Small size and low flushing.................................................... 33

6.4.6 Fort Irwin, California: Arid climate and regular flushing ............................................. 33

6.4.7 Fort Buchanan, Puerto Rico: Small site, low flushing, and non-potable supply..............34

6.4.8 Fort Benning, Georgia: Large population, high flushing, and auto-flushers .................. 34

6.4.9 Fort A.P. Hill, Virginia: Use of Fire Flow Pro .............................................................. 35

6.4.10 Fort Huachuca, Arizona: Large site and arid climate ................................................ 35

6.4.11 Fort Carson, Colorado: Decreased storage capacity................................................. 38

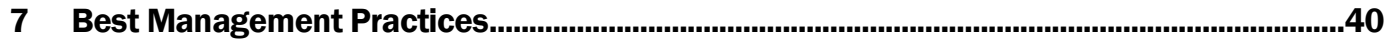

7.1 Optimizing treatment and distribution system ................................................40

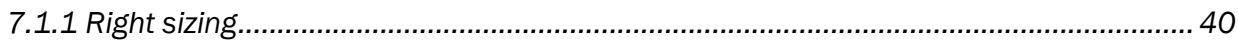

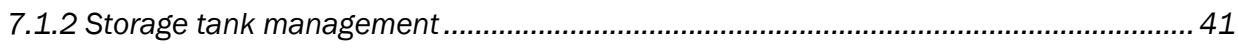

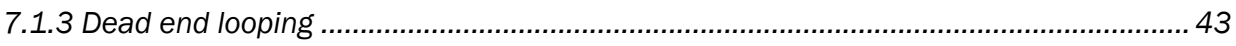

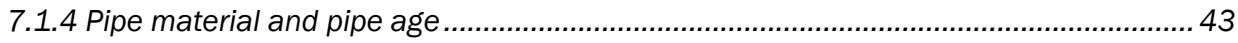

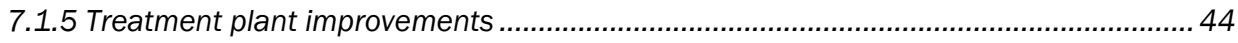

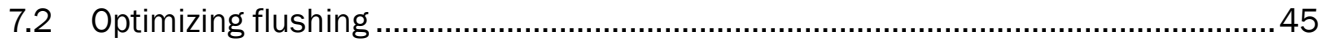

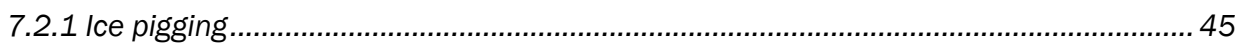

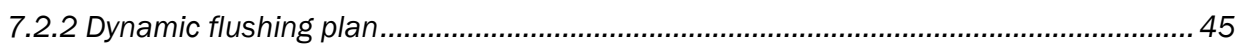

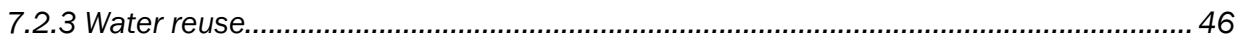

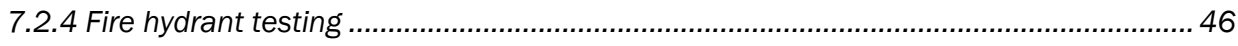

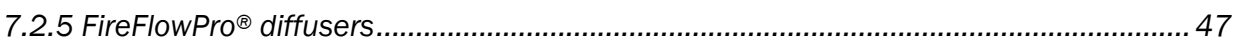

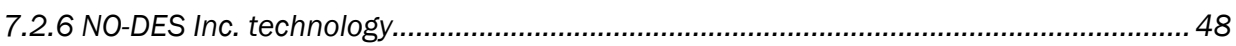

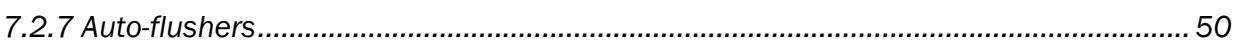

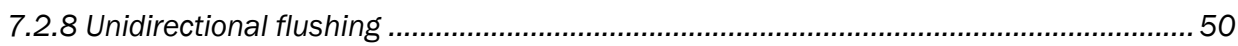

8 Conclusions and Recommendations ................................................................................51

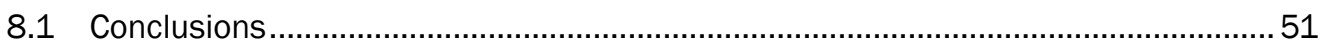

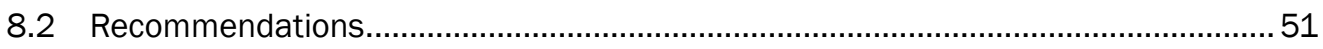

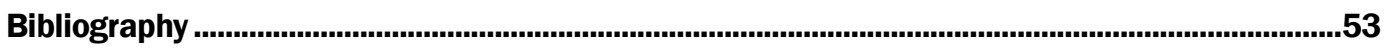

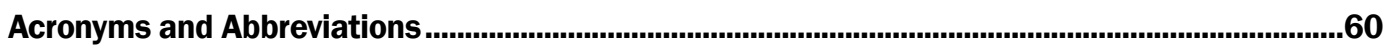

Appendix A: Illinois Section American Water Works Association Survey ..................................61

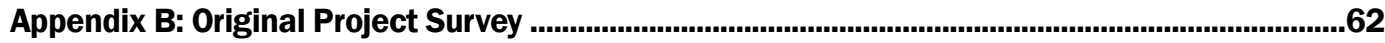




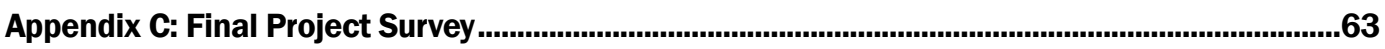

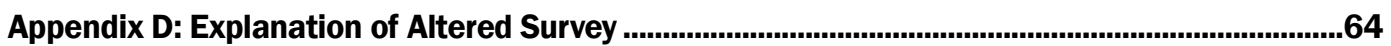

Appendix E: Summary of Survey Results..........................................................................66

Appendix F: Water Audit Classifications ............................................................................................67

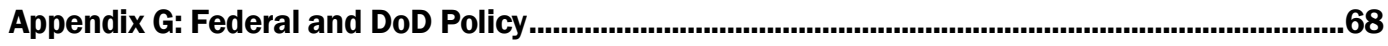

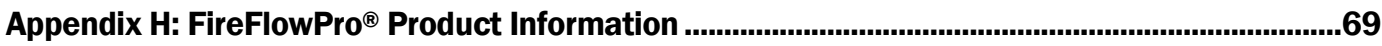

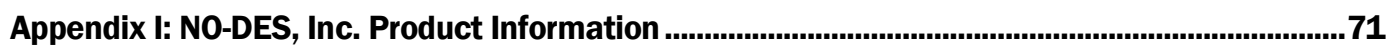

Report Documentation Page (SF 298) ..................................................................................73 


\section{Figures}

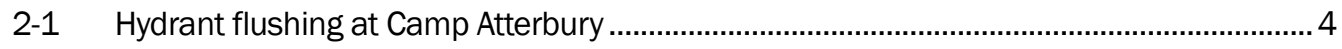

2-2 Fort Bragg potable water with brown discoloration............................................................ 7

2-3 Correlation between water age (disinfectant residual as free chlorine) and TTHM, a regulated disinfectant byproduct

2-4 Correlation between water age (disinfectant residual as free chlorine) and Haloacetic Acids (HAA5) regulated disinfectant byproducts (USEPA 2013) ...................... 8

2-5 Common water system actions to control nitrification from a 2004 survey........................ 9

2-6 Old wooden water mains at Blue Grass Army Depot ..........................................................11

4-1 Automatic flusher at Blue Grass Army Depot....................................................................21

6-1 Quantity of potable water used for quality and fire flow flushing vs. population and flushing percent...........................................................................................25

6-2 Quantity of potable water used for quality and fire flow flushing vs. population and flushing percent excluding outliers .....

6-3 Flushing frequency divided by resources management type (left) and flushing frequency by source water (right)........................................................................26

6-4 Flushing duration factor divided by resources management type (left) and flushing duration factor by source water (right) ..............................................................2

6-5 Flushing reason divided by resources management type (left) and flushing reason by source water (right)............................................................................................28

6-6 Fort A.P. Hill monthly flushing in gallons over the course of 3 years. Reduction attributed to the use of the Fire Flow Pro diffuser system ..............................37

6-7 Water consumption (pumped) at Fort Huachuca from 1992 to 2017 plotted against Fort population ......................................................................................37

7-1 A Texas American Waters Bernard Acres Tank TTHM (and other DBP) removal with pressure differences in spray stripping.

7-2 NO-DES truck-mounted system in operation ...................................................................

7-3 Two sets of pipe section before and after NO-DES. Top pictures are before images. Bottom pictures are after NO-DES images. 


\section{Preface}

This study was conducted for the Office of the Assistant Secretary of the Army, Installations, Energy and Environment OASA(IE\&E), via Military Interdepartmental Purchase Request (MIPR) 11097857, "Development of Guidelines for Minimizing Potable Water Loss due to System Flushing." The technical monitor was Dr. Marc Kodack, Office of the Deputy Assistant Secretary of the Army for Energy and Sustainability, ODASA(ES). Final report review was done by Paul Volkman, ODASA(ES).

The work was managed and executed by the Energy Branch, of the Facilities Division, U.S. Army Engineer Research and Development Center, Construction Engineering Research Laboratory (ERDC-CERL). At the time of publication, Giselle Rodriguez was Chief of the Energy Branch and Dr. Christa Woodley was Acting Chief of the Facilities Division. The Deputy Director of ERDC-CERL was Dr. Kirankumar Topudurti and the Director was Dr. Lance Hansen.

Special appreciation is owed to the installation points of contact for providing data and information that were invaluable to this study and for reviewing this report. These individuals are: Charles Auer, Mark Fincher, and Tom Horn of Fort Benning, Charles Beach of Fort Knox, Joanna Brown of Fort Riley, John Burgess of USAG Miami, Darryl Butler of Fort Bragg, Melanie Chaballe of USAG Schinnen, Craig Collins and Robert Diaz of White Sands Missile Range, Lissete Cortez of Fort Bliss, Diane Covell of Fort Drum, Bill Douglas of BAE Systems for Radford Army Ammunition Plant, Phil Facer of Fort Campbell, Gef Fisher of Fort A. P. Hill and Gary Manville of American Water for Fort A. P. Hill, Lyle Fogg of Joint Base Lewis-McChord, Steven Golub of the U.S. Army Health Command out of Fort Sam Houston, Beth Grosscup of Fort George Meade, Jim Casey and Vincent Guthrie of Fort Carson, Christian Hawkinson of Rock Island Arsenal, Paul Herzer of Carlisle Barracks, Christopher Higgins of Fort Huachuca, Luke Horace of the City of Augusta Utility and Glenn Hartzog for Fort Gordon, Linda Howard of Fort Polk, Beckie Hurley of Hurco Technologies, James Johnson of USAG Daegu, Mark Lewis of Fort Detrick, Mike Maier and David Ondre of Picatinny Arsenal, Dennis Meyers of Fort Sill, Mike Miller of Fort McCoy, Anibal Negron of Fort Buchanan, Daniel O'Brien of Fort Belvoir, Gary Ogden of Fort Lee, Sang Hyon Pak of USAG Yongsan, Keith Pendleton of Fort Leonard Wood, Tami Relph of the Naval Facilities Engineering Command at Port Hueneme, Chad Reynolds of 
American Water for Fort Hood, Fred Sandgren of Fort Wainwright, Steven Sheffey of Dugway Proving Grounds, Gregory Skaggs of Yuma Proving Ground, Norbert Soehn of USAG Heidelberg (I), Al Thomas of Fort Greely (Water Contractor), Richard Valcourt of the Natick Soldier System Center, President Chris Wilkinson of NO-DES Inc., Randall Wilson of Redstone Arsenal, Brett Wobker of Fort Leavenworth, Chris Woodruff of Fort Irwin, and Giovanni Zanon of USAG Vicenza.

COL Teresa A. Schlosser was Commander of ERDC, and Dr. David W. Pittman was the Director. 


\section{Introduction}

\subsection{Background}

The flushing of water distribution systems on Army installations is an essential part of a process that maintains the systems in optimal condition and that ensures installations' fire protection capabilities. Army Regulation (AR) 420-1, Army Facilities Management (HQDA 2008) requires flushing. However, unsophisticated flushing protocols can potentially cause significant water losses that can affect an installation's total water usage (PNNL 2012a-f, PNNL 2013a,b). There is a need for best management practices (BMPs) that can significantly reduce water loss while maintaining regulatory compliance. This work was undertaken to review and optimize the flushing of distribution systems to help installations achieve and maintain system stability and readiness.

\subsection{Objectives}

The overall goal of this work was to inform resource management to maintain installation readiness through the development, protection, and restoration of the nation's water (U.S. Army War College 2015). Specific objectives were to evaluate and recommend BMPs that will reduce the loss of potable water during water distribution system flushing.

\subsection{Approach}

The objectives were completed through the following steps:

1. A literature review was conducted to explore flushing technologies available to minimize water loss due to flushing.

2. A review was done of relevant federal, state, local, industry, and Army policies.

3. An installation survey was developed and administered to assess the prevalence of potable water flushing at Army installations (see section 6.4, "Case studies") and to identify available technologies that reduce flushing and/or that reduce water loss due to flushing.

4. BMPs were identified and documented. 


\subsection{Scope}

This project focused on the outcomes of past water use studies and data disaggregation efforts identified by the sponsoring organization's representative. This work could be replicated elsewhere by considering unique aspects of each installation's water system.

\subsection{Mode of technology transfer}

It is anticipated that the information gathered and generated by this work will support changes to policy and specifications, and will inform efforts to improve water resilience, to enhance water security (and the allocation of security funds), and to reduce water consumption. 


\section{Background on Flushing}

Water distribution systems have been developed and operated for a variety of reasons, one of which is to distribute potable water. In some places, the need for non-potable water is great enough to support alternative water supply configurations, most commonly by operating dual (potable and non-potable) distribution systems. However, in most locations water systems established to provide potable water for household use are augmented and enlarged to provide water for irrigation, car washing, industrial processes, fire protection/suppression, and other purposes. This report focuses on flushing of potable water distribution systems.

Since multiple uses rely on the same distribution system, those users must work together. Notably, the water utility has important partners those that provide fire protection. The water utility must work together with local fire officials, building code officials, and others to effectively and efficiently promote fire protection. Good communication between all involved parties is essential to protect property and life.

When a distribution system is flushed, it loses a variable fraction of the total potable water input to the system. It can be difficult to obtain an exact measure of water consumption and losses at installations since individual facilities are metered. ${ }^{*}$ However, a review of water consumption at some of the eight pilot net zero water installations (PNNL 2012a-g, PNNL 2013a-b) revealed that the average percentage of the end-use "loss" and "unknown" categories (of which flushing is a part) totaled $24.6 \%$ of total water consumption. This amount corresponds with results of discussions at the FY2012 Net Zero Installations Workshop where installation water managers named water distribution system condition/water loss as their biggest concern.

Similarly, water loss was shown to be a significant component in the installation water models that the Engineer Research and Development Center, Construction Engineering Research Laboratory (ERDC-CERL) created for 29 Installation Water Sustainability Assessments under the sponsorship of the Office of the Deputy Assistant Secretary of the Army for Energy and Sustainability (ODASA[ES]). At some of these sites, distribution system flushing alone accounted for up to $30 \%$ of the total installation water

* AWWA's M36 Water Audits and Loss Control Programs contains the accepted methods for quantifying authorized consumption, unauthorized consumption, and apparent losses, which are used to calculate real losses (leakage). 
use. These large measured losses justify an investigation into why flushing occurs and how the practice can be best managed to reduce losses.

Flushing of water systems on Army installations takes place for a variety of reasons. Certain degrees of distribution system flushing are mandated by federal law, state law, local jurisdictions, and Army policy (Policies on Flushing). Flushing is typically required to protect water quality, to ensure fire flow (Figure 2-1), and to remove contaminants introduced during construction or system maintenance. The following sections summarize common reasons for system flushing. Note that the listed reasons are not exhaustive; individual systems often have unusual and unpredictable needs for flushing.

Figure 2-1. Hydrant flushing at Camp Atterbury.

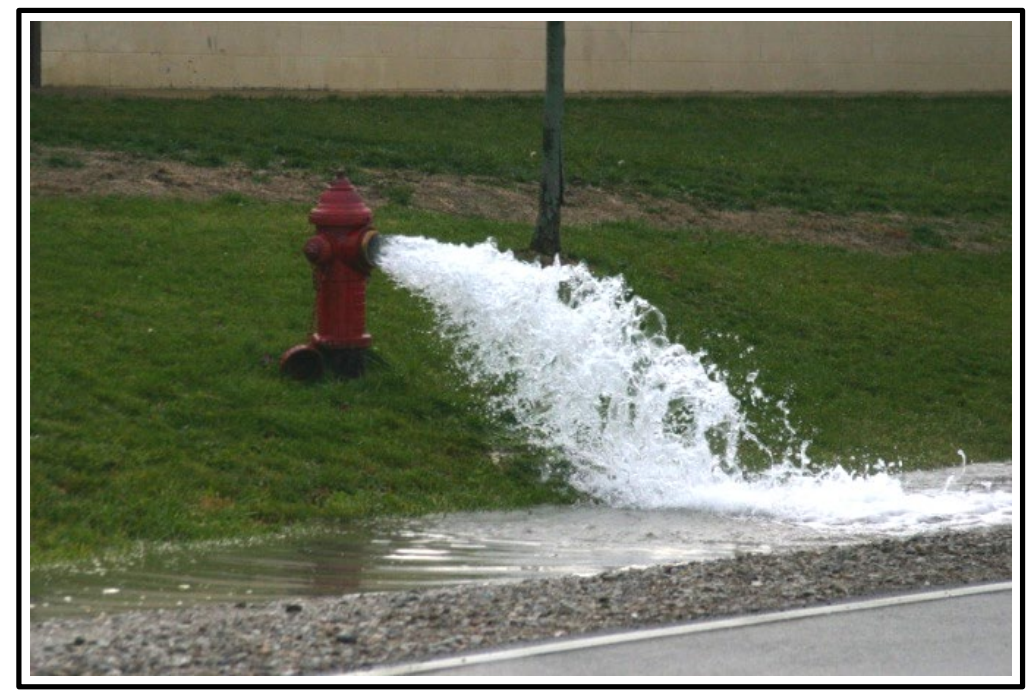

\subsection{Maintaining water quality}

Many water utilities operate flushing programs to maintain good water quality in the distribution system (AWWA 2016). Water quality within the distribution system is monitored by testing for bacteria, which ensures control of current bacteria levels, and by testing for disinfectant byproducts and chlorine residuals, which ensures the control of future bacteria growth as a function of water age.

\subsubsection{Bacteria control}

The purpose of a potable water distribution system is to supply safe drinking water for consumption. However, bacteria-harboring films accumulate 
in the system piping over time. The presence of bacteria and other pathogens can seriously jeopardize water quality. For this reason, bacteria levels are highly regulated; the control of bacteria and prevention of other pathogens is crucial to supplying potable water.

Flushing is commonly used to control bacteria formation since flushing scours away the bacteria-harboring films and replaces any water in the lines with fresh finished water. Since the bacteria-harboring films usually re-develop over time, flushing is not a permanent solution to the problem of bacterial contamination. The process must be performed at a frequency that matches the film's development.

\subsubsection{Sedimentation}

Sediments can accumulate in the pipes due to corrosion and scaling (AWWA 2017b). Other unusual circumstances can also cause sediments to infiltrate the system. For example, nearby construction or vibrations in the ground can shake loose otherwise bound deposits. ${ }^{*}$ Removal of solids and scouring of water mains keeps pipes in working order by maintaining a clear flow path and removing bacteria-hosting deposits. To properly conduct flushing operations for this purpose, the water flowing in the pipes must reach velocities capable of pushing the otherwise settled sediments out of the lines. These higher-than-normal velocities scour the insides of the distribution piping, helping to clean out any accumulated soils or silt.

\subsubsection{Tuberculation}

Tuberculation is the formation of small knob-like rust formations (tubercles) usually in unlined cast iron piping (AWWA 2017b). Flushing at higher-than-normal water velocities can scour the inside of water lines and thereby remove iron deposits that would have otherwise harbored bacteria or led to further corrosion by accumulation. The presence of tubercles can be attributed to the pipe material used, and to the $\mathrm{pH}$ or composition of the source water, or to the presence of stagnant water sections.

\footnotetext{
* Personal communication between Victoria Heath, ERDC-CERL and Beth Grosscup, Fort George Meade, Maryland, 2018.
} 


\subsubsection{Biofilm}

Bacteria are also prevalent in biofilms that adhere to the inner walls of distribution mains. The accumulated film can host a number of bacteria; removal of the film can help control bacteria in the system. The biofilm can host coliforms and jeopardize the total coliform standard. The prevalence of biofilms increases in conditions of low flow and high-water temperatures, and in the presence of pipe corrosion (Ohio AWWA 2014). Biofilms are most commonly removed by flushing at a velocity that scours the inner walls of the pipe. Their presence can be attributed in part to the $\mathrm{pH}$ or composition of the source water, and to the amount of time stagnant water stands in the pipes.

\subsubsection{Customer complaint}

Customer complaints are usually based on water taste, color (Figure 2-2), or odor. Most of these conditions can be attributed to the films just described (sedimentation, tuberculation, or biofilm). By keeping good records of complaints, installations can determine concentrated areas of the complaints. Focusing attention on these problem areas can help identify specific problems. For example, water quality problems commonly occur on the system's periphery where stagnant water stands and films accumulate. Flushing removes many of the deposits, sediment, and other materials that can affect taste and odor. In many complaint-related cases, spotflushing or conventional flushing is used to flush out the foul water and draw in fresh. This does not conserve water, but it does preventively address the issue. The only other way to improve taste and odor would be to prevent stagnation and the accumulation of films.

\subsubsection{Water age}

Water's quality diminishes with its age. As water sits unused in pipes, it ages and stagnates. Finished water in the distribution system can stagnate for a number of reasons (low demand, oversized pipe diameter, dead-end location, loss of pressure, etc.). Stagnant water can increase the production of bacteria-harboring films and the conditions that cause stagnant water also allow time for undesirable reactions between the water and its disinfectant. 
Figure 2-2. Fort Bragg potable water with brown discoloration.

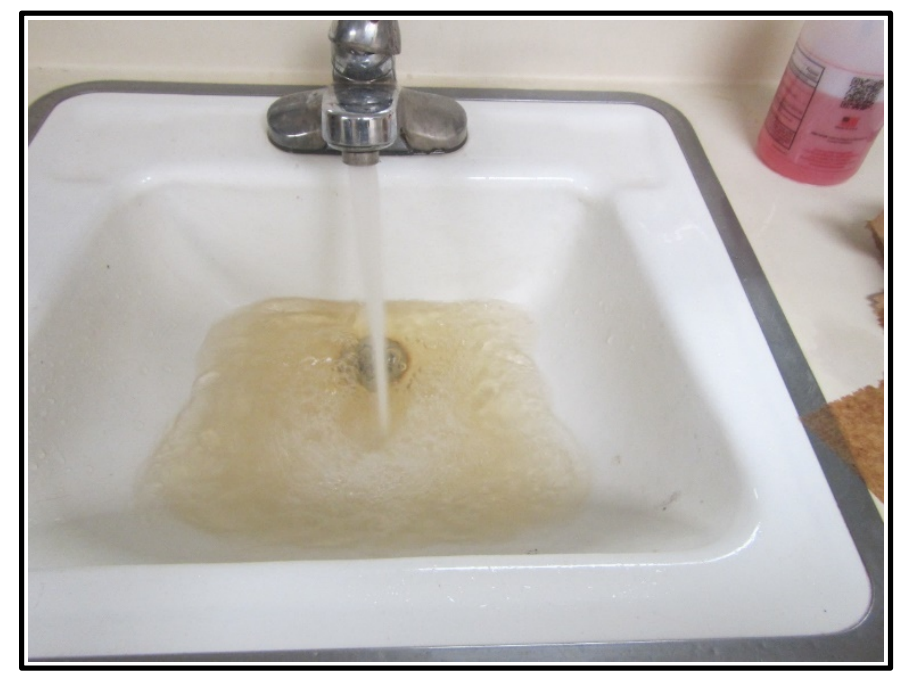

Operational events can also contribute to the conditions that cause stagnant water, e.g., when buildings remain unoccupied for long time periods, a common occurrence at force projection platforms. The ability for bacteria to form in this stagnant environment is only limited by the presence of chlorine disinfectant (added during the treatment process). As the disinfectant residual decreases (and is used) bacteria can begin to grow.

There are only two ways to truly achieve a net reduction in water age in a system, by increasing demand or by reducing the storage volume of the system (AWWA 2017a). Flushing can be conducted to remove old water, essentially creating an artificial demand (that will reduce stagnation). The conditions of the aged water can also be addressed by treating its specific undesirable qualities (including disinfection byproducts and High Nitrates).

\subsubsection{Disinfection byproducts}

Water treatment disinfection can generate contaminants called disinfection byproducts (DBPs) that are caused by the reaction of source water with treatment chemicals (Hruday and Charrois 2012). These reactions occur as water ages and their concentration can be graphed over time (Figures 2-3 and 2-4). Note that Figures 2-3 and 2-4 graph the correlation between water age and only two regulated DBPs (Trihalomethanes [TTHM] and volatile HAA5s). (Many more individual species exist.) Disinfection byproducts can be controlled by flushing the system of aged water, by making changes to the treatment regimen, and by making engineered changes to the distribution system. Treatment process improvements include the use of alternative disinfectants and pre-oxidants, aeration, and or organic matter removal 
(enhanced coagulation, activated carbon, ion exchange, high-pressure membranes). Aeration helps to remove volatile DBPs only. Chapter 7, "Best Management Practices," discusses these removal techniques in more detail.

Figure 2-3. Correlation between water age (disinfectant residual as free chlorine) and TTHM, a regulated disinfectant byproduct.

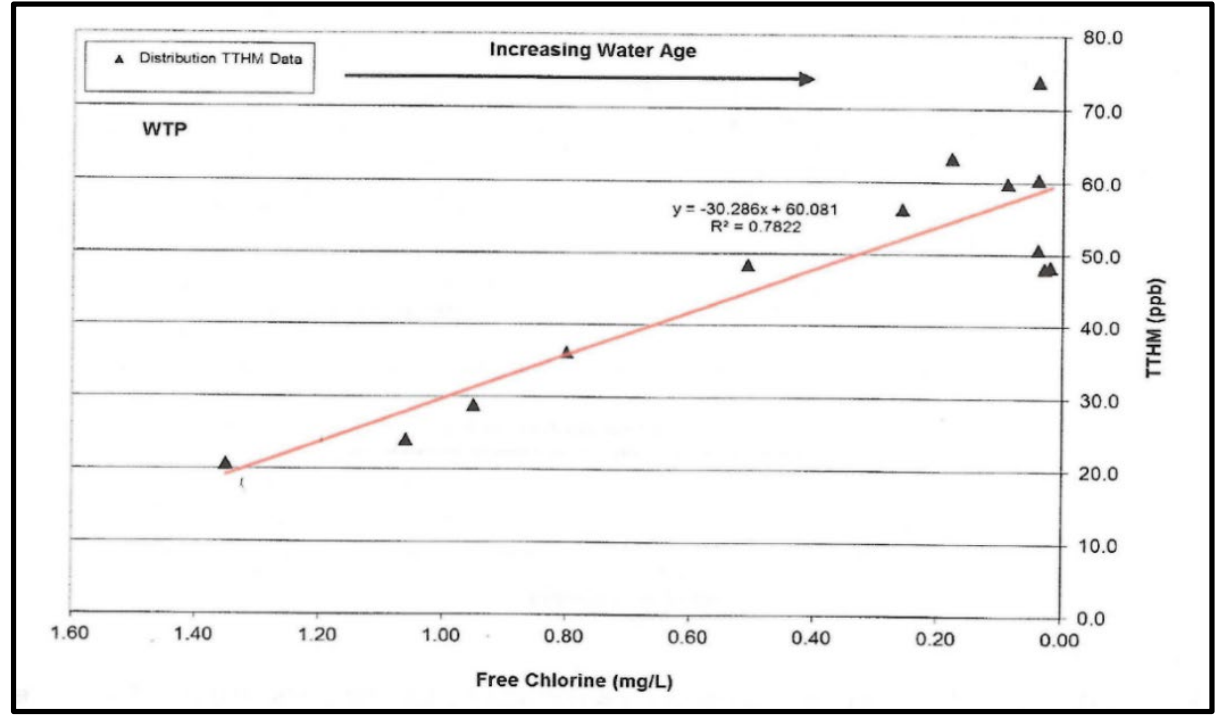

Source: AWWA 2016b.

Figure 2-4. Correlation between water age (disinfectant residual as free chlorine) and Haloacetic Acids (HAA5) regulated disinfectant byproducts (USEPA 2013).

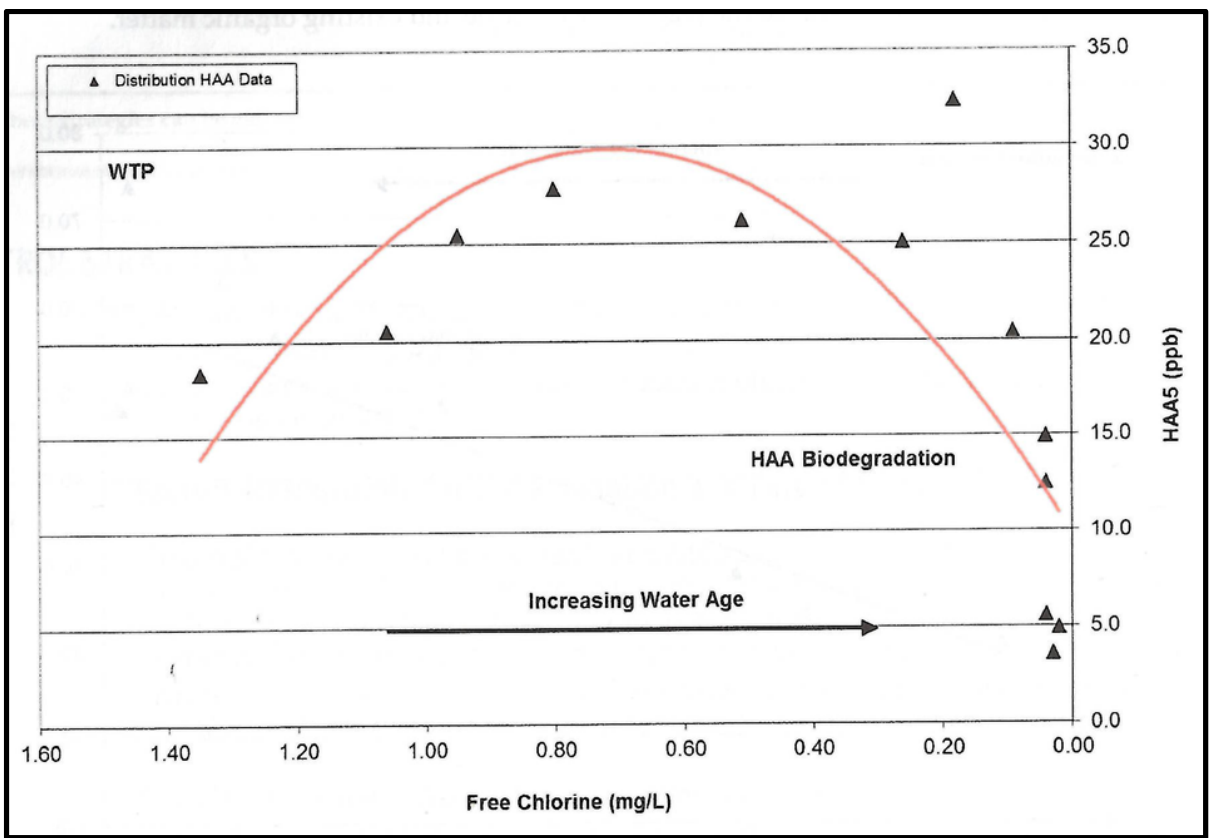

Source: AWWA 2016b. 


\subsubsection{High nitrates}

Nitrate formation in the distribution system is essentially a function of water age and stagnation in systems that use chloramine disinfectant (AWWA 2017b). When nitrification episodes occur, similar to disinfectant byproducts, the water in the lines should be removed and replaced with fresh finished water. While flushing is considered the most effective response to nitrification, other water system actions are available (Figure 2-5).

\subsection{Fire protection measures}

Although there are exceptions, the potable drinking water distribution system and the fire protection water distribution are commonly the same system. Assuming the two systems are the same, the same lines would be responsible for maintaining legal potable quality and for providing the appropriate quantity of water needed for firefighting. Firefighting capability is measured/maintained in two ways: (1) by ensuring that all parts of the system open and close as expected (via valve testing), and (2) by leaving the hydrants open long enough to ensure that a pre-determined amount of water and pressure will be delivered (fire flow testing). Note that fire hydrant flushing should include flush-hydrants, which are named for their location below ground (level or "flush" with the surface). Flush-hydrants, which are usually found in airfields, should be regularly tested (AWWA 2010).

Figure 2-5. Common water system actions to control nitrification from a 2004 survey.

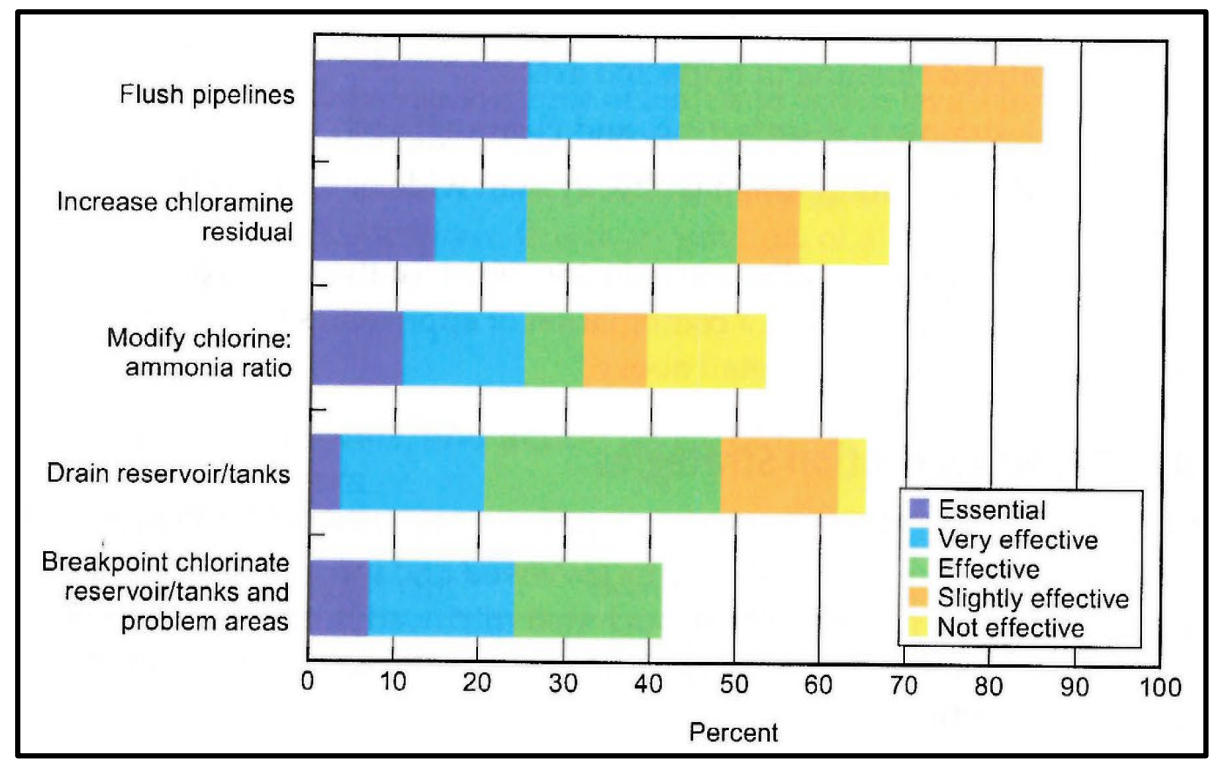

Source: Kirmeyer 2004 


\subsubsection{Fire flow testing}

Fire flow tests determine the pressure and flow-producing capacities at any point in the distribution system. Fire flow testing should be conducted every 5-10 years per location (AWWA 1989) or every 5 years as recommended by the National Fire Protection Association (NFPA) code 291 (NFPA 2016). Fire flow testing, also called main capacity flow testing, checks for the hydrants' water production ability (AWWA 1989). Hydrants are opened and tested to see if they meet their full fire flow, i.e., their ability to sustain a certain pressure for a given time period. These pressure tests confirm that the hydrant can dispense the volume of water needed to fight a fire of the size determined to be possible in that location. This can also be related to reserve waters needed for fire protection. Sometimes a storage tank is necessary to ensure that enough water is available in the event of a firefighting emergency. This flushing purpose is difficult to replace by other means; essentially flushing is the only viable option for compliance. Hydrant flow testing results can also be used in system planning for model calibration.

\subsubsection{Valve exercising}

Each distribution system hydrant and valve should be inspected annually to ensure operation. Locations in areas of freezing temperatures may want to conduct this twice per year (AWWA 1989). This inspection simply opens the valves or hydrants for a moment to prove them operational. Operating fire hydrants and valves helps to ensure that they will work properly in an emergency. In some cases, while the hydrant is open anyway, water is allowed to run until it is clear, in a combination of quality-related flushing and valve exercising. Flushing is currently the only means to truly exercise valves/hydrants. Fortunately, the quantity expelled is low relative to other flushing purposes since valve exercising only tests operation, not pressure or quantity delivered.

\subsection{Distribution system maintenance.}

Flushing is a required part of infrastructure maintenance. Essentially, pipe that has been recently worked on must be flushed to remove any contaminants introduced during construction. The aging infrastructure across the country (e.g., see Figure 2-6) makes this a potentially major flushing component. Any loss of pressure in the system will also trigger a flushing requirement and will result in a 'boil order' for any human consumption of the water. 
Figure 2-6. Old wooden water mains at Blue Grass Army Depot.

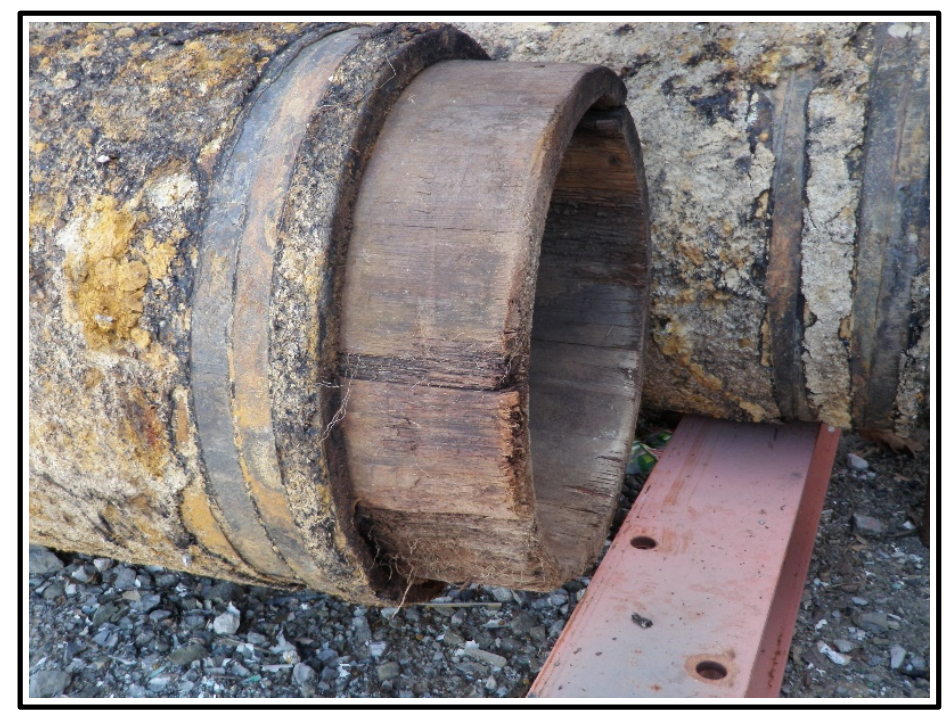

\subsubsection{Main installation}

ANSI/AWWA Standards 600-606 (AWWA 2002) address pipe installation and recommended flushing procedures. This necessary flushing is done to sanitize new materials in contact with potable water even if precautions have been taken to reduce contamination (such as sealing the ends of new sections and/or the use of high chlorine concentrated preparatory spray).

\subsubsection{Main repair (planned)}

Another potential source of contamination is through breaches in the system caused during repairs. The amount of repair work required to maintain the aging infrastructure across the United States and within U.S. Army installations is such that, at some locations, water loss from flushing following repairs can be great.

Such repairs can come in the form of pipe length replacement, or of changes from one type of pipe material to another. So, for example, it might make more sense in some repair scenarios to line a main rather than to replace it completely. This is a feasible solution to replace easily corroded ductile-iron mains, which can be lined with a cement layer that protects against corrosion and would theoretically reduce the frequency of flushing required for the removal of corroded particulates and sediments (ANSI/AWWA n.d.). In general, these replacements require the same amount of flushing (AWWA 2008b). 


\subsubsection{Main break (unplanned)}

In general, it is easier to disinfect a new main installation through repeat flushing than it is to do so with a break. The unsanitary conditions created when an existing main bursts is difficult to control (ANSI/AWWA 1993). Unfortunately, breaks are extremely common and are estimated to occur once per year per every 4 miles of pipe in the average distribution system (AWWA 2002). The leading cause of such breaks is improper installation. Breaches in the system, whether from scheduled repairs or unplanned pipe ruptures, must be followed with flushing. 


\section{Policies on Flushing}

Flushing is a tool commonly used in water distribution systems on Army installations to protect water quality and to ensure installations fire protection capabilities. To meet those goals, certain policies and regulations (at the federal, state, local, and Army level) explicitly require flushing on a routine basis. Appendix F includes a listing of federal and U.S. Department of Defense (DoD) policies. Note that the listing does not include state and local policies since this work reviewed only select regulations; many more exist at the country and global scale.

\subsection{Federal}

\subsubsection{Water quality}

The primary regulation governing water quality is the 1974 U.S. Environmental Protection Agency (USEPA) Safe Drinking Water Act (SDWA 1974). The SDWA regulates health-based standards for drinking water to protect against man-made and naturally occurring contaminants. Regulated impurities include chemicals, animal waste, pesticide, human threats, wastes injected underground, and naturally occurring substances.

The SDWA sets national enforceable contaminant levels and/or required ways to treat water to remove contaminants. Contaminants are divided into a group of primary regulations and a set of secondary drinking water standards; the second of which is non-enforceable. These secondary, nonlife-threatening contaminants include clarity, bad taste, and odor, all of which are regularly addressed by flushing.

The SDWA requires the collection of drinking water data and the monitoring of contaminants. The act also oversees state drinking water programs. The SDWA applies to public water systems that supply Army installations and to Army water systems through call-out in regulation and Unified Facilities Criteria (UFC). Monitoring or compliance is essentially maintained through the measurement bacterial counts.

Several crucial amendments have been made to the SDWA since its inception. Before 1990, water quality standards were applied at the treatment plant. In 1990, the SDWA was amended to require that water quality also be monitored at the most distant outlet of the water distribution system, 
ensuring that water quality standards apply from the water source to the tap. This amendment requires that adequate disinfection exist at the most remote point of withdrawal.

In 1996, the SDWA was amended to require that consumer confidence reports of water quality be composed and distributed to the public served. The reports provide guidance, assistance, and public information about drinking water. Water systems are also required to notify customers if any standard is not met.

In 2002, the SDWA was again amended to counter bioterrorism threats. Public Law 107-188, Public Health Security and Bioterrorism Preparedness and Response Act amended the SDWA to require Water System Vulnerability Assessments (WSVA) and Emergency Response Plans (ERPs).

Another set of federal regulations governing water quality are the Stage 1 DBP Rule (40 CFR 141-63, FR 69390, 1998) and the Stage 2 DBP Rule (40 CFR 141-71, FR 388, 2006). These rules aim to reduce exposure to DBPs by setting enforceable standards and by requiring compliance through regular monitoring. These measures of compliance include a limit on DBP formation a more stringent minimum disinfectant residual requirement.

\subsubsection{Fire protection}

There are several federal fire protection related policies. NFPA code 291, Recommended Practice for Fire Flow Testing (NFPA 2016), provides guidance on fire flow tests and marking of hydrants to determine available fire service water supply from hydrants. The code recommends that standard flushing practices for fire flow testing be conducted every 5 years to verify capacity, and that valve exercising be done annually to identify deficiencies that could be corrected to ensure adequate fire flows.

The American Water Works Association (AWWA) standards for fire protection include AWWA M17, Installation, Field Testing and Maintenance of Fire Hydrants (AWWA 1989), and AWWA M31, Distribution System Requirements for Fire Protection (AWWA 2008a). The AWWA has published standards for materials used in the field of fire protection for many decades. However, it was not until the early 1980s that AWWA's Committee on Fire Protection developed the first edition of this manual, which addresses the 
planning, design, and maintenance of distribution systems that supply water for fire protection and suppression. This manual provides guidance on the design, operation, and maintenance of water distribution systems as they relate to fire protection and fire suppression activities. When the governing body of a community makes a conscious decision to use the available water supply system for fire suppression purposes, this manual should be consulted, judiciously applied, and tempered as local conditions require. The manual is intended to help water utilities in the design and operation of their systems to maximize fire protection benefits while delivering safe, potable water to customers. Note that this manual emphasizes public water systems rather than water systems exclusively designed for fire protection. Also, users should note that this manual does not reproduce material available elsewhere in AWWA publications such as Manual M17, Installation, Field Testing, and Maintenance of Fire Hydrants (AWWA 1989), Standards C502, Dry-Barrel Fire Hydrants (AWWA 2014a), and Standards C503, Wet-Barrel Fire Hydrants (AWWA 2006).

The adequacy of a water distribution system for fire protection depends on the fire flows required. Chapter 1 of AWWA M31, Distribution System Requirements for Fire Protection (AWWA 2008a) describes several methods for determining required fire flows. Once fire flow requirements are determined, these are added to the other water system demand requirements. Chapter 2 discusses the impact of fire protection on distribution system design. Chapter 3 focuses on distribution storage in terms of both sizing and location. Chapter 4 discusses reliability issues arising because systems must remain in operation even when individual components are out of service. Chapter 5 describes fire suppression sprinkler systems and their effect on water requirements, particularly because they affect how water is used for firefighting.

Appendix A of AWWA M17, Installation, Field Testing and Maintenance of Fire Hydrants (AWWA 1989) lists organizations involved in fire protection and describes the organizations and their roles. Appendix B describes the relationship between the water supply system and fire insurance ratings, because one benefit of supplying needed fire flow is an improved fire insurance rating for a community. 


\subsection{Department of Defense}

\subsubsection{Water quality}

Army Regulation 420-1 (HQDA 2008) provides policies governing the operation, maintenance, and repair of water supply systems. Installations are required to prepare a Water Resource Management Plan to include an effective water conservation program. Violations of the SDWA will be reported using the Army Compliance Tracking System. This regulation also requires new and repaired water mains, storage tanks, wells, and equipment to be disinfected in accordance with AWWA standards C651 (ANSI/AWWA 1993), C652-92 (ANSI/AWWA 1992), C653-13 (AWWA 2013), and C654-13 (ANSI/AWWA 2013), following construction, repairs, installation of taps, or contamination situations.

UFC 3-230-01, Water Storage, Distribution, and Transmission (USACE et al. 2014) offers recommended design guidelines for the distribution system. Design often determines the frequency and location of flushing programs attempting to eliminate stagnant water.

UFC 3-230-02, Operation and Maintenance: Water Supply Systems (USACE et al. 2001) recommends that flushing for sediment removal be done annually in a unidirectional way or in a way that provides adequate scouring velocities. The UFC also suggests that dead ends be flushed, minimally, once a year, and that flushing in response to odor or taste complaints be done as needed.

\subsubsection{Fire protection}

UFC 3-600-01, Fire Protection Engineering, Standard (USACE et al. 2013) applies to planning and development projects and to the design construction and commissioning documents used for the procurement of facilities. Primary fire protection criteria reference design-bid-build and design-build contracts. This UFC specifies rules related to hydrant capacity for a given number and size of structures, which determine the capacity of the distribution system. The UFC also includes a requirement that fire departments perform annual fire flow testing (U.S. Army 2009).

UFC 3-601-02, Operation and Maintenance: Inspection, Testing, and Maintenance of Fire Protection Systems pertains to the inspection, testing, and maintenance of engineered fire protection features in DoD facilities. The UFC includes the mandate for WSVAs and ERPs, and lists flushing as a common task for use in inspection, testing, and maintenance. 


\subsection{Select state guidelines}

State guidelines related to flushing vary across the country. The following paragraphs include examples of state laws that would require installation compliance. Many state guidelines reference (or simply echo) the requirements of federal law. Other state laws adopt more restrictive regulations based on the state's specific goals (usually originating from state's department of public health or the state's interpretations of the SDWA).

California, for example, has state-specific flushing requirements in accordance with the California Safe Drinking Water Plan. One California utility, the Western Municipal Water District (WMWD 2016a), informed its residents that their water system flushing program helps to maintain high quality water throughout their service area and that flushing operations are required on a regular basis by the California Department of Public Health (WMWD 2016b).

In the state of Florida, public water suppliers that claim to provide fire protection are required to have finished water storage tanks or reservoirs with sufficient capacity for fire prevention (FRWA 2012) even though they are not required to make any such claim. This regulation is important because it attempts to control the amount of storage, which is known to have a great impact on flushing requirements if supply exceeds demand.

\subsection{Select local guidelines}

In some locations, even more location-specific regulations related to flushing exist beyond federal, state, and Army policy. Installations should be aware of and consider county-level regulations (within the United States), or host countries regulations (outside the United States) when optimizing flushing.

An example of country specific law can be seen in Italy where water rights and infrastructure ownership are highly contested issues (Caporale 2015). Such issues can complicate distribution system maintenance and subsequent flushing programs by adding a layer of compliance. In Italy, U.S. installations must be sensitive to local requirements and thoroughly investigate local laws when planning, developing, and implementing a flushing program.

Some contracts between Army installations and the local governments or private utility contractors may require flushing protocols not specified 
elsewhere in criteria or regulation. For example, Fort A.P. Hill conducts fire flow testing annually opposed to the standard of about every 5 years. ${ }^{*}$

Additionally, area-specific water withdrawal permits may be in place in some locations. This limitation on withdrawals has a great influence on the operation and maintenance of the distribution system and essentially holds the utility more accountable for water-conserving usage. However, it is possible for the installation to be exempted from the permitting law, which in turn would provide little incentive for conservation. This is exemplified in a part of the state of Virginia where groundwater withdrawal permits are required for all facilities east of interstate 95. Even though Fort A.P. Hill is located east of the highway, the installation is exempted from permitting. ${ }^{\dagger}$

* Personal communication between Victoria Heath, ERDC-CERL and Gary Manville. Fort A.P. Hill, Virginia, 2018.

† Personal communication between Victoria Heath, ERDC-CERL and Gary Manville. Fort A.P. Hill, Virginia, 2018. 


\section{Potable Distribution System Flushing Methods}

Flushing is recommended at several stages of the distribution system's life

- initially after installation (per AWWA C60o-93 [AWWA 1993])

- as needed after install for scouring and water quality control (per AWWA C652-92 [ANSI/AWWA 1992] and AWWA C651-92 [ANSI/AWWA 1993])

- if repair or maintenance to the pipe is ever needed (Environmental Protection Agency)

- annually for hydrant inspection

- every 5-10 years for hydrant flow testing (AWWA 1989, NFPA 2016).

The many possible purposes for flushing can make it a challenge to develop a comprehensive program. However, a comprehensive plan is key to an efficient and water-conserving flushing operation. This objective (to achieve efficient and water-conserving flushing operation) should drive the plan creation (Martin and Ries 2014). The following sections describe common approaches to flushing programs.

\subsection{Conventional}

Conventional flushing, sometimes called reactionary hydrant flushing (Reiss et al. 2010), involves opening just a few specific hydrants, usually in no determined order for an indeterminate amount of time. Flushing of this type is typically conducted in response to a customer complaint or on a loose annual basis. In either case, hydrants are typically opened and left to run until the water appears clear and color visibly improves. The velocities achieved in conventional flushing are not usually sufficient to remove loose pipe deposits (Reiss et al. 2010). Conventional flushing promotes water replacement but does not generally result in scouring (Mercer 2010). In conventional flushing, no valves are closed to increase velocity (Martin and Ries 2014). Conventional flushing requires as much as $40 \%$ more water than does unidirectional flushing (Boulos et al. 2006). As water conservation has been prioritized over the last few decades, localized conventional flushing is used more commonly as a response to quality test failures or customer complaints than as a method for annual flushing. The use of conventional flushing is not favored as part of a routine or annual program on the system wide scale because the practice has many disadvantages. 


\subsection{Unidirectional}

Unidirectional flushing (UDF) is a systematic approach to flushing that involves specific design sequences (Reiss et al. 2010). In this case, the entire distribution system or sub network (loop division) is flushed from the clean water source out to periphery of the distribution network. This directional flow keeps debris that is being removed from re-entering a clean stretch of system. UDF achieves higher velocities, between 5-10 feet per second (Reiss et al. 2010), enough to scour and remove biofilms and/or sediments.

This type of systematic approach requires the development of a plan or program that will likely need to be revised every year or so. The program is developed from a hydraulic modeling of the distribution system. An engineer can use a current model of the distribution system assets to isolate pipe segments of interest by valve closing to achieve the desired pipe velocities (Reiss et al. 2010). This often requires more upfront time (Mercer 2010).

In UDF, after the valve sequence has been established, flushing time is usually based on the removal of two to three volumes of water. However, visual inspection usually takes final precedence. If discoloration persists after the pre-determined length of time for volume removal, field crews may need to extend flushing times. UDF success in a city case study showed an $85 \%$ reduction in iron, 32\% increase in chlorine residual, $75 \%$ drop in turbidity, and $78 \%$ reduction in complaints after UDF was performed, relative to conventional flushing alone (Reiss et al. 2010).

\subsection{Automatic flushing systems}

Automatic Flushing Systems (AFSs, see Figure 4-1) can be used when velocities (to achieve a scouring effect) are not of concern and when the flushing purpose is simply for water turnover. AFSs can be used in two ways: as continuous blow-off points that are essentially always flushing, or as periodic flushes programed on a daily/weekly/as-needed basis. This is considered a short term (preventive) strategy (Boulos et al. 2006). Automatic flushing can optimize flushing water consumption because regular periodic flushes can be smaller than manual flushes (Mercer 2010). Automatic flushers are often employed at dead ends in the system or in areas of low demand. AFSs essentially take the place of looping the infrastructure or creating an artificial demand. 
Figure 4-1. Automatic flusher at Blue Grass Army Depot.

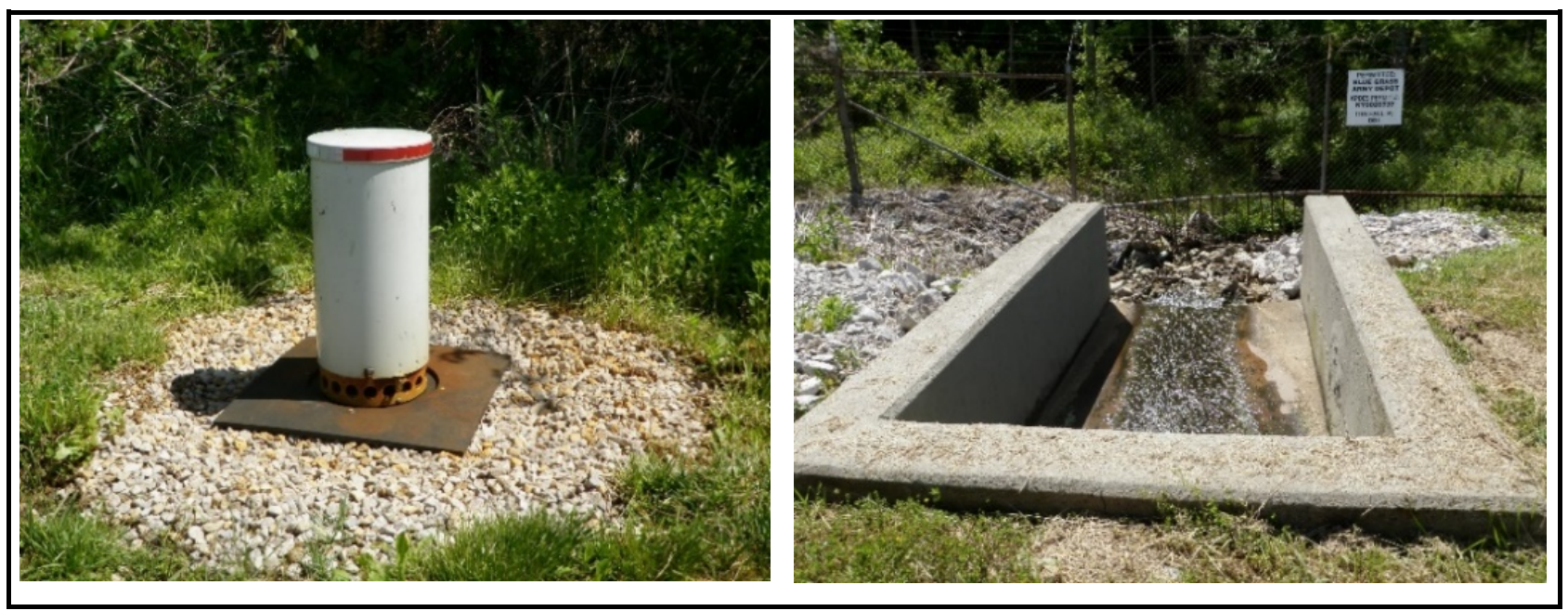




\section{Models and Tools}

Models and tools for water quantity and quality control are not only becoming more popular but more of a necessity for the sophisticated water provider. Models vary in their capabilities, but ultimately provide a greater understanding of the distribution system; some can even simulate scenarios for more proactive water management. Note that pressure and velocity within a pipe are inversely related; as one increases, the other decreases (AWWA 2016). Software that allows the user to visualize and conceptualize the system can make these types of relationships more manageable.

The hydraulic integrity of a system depends on its ability to provide a reliable supply that meets all demands by providing adequate pressure, fire protection, and uninterrupted reliability (Boulos et al. 2006). Hydraulic models are used to design distributions systems and to modify and maintain them after design. A well-modeled system can form the basis for a highly sophisticated flushing plan that optimizes flushing efficiencies. Though models can be costly, a well-chosen mode can ultimately provide an invaluable source of information and a dynamic tool that gives management more sophisticated system operation. These engineering-based models incorporate both physical and flow related characteristics of the system. Hydraulics can be modeled using Computational Fluid Dynamic (CFD) modeling.

Water quality can often be inferred from the hydraulic model. However, while the physical hydraulics of the system can be computerized and manipulated to optimize pressure and quantity, a more powerful tool would be one that incorporates the results of water quality monitoring as a means of forecasting quality issues. Knowledge of water quality parameters in reference to space and time can be used to create a tool that can help with operational management of such parameters as water age control, nitrification, mixing issues, booster chlorination, and more. This type of program could help create a maintenance schedule for flushing, tank cleaning, main repair pipeline rehabilitation, and more.

Models already in use by installations include but are not limited to: AquaGEO (formerly Aqua CAD Suite), EPANet, InfoWater, Water CAD, and Water GEMS. 


\section{Survey of Army Installations}

\subsection{Survey creation}

A questionnaire was created, based on an Illinois Section of the AWWA (ISAWWA) Flushing Survey (Appendix A). While the questionnaire was underway, the need for important changes to the survey became clear. Appendix B contains the original project survey. Appendix C contains the final version of the project survey that was used for data analysis. Appendix $D$ lists the changes made and explains the need for those changes. Appendix $\mathrm{E}$ lists the compiled survey results.

\subsection{Survey administration}

The survey was administered to 156 Army installations (Forts, Arsenals, Depots, and Ammunition Plants) by telephone and email to characterize the flushing protocols and to determine the significance of flushing programs to installation water demand and to water loss. Installation fire personnel were consulted as needed (most often by the installation water utility point of contact) to complete the installation survey.

About $18 \%$ of the 156 surveyed Army installations completed the questionnaire. An additional 9\% partially completed the survey with some amount of useful information. Of these, 11 installations were chosen to serve as case studies
1. Fort Hood, Texas
2. For Leonard Wood, Missouri
3. Fort Bragg, North Carolina
4. Fort George Meade, Maryland
5. Fort Greely, Alaska
6. Fort Irwin, California
7. Fort Buchanan, Puerto Rico
8. Fort Benning, Georgia
9. Fort A.P. Hill, Virginia
10. Fort Huachuca, Arizona
11. Fort Carson, Colorado.

Responses to the completed surveys were transcribed. In some cases, the surveys elicited more in-depth views of particular installations, which 
highlight common flushing problems that installations experience as well as innovative solutions that minimize water loss. These data were graphed and then used to infer correlations between flushing protocols across multiple installations, and to assess the various flushing programs.

\subsection{Review of findings}

\subsubsection{Quantity of potable water used for quality and fire flow flushing vs. population and flushing percent}

Figure 6-1 shows the results from the 28 completed questionnaires. The $\mathrm{x}-$ axis shows each response in increasing ordered of population density (from population 850 to 200,000). The blue line represents the number of gallons flushed per year for the purposes of water quality maintenance. The red line represents the number of gallons flushed per year for the purposes of fire flow testing. The left-hand-side y-axis shows gallons (from o to 180 million). The right-hand-side y-axis shows percent of total water consumed and the green bars represent the percentage of total water consumed at an installation that is consumed by flushing (including both quality and fire flow flushing).

The trends show that, at installations with small populations (less than 11,00o), the percentage of water flushed for water quality maintenance and for fire flow testing is relatively low in comparison with those same average values for installations with populations greater than 11,000. Also, the percentage water flushed in relation to total water used is larger at installations with greater populations.

The results also clearly show that, since the blue line is almost always above the red line, flushing for water quality maintenance uses much more water than does flushing for fire flow testing. This is further illustrated in the outlier installations (populations of 31,000), where flushing for water quality maintenance is over three times that of flushing for fire flow testing. Figure 6-2 shows a more detailed view of the same information, excluding the outliers. These data show that flushing on average accounts for about $1.67 \%$ of total usage. The high flushing percentage at the two outlier installations is further discussed in section 6.4, "Case studies." 
Figure 6-1. Quantity of potable water used for quality and fire flow flushing vs. population and flushing percent.

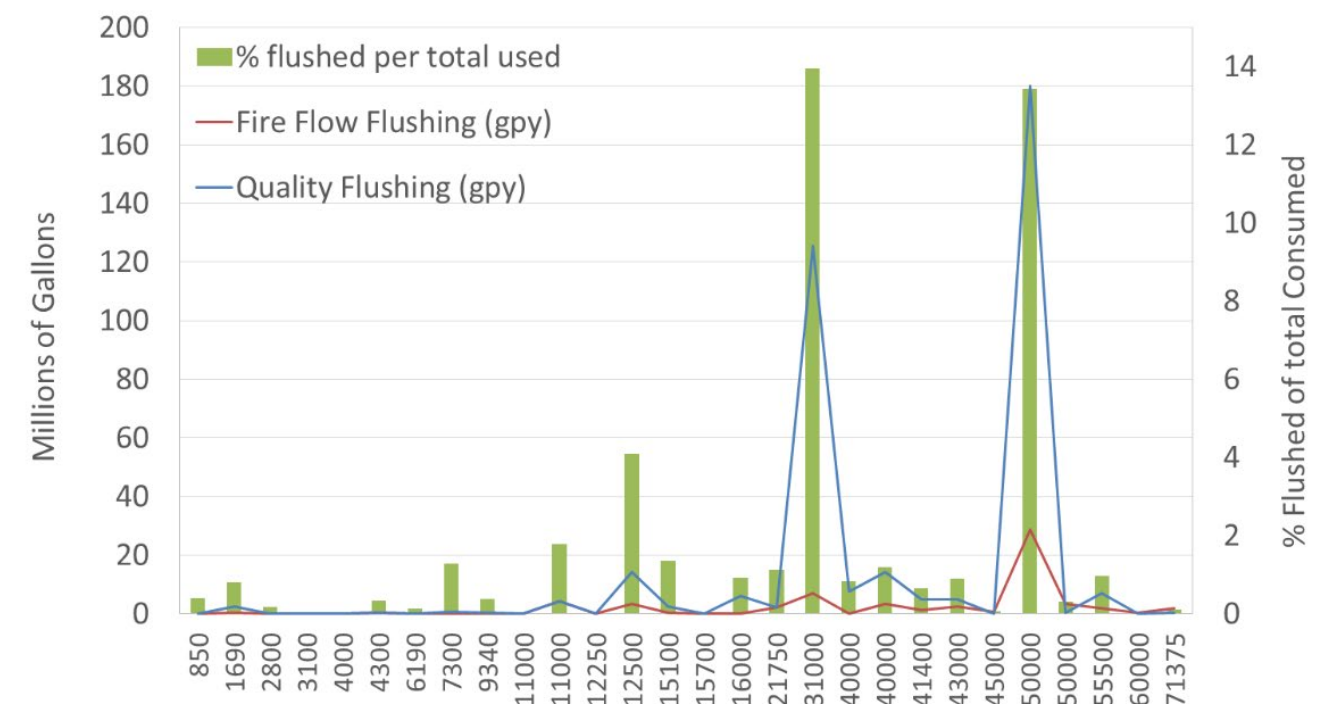

Installation Population

Figure 6-2. Quantity of potable water used for quality and fire flow flushing vs. population and flushing percent excluding outliers.

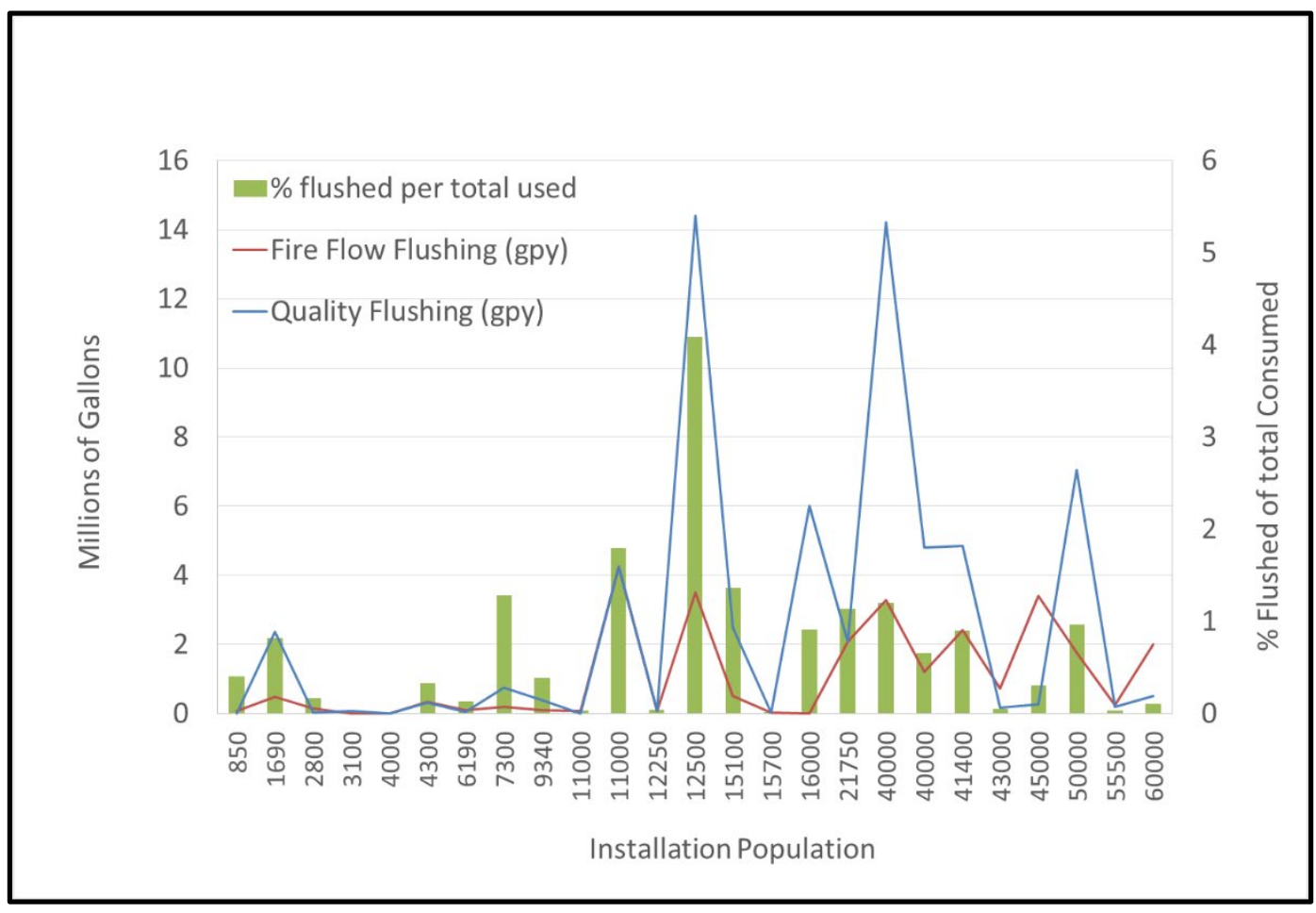




\subsubsection{Effect of management and source water on flushing program frequency}

Figure 6-3 (left) shows three bars representing source water for an installation: groundwater, surface water, or combination. After installations were divided into groups based on either source water or management, the frequency that each group flushed their systems was examined. Figure 6-3 (right) has three bars representing the operating system at the installation: contractor owned and operated (COCO), government-owned contractoroperated (GOCO), or government-owned and operated (GOGO).

The frequency at which flushing programs were being conducted ranged from only as needed (less than annually) to daily. Installations that used surface water as a water source seem to require the greatest amount or frequency of flushing. In general, $\mathrm{COCO}$ and GOCO installations used more detailed flushing protocols that varied in frequency depending on a number of factors. This contrasts with GOGO systems, which generally used a single type of annual program, which may indicate a lack of flexibility.

Figure 6-3. Flushing frequency divided by resources management type (left) and flushing frequency by source water (right).

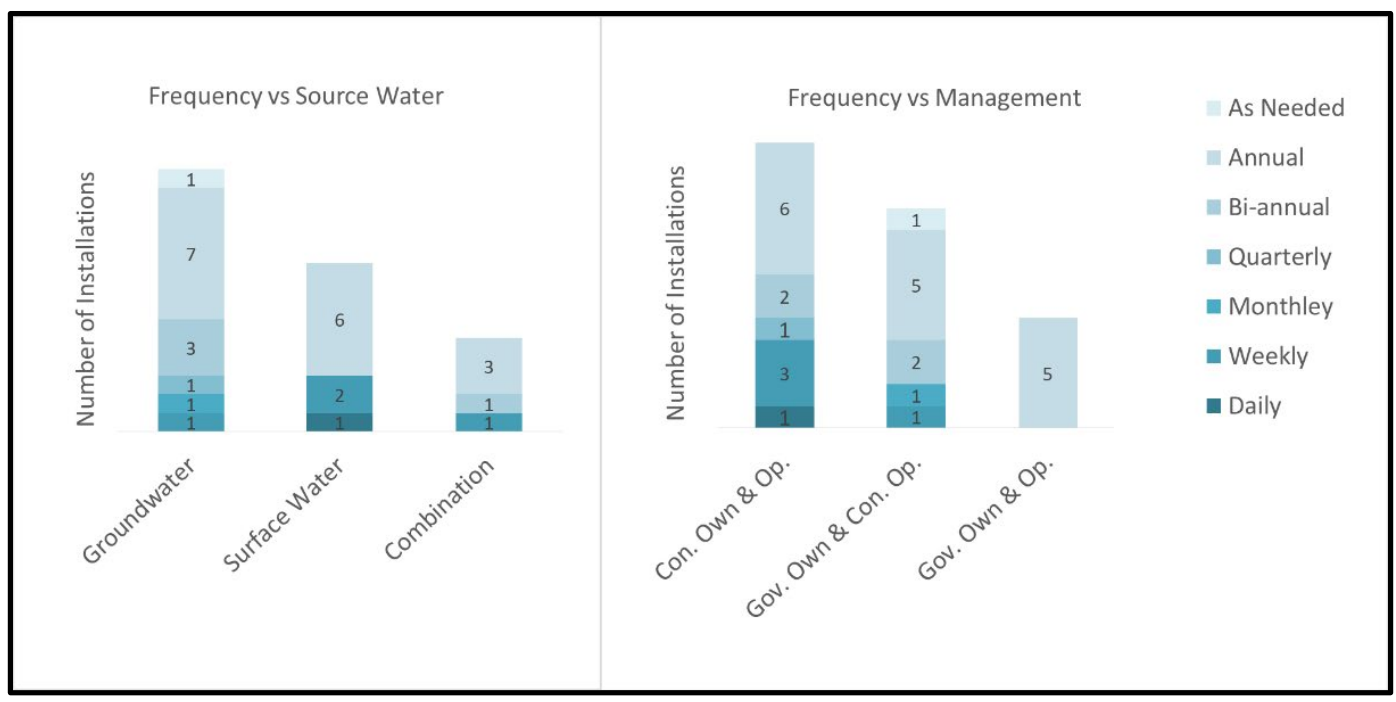

\subsubsection{Effect of management and source water on flushing duration deciding factor}

The length of time to flush (duration) is generally based on one of four factors: (1) a visual inspection for clarity, (2) a specified amount of time to flush, (3) a specific volume of water to be removed by flushing, or (4) a measurement of improved chlorine residual,. 
The simplest criterion is visual inspection. Flushing at fixed intervals of time may be based on an arbitrary length of time, or on specific time measure specified by a model program. Flushing based on volume-based measurements are usually based on a sophisticated, calculated choice made by a model program. Flushing based on chlorine residual measurements could be based on a sophisticated constant chlorine measurement taken at an auto-flusher, or on a simple field test conducted as flushing occurs.

The data in Figure 6-4 show that neither source water nor management type correlate with a single specific deciding factor for flushing duration. Instead, roughly $50 \%$ of installations were flushing for a duration based on chlorine residual improvement. Most others use a classic visual inspection while a small percentage flush based on either time or volume passed.

\subsubsection{Effect of management and source water on flushing reason}

The data in Figure 6-5 also show that neither source water nor management type correlate with a single specific reason for flushing. Instead, about $50 \%$ of systems are flushed for the purposes of regular maintenance (perhaps mandated by policy) while the other 50\% are flushed to maintain chlorine residuals or essentially to maintain water quality (usually in response to water age).

Figure 6-4. Flushing duration factor divided by resources management type (left) and flushing duration factor by source water (right).

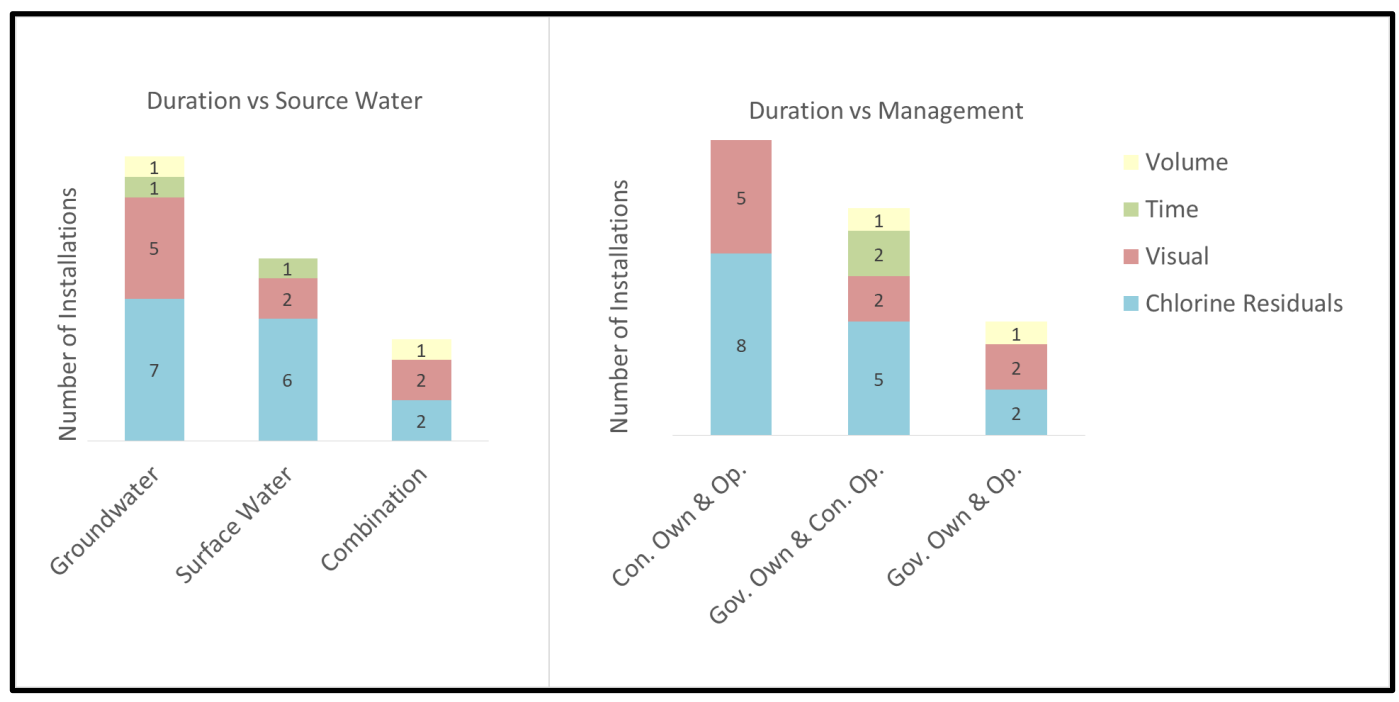


Figure 6-5. Flushing reason divided by resources management type (left) and flushing reason by source water (right).

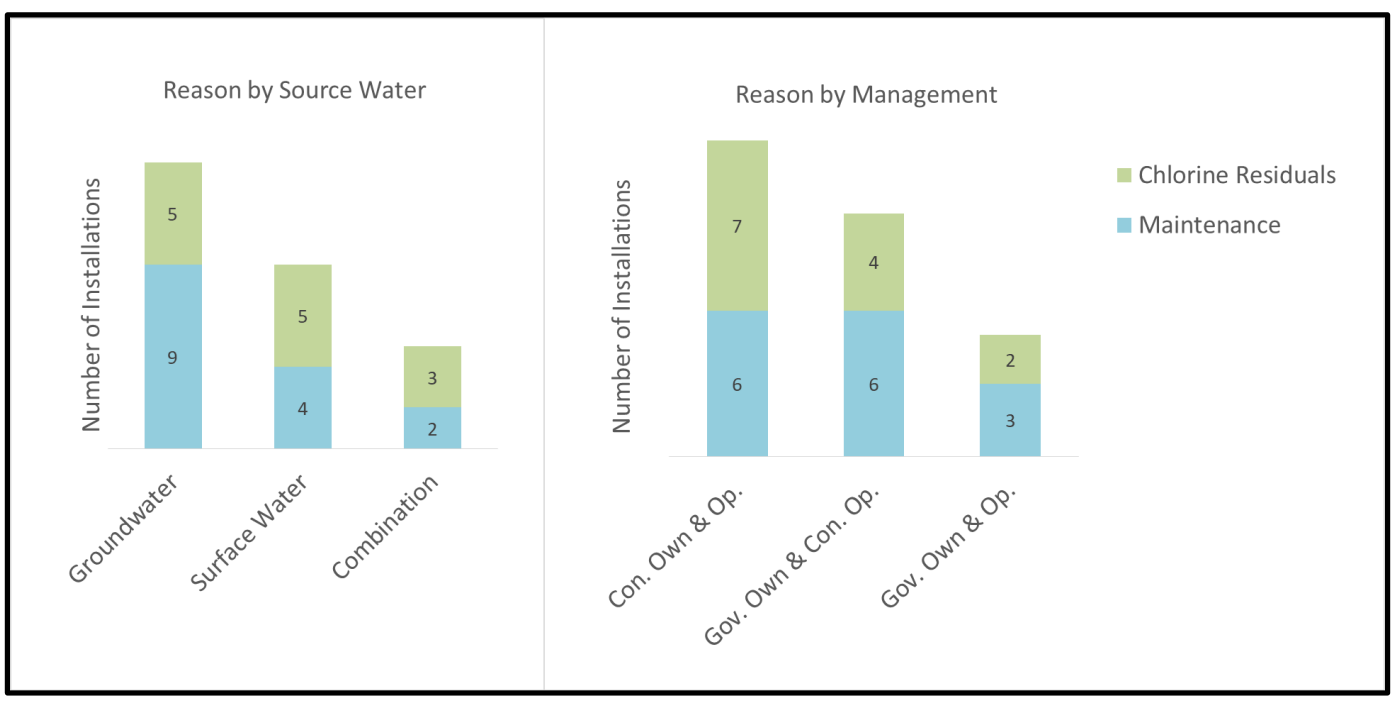

\subsection{Case studies}

Army installations are motivated to address water quality anomalies to meet regulatory requirements and to respond to very real human health concerns. Oftentimes the quick solution (conventional flushing to flush remove contaminants) results in large losses of highly treated potable water. The water-conserving alternative, to either address the underlying causes of compromised water or to make use of the volume of flushed water for nonpotable needs, requires careful planning and often a significant amount of time and cost in engineering. The following sections give some prime examples of issues and solutions at Army installations across the country, including the two outlier installations shown in Figure 6-1.

\subsubsection{Fort Hood, TX: Large site, high flushing (outlier), auto-flusher proposal}

Fort Hood, Texas, maintains a vital defense force; it supports multiple units, a corps headquarters, and a robust mobilization mission; and meets the training and support requirements for many smaller units and organizations (U.S. Army 2018g). Fort Hood's population is extremely large, around 50,000 , about $3 / 4^{\text {ths }}$ of which are overnight residents. The area, which is subtropical humid, can suffer from both drought and rain-induced flooding. 
Note that the information that follows was either directly calculated or collected by phone conversation and email. ${ }^{*}$

The COCO potable water distribution system is supplied by surface water with a demand of roughly 4.25 million gallons per day (MGD). Relative to the other surveyed installations, this site has a large population and a high level of consumption. Their percentage flushed of over $13 \%$ of total usage (as reported in the questionnaire) is also extremely high. This amount of water flushed is far more that of the other installations; as such, Fort Hood is one of the two outliers. This could be attributed to the fact that the existing water main sizing was based on fire flow needed to meet mission needs. This presents a unique issue in that the installation does not have adequate demand to balance out capacity due to the needs to meet fire flow (e.g., airfields, ammo storage points, loading and unloading points, rail yard).

As a result, flushing at Fort Hood is conducted weekly using auto-flushers. Frequent routine flushing is conducted to remove old water and to keep up chlorine residuals. The installation has already proposed optimization strategies that include the installation of seven new automatic flushing units at dead-end or critical locations. Since the installation of additional automatic flushing units alone is not likely to greatly reduce the total amount flushed, other alternatives for water age management should be considered at this installation.

\subsubsection{Fort Leonard Wood, Missouri: Large site, high flushing (outlier)}

Fort Leonard Wood, Missouri, supports a range of military operations, including the training of warriors/leaders with unique skills and tools developed at the Maneuver Support Center of Excellence, including total Army Engineer, Chemical, Biological, Radiological, and Nuclear (CBRN), Military Police, and Maneuver Support capabilities (U.S. Army 2018i). Fort Leonard Wood is a large site that serves a population of around, 31,000 over $3 / 4^{\text {ths }}$ of which are overnight residents. The area, which is subtropical humid, can suffer from both drought and rain-induced flooding. Note that

\footnotetext{
* Personal communication between Victoria Heath, ERDC-CERL and Chad Reynolds, American Water, Fort Hood, Texas, 2018.
} 
the information that follows was either directly calculated or collected by phone conversation and email. *

The GOCO potable water distribution system at Fort Leonard Wood is supplied by a combination of surface and groundwater. The demand is roughly 2.6 MGD. Relative to the other surveyed installations, this site has a mediumto large-sized population and consumption level. It is not immediately clear why Fort Leonard Wood flushes such a large amount of water, but the percentage flushed, almost $14 \%$ of total usage, is very high and makes this site an outlier. Most of the flushing is conducted to control water quality and low chlorine residuals. It is recommended that the site consider improving its water age control and employing BMPs that save flushed water.

\subsubsection{Fort Bragg, North Carolina: Large site and low flushing}

Fort Bragg, North Carolina, equips, trains, rapidly deploys, and sustains full spectrum forces (U.S. Army 2018c). Fort Bragg is one of the largest military installations in the world; it supports an average daily population of over 45,000 , almost $3 / 4^{\text {ths }}$ of which are overnight residents on site. Relative to the other surveyed installations, this site has a large population and a high level of consumption. Fort Bragg occupies an area of around 163,000 acres northwest of Fayetteville, North Carolina. The area, which is subtropical humid, can suffer from both drought and rain-induced flooding. Note that the information that follows was either directly calculated or collected by phone conversation and email. ${ }^{\dagger}$

The COCO potable water distribution system at Fort Bragg is operated by Old North Utility Services and American States Utility Services. The water supply is a combination of ground and surface water (Cape Fear River Basin). The demand is approximately 4.5 MGD.

Since Fort Bragg has such a large area, one would expect there to be deadend distribution lines that would need flushing (perhaps excessively to maintain chlorine residual). However, less than half of $1 \%$ of total water consumption is used for the purposes of flushing, which places Fort Bragg among the lowest out of all installations surveyed. Flushing at Fort Bragg is conducted weekly using automatic flushers, mainly to maintain chlorine

* Personal communication between Victoria Heath, ERDC-CERL and Keith Pendleton. Fort Leonard Wood, Missouri, 2018.

† Personal communication between Victoria Heath, ERDC-CERL and Darryl Butler, Fort Bragg, North Carolina, 2018. 
residuals. Areas of chronic low chlorine residuals either have their routine flushing schedule increased or they have an automatic flusher installed at the location. Before this strategy was adopted, flushing frequency increased in response to elevated levels of DBPs. The system now meets regulatory limits and DBP levels are no longer a quality issue. The system also undergoes an annual chlorine burn to reduce biofilm growth.

In the past, the water distribution system experienced problems of tuberculation. This was a frequently noted issue when American States Utility Services first took over operation, but it has been dramatically reduced due to a new rigorous flushing and maintenance program. The current flushing program opens the hydrant for a duration of time based largely on visual inspection, but also possibly based on chlorine readings or on a standard flushing time of $15^{-20}$ minutes. The system is modeled, and the model is presumably used to improve and edit the flushing program. Fort Bragg has combined a regimen of automatic flushing and a continuous revision of the flushing protocol to maintain their percentage of water flushed of the total water used at $0.01 \%$.

\subsubsection{Fort George Meade, Maryland: Use of Neutral Output Elimination System (NO-DES)}

Fort George Meade, Maryland, is the Nation's Center for Information, Intelligence, and Cyber Operations. It has a large daily population, near 55,500 , almost half of which are overnight residents on site. The Fort is located south of Baltimore in Maryland. The area, which is temperate, can suffer from both drought and rain-induced flooding. Note that the information that follows was either directly calculated or collected by phone conversation and email.*

The COCO potable water distribution system at Fort George Meade is owned and operated by American Water. In the past, the installation operated solely on surface water, but it became too costly to treat the water supply. Currently, the water supply is fed by groundwater though six wells in a confined aquifer. The demand is roughly 2.5 MGD. Relative to the other surveyed installations, Fort George Meade has a large population and a fairly high level of consumption. The installation's large area, around 13,500 acres, would lead one to expect dead-end distribution lines that would need

\footnotetext{
* Personal communication between Victoria Heath, ERDC-CERL and Beth Grosscup, Fort George Meade, Maryland, 2018.
} 
flushing. In fact, about $1 \%$ of total water consumption is used for flushing, which is toward the high end of average out of all installations surveyed.

Fort George Meade's conducts some flushing daily using automatic flushers, mainly to maintain chlorine residual levels. Whole system unidirectional flushing is conducted annually. Bi-annual flushing is not an option in this aged system, which is too worn out to withstand such pressure twice yearly). In areas of chronic low chlorine residuals, either the routine flushing schedule is increased or automatic flushers are installed.

Part of the installation's water distribution system had recently been replaced in an area with failing mains. After the replacement, there were many complaints about sand in the lines. American Water, the utility privatization contractor, used the NO-DES technology described below for flushing out the lines. NO-DES normally requires flushing until a certain desired drop in pressure is achieved. In water scarce areas, flushing is conducted for a specific number of gallons.

Compared to conventional flushing, which flushes through a 4-in. opening with a diffusor attached for various periods of time, NO-DES saves a considerable amount of water. Instead, NO-DES technology uses hoses attached to the 2.5-in. opening that connect back to the truck's filtration system. Water is pumped out of the system, through the filters, and back into the system. This method allows water to pass through the pipes at higher velocities, which enables a better scour of the pipes themselves. The equipment measures pressure, velocity, and discharge, which shortens the time required by flushing. Moreover, the NO-DES computer software shows the exact amount of water flushed from each hydrant. NO-DES technology can also be used for unidirectional flushing and the company is currently investigating its capabilities for fire flow testing. Its benefits to conservation can be seen in Figure 6-6.* Appendix I includes a more detailed description of the system.

After a successful "spot" flush using the filter truck, the installation decided to conduct its annual flush with NO-DES in the Fall of 2018. It is anticipated that the NO-DES technology will save a minimum of 4 million gallons from flushing annually at an estimated cost savings of $\$ 37,000$. The current flushing program opens the hydrant for a duration of time based largely on

*Personal communication between Victoria Heath and Beth Grosscup. Fort George Meade, Maryland, 2018. 
chlorine readings, but also (possibly) based on visual inspection for clarity. The system is modeled using Water Gems by Micro-station, which is presumably applied to improve and edit the flushing program. To summarize, Fort George Meade has tested and is now using a new flushing technique that they have estimated will save money over time.

\subsubsection{Fort Greely, Alaska: Small size and low flushing}

Fort Greely, Alaska, serves as the primary support base for a host of tenants that support the Ground-based Midcourse Missile Defense initiative. The main component support is the Alaska National Guard, whose key mission is security and operation of the Missile Defense Site. A small regular Garrison unit is charged with oversight of the installation and main cantonment areas (U.S. Army 2018f). Fort Greely has one of the smallest populations of the surveyed installations with a daily population under 1000. The Fort is located south-east of Fairbanks, Alaska. Its 7,200-acre area, which is subarctic, can suffer from both drought and rain-induced flooding. Note that the information that follows was either directly calculated or collected by phone conversation and email.*

Fort Greely's COCO potable water distribution system is supplied by a 300 $\mathrm{ft}$ well. The system serves an average daily population of 850 individuals, 250 of which are overnight residents on site. The demand is roughly 45,000 gallons per day. The site also has a significant aboveground storage (288,o0o gallons), mainly for fire suppression. This large quantity of water is maintained through in-tank chlorination and recirculation. At just around $0.4 \%$ of total usage going to flushing, this site is typical of small population installations that keep flushing levels under $1 \%$ of total usage simply by maintaining a relatively up-to-date distribution system and plan.

\subsubsection{Fort Irwin, California: Arid climate and regular flushing}

Fort Irwin, California, which serves as a major training area for the U.S. military, is a census-designated place located in the Mojave Desert in northern San Bernardino County, California. The 4,500 acre site is located in an arid low-precipitation climate and consequently must be especially aware of its water consumption. Fort Irwin's GOCO water distribution system serves about 1.8 MGD to about 16,000 individuals, over half of which

\footnotetext{
* Personal communication between Victoria Heath, ERDC-CERL and AI Thomas, Doyon Utilities, Fort Greely, Alaska, 2018.
} 
are overnight residents. Note that the information that follows was either directly calculated or collected by phone conversation and email. ${ }^{*}$

\subsubsection{Fort Buchanan, Puerto Rico: Small site, low flushing, and non- potable supply}

Fort Buchanan, Puerto Rico, which provides military services to the entire Caribbean region and to Central and South America, supports a diverse community of strong and resilient Soldiers, civilians, families, and partners (U.S. Army 2018d). Fort Buchanan is a small to moderate sized installation that serves a population around 4,000 , over $3 / 4^{\text {ths }}$ of which are overnight residents. The 700-acre area, which is tropical humid, can suffer from both drought and rain-induced flooding. Note that the information that follows was either directly calculated or collected by phone conversation and email. ${ }^{\dagger}$

Fort Buchanan's COCO potable water distribution system is supplied by surface water. The demand is roughly 300,000 gallons per day. Relative to the other surveyed installations, this site is small by area, population, and level of consumption. The percentage of water flushed is very low, less than $0.01 \%$. This is attributed to a very sophisticated unidirectional flushing program, which was produced for the Fort by the regional Public Health Command (PHC) in 2013 using reimbursable funds.

\subsubsection{Fort Benning, Georgia: Large population, high flushing, and auto- flushers}

Fort Benning, Georgia, and the Maneuver Center of Excellence provide trained and combat-ready Soldiers and leaders; develop the doctrine and capabilities of the Maneuver Force and individual Soldier; and provide a world class quality of life for Soldiers, civilians, and Army families to ensure that the Army's Maneuver Force remains the world's premier combat force ready to "Win in a Complex World." (U.S. Army 2018b). Fort Benning is a large installation that serves a population around 40,000, over $3 / 4^{\text {ths }}$ of which are overnight residents. The 182,000 -acre area, which is subtropical humid, can suffer from both drought and rain-induced flooding.

\footnotetext{
* Personal communication between Victoria Heath, ERDC-CERL and Christopher Woodruff, Fort Irwin, California, 2018.

† Personal communications between Victoria Heath, ERDC-CERL and Anibal Negron, Fort Buchanan, Puerto Rico, 2018; and Steven Golub, U.S. Army Public Health Command (USAPHC), Fort Sam Houston, Texas, 2018.
} 
Note that the information that follows was either directly calculated or collected by phone conversation and email. ${ }^{*}$

Fort Benning's COCO potable water distribution system is supplied by surface water. The demand is roughly 4 MGD. The installation's percentage flushed is slightly high at about $\mathbf{1 . 2 \%}$. Although its consumption and population are high, the installation can maintain reasonably low flushing levels percentage, which may be attributed to the use of sophisticated auto-flushers. The flushers constantly measure water quality data, which are used to determine flushing time and length. This highly individualized approach minimizes unnecessary flushing and flushes only when there is need.

\subsubsection{Fort A.P. Hill, Virginia: Use of Fire Flow Pro}

Fort A.P. Hill, Virginia, a Regional Training Center, provides training enablers to support contingency operations in the mid-Atlantic and National Capital regions (U.S. Army 2018a). The 77,600-acre area installation, which is subtropical humid, can suffer from both drought and rain-induced flooding. Note that the information that follows was either directly calculated or collected by phone conversation and email.

Fort A.P. Hill's COCO potable water distribution system is supplied by groundwater. Although specific population and flushing data were not available at this location, it was noted that the installation makes innovative use of Fire Flo Pro. This product, detailed in chapter 7, is used in their fire flow testing to reduce the quantity of water flushed while still maintaining testing integrity. The data shown in Figure 6-6 indicate that Fort A.P. Hill's monthly flushing (in gallons) fell tremendously over time as a result of switching to the Fire Flow Pro diffuser system, which allowed the site to switch from a 4.5-in. nozzle to a 2.5 -in. nozzle. Additionally, the Fire Flow Pro also allows one person to perform the hydrant flow tests saving manpower.

\subsubsection{Fort Huachuca, Arizona: Large site and arid climate}

Fort Huachuca, Arizona, develops and tests command, control, communications, computers, combat systems, intelligence, surveillance and reconnaissance capabilities; delivers intelligence and unmanned aircraft systems training and education; designs, develops and integrates intelligence

\footnotetext{
* Personal communication between Victoria Heath, ERDC-CERL and Mark Fincher. Fort Benning, Georgia, 2018.
} 
capabilities, concepts and doctrine; and provides world class quality support services to the Huachuca community to enable mission command in support of Army and joint operations and the continued evolution of Fort Huachuca (U.S. Army 2018h).

This 73,142-acre site is unique for its extreme location in the arid southwest. As such, water conservation is of the utmost importance and historically, the post has minimal problems with maintaining water quality hence, flushing is essentially nonexistent. Fort Huachuca is a small installation that serves a population of around 12,000, about half of which are overnight residents. Note that the information that follows was either directly calculated or collected by phone conversation and email.*

Fort Huachuca's GOCO potable water distribution system is supplied by groundwater. The demand is roughly 1.1 MGD. Relative to the other surveyed installations, this site occupies a large area, and has an average population and level of consumption. The installation's percentage flushed is very low, less than $0.04 \%$. This low level is attributed to the installation's sophisticated level of water conservation, its excellent water quality, and its formal flushing program that has specifically been developed around routine/non-routine flushing conducted by the operations and maintenance (O\&M) contractor and the Fire Department. The low level of ground water withdrawal is maintained primarily to conserve critical resources to support current and future, military missions. So, while flushing is minimal, the site was able to achieve the reduction in water usage (Figure 6-7) by maintaining a highly effective water conservation program that employs both reuse and recharge facilities.

* Personal communication between Victoria Heath, ERDC-CERL and Christopher Higgins, Fort Huachuca, Arizona, 2018. 
Figure 6-6. Fort A.P. Hill monthly flushing in gallons over the course of 3 years.

Reduction attributed to the use of the Fire Flow Pro diffuser system.

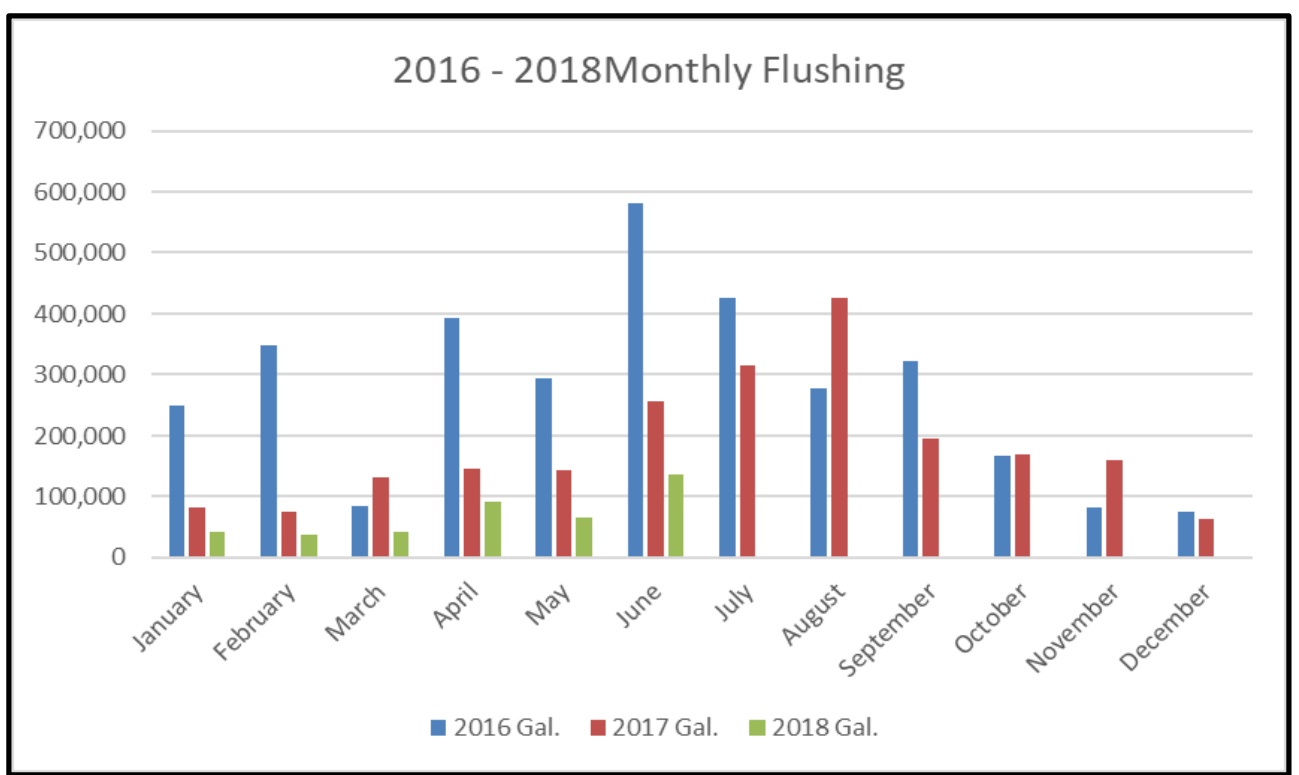

Source: Gary Manville. Fort A.P. Hill, Virginia, 2018.

Figure 6-7. Water consumption (pumped) at Fort Huachuca from 1992 to 2017 plotted against Fort population.

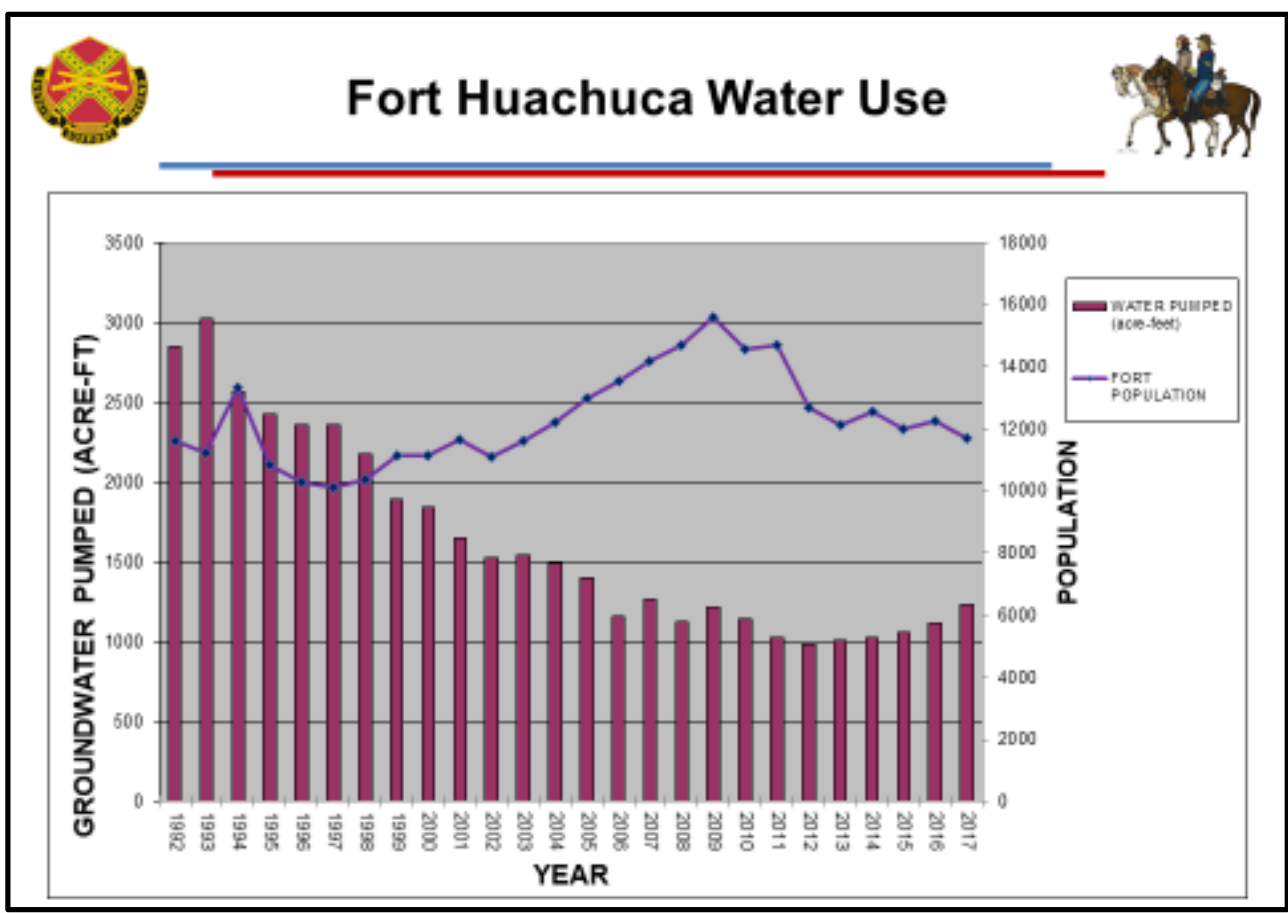

Source: Christopher Higgins, Fort Huachuca, Arizona, 2018. 


\subsubsection{Fort Carson, Colorado: Decreased storage capacity}

Fort Carson, Colorado, is a moderate sized installation that serves a population around 43,000 , over $3 / 4^{\text {ths }}$ of which are overnight residents. The $137,000-$ acre area, which is semi-arid, can suffer from both drought and snowmelt-induced flooding. Note that the information that follows was either directly calculated or collected by phone conversation and email. ${ }^{*}$

Fort Carson's GOCO potable water distribution system is supplied by surface water. The demand is roughly 2.2 MGD. The installation's percentage flushed (about $0.9 \%$ ) is in the same range as many other installations. This site deserves credit for reducing its flushing to that current percentage. In 2015, a water storage study was conducted for the Installation by the U.S. Army Corps of Engineers (USACE), Omaha District. The study indicated that chlorine residuals were too low, a condition that resulted from keeping too much water in storage. To comply with State of Colorado regulations regarding residual chlorine levels, a $1 \mathrm{MG}$ tank on both the east pressure zone and west pressure zone sides were taken offline and drained in 2015. Removal of the tanks from regular service and the addition of chlorine feeders at the points of entry and at booster pump stations have enabled the Installation to meet chlorine residual requirements. The installation also uses unidirectional flushing to maintain chlorine residuals throughout the system. The installation maintains two tanks offline to accommodate the potential for future expansion; demolition is not desired. The study is provided in the Technical Library.

To reduce TTHM to allowable limits, the two $1 \mathrm{MG}$ tanks that remain online each have a GridBee(r) mixer installed. A Medora Corporation portable airoperated chlorine injection system (Model DBS-125) with a 20-gallon total capacity and pumping capacity of $0.5 \mathrm{gpm}$ to $4 \mathrm{gpm}$ is compatible with the mixers and will be used to maintain residual chlorine levels in the tanks. A portable chlorine injection system was also applied for. However, the booster was not state approved. By the time the state had reviewed the submittal paperwork for the booster system and sent a request for more information to make an approval decision, Fort Carson had already resolved their issues through modification of the flushing plan and rotating the storage tanks. There was also a concern brought up by our contractors about hauling equipment up the tanks each time they had to use it and if need be

\footnotetext{
* Personal communication between Victoria Heath, ERDC-CERL and Vincent Guthrie, Fort Carson, Colorado, 2018.
} 
manually boosting the tanks would be less cumbersome than hauling the equipment from tank to tank. So approval was given low priority. It should also be noted that adding more chlorine is not always the best solution since it will often result in unacceptable levels of TTHM and other DBPs (disinfectant byproducts).

In summary, Fort Carson removed about half of its water storage volume. This reduction did not compromise fire suppression needs since it was determined that the required amount of fire suppression water could be supplied from the local utilities and there was no need to redundantly cover the need with Army-owned tank supplies. Consequently, it can be extrapolated that the quantity flushed is about half the previous amount considering that the total volume of the system was essentially cut in half. Storage reduction can therefore be considered as a source of significant savings in flushing if the reduction in quantity is safe, justified, and planned properly. 


\section{Best Management Practices}

A flushing program should encompass a comprehensive approach to improve water quality. It should consider changes in source water, treatment, type and condition of mains, velocities, pressure zones, and water age (Mercer 2010). An effective program will consider each distribution system individually and will anticipate and prevent water quality problems and costumer complaints. From this perspective, it is recommended that each installation review this report and determine the BMPs that may apply to their specific water distribution system and flushing needs.

The first type of BMP for flushing will optimize the treatment process and distribution system; i.e., to make changes to lessen the need to flush. The second type of BMP will optimize flushing as a practice (once it has been determined that flushing is necessary and cannot be reduced).

\subsection{Optimizing treatment and distribution system}

The initial design of a treatment plant and water distribution system should not be the last time that treatment and distribution optimization are considered. Proper management of a water distribution system requires constant monitoring, which is fundamental to the operation, understanding, and evaluation of any system (Ohio AWWA 2014). Specific water distribution system performance criteria to monitor include disinfectant residual levels, pressure, and main breaks (Martin and Ries 2014). Options to improve performance should be considered whenever system performance deteriorates or whenever it can be significantly improved. Flushing is the main option used to improve disinfectant residual levels. Other options that can reduce the need to flush include making improvements to existing network configurations and designing future networks with the ability to better support contamination response planning and other flushing protocols (Poulin et al. 2010).

\subsubsection{Right sizing}

The design of the potable water distribution system (in most cases also the firefighting system) must ensure that water reaches all areas of need in the quantity suitable for the intended purpose (in this combined scenario, for fire protection). However, the sizing of facilities must balance the need to supply enough water for fire protection with the need to maintain high 
quality potable water. A system with oversized mains that provides volumes of water in excess of actual usage can lead to water stagnation (AWWA 2017b). This creates a need for artificial demand (flushing) at a frequency that matches the system's carrying capacity.

By contrast, reducing the capacity of an oversized system can reduce water age, reduce the production of DBPs, improve disinfectant residual, minimize corrosion, and eliminate taste, odor, and color complaints. Consequently, water quality can be improved by optimizing the water distribution system (Ohio AWWA 2014) to balance the competing objectives of water quality and water volume. Achieving this balance is of critical interest to installations where fire protection is crucial but where population (and water demand) fluctuates greatly, making it difficult to right-size since demands change periodically.

When right sizing a single water distribution system for dual purposes proves too difficult, it may make sense to consider designing separate firefighting and potable drinking water distribution systems. In a design with two separate systems, fire flow water need not meet the strict quality standard for potable water, and the potable water distribution capacity can be built to better match demand (without the additional demand of fire flow). If neither an adjustment to system volume, nor a separation of systems is feasible, then measures to reduce stagnation should be taken. Oftentimes this means creating an artificial demand via flushing although this must be done in a way to minimize water loss.

Note that, from a regulatory standpoint, the decision to size distribution system components, including water lines, appurtenances, and storage facilities, for fire protection must be made by the governing body of the community. There is no legal requirement that dictates the size of a water distribution system (AWWA 2008a).

\subsubsection{Storage tank management}

Water storage tanks and towers essentially represent large portions of the distribution system capacity. Depending on the system design, a tank may be in an area of high demand where the stored water is turned over often, or in an isolated place that results in low water turnover rates, which can lead to aged water. Storage tank water should be completely turned over less than every 3-5 days (Ohio AWWA 2014). If water in the tank is as old or older then the water in the rest of the distribution system, then a change in 
the design of the tank's connectivity should be considered to create a better flow through the tank and better water turnover within the tank. Other options to improve water circulation in the tank might include installation of an aeration system within the tank and/or an adjustment of the inlet of the tank to create self-circulation. Aeration can potentially combat water age related issues and can reduction of volatile DBP concentrations.

Spray stripping is another type of aeration that is new to the industry and that is being considered for storage tanks that have problems with volatile DBPs (Schneider et al. 2018). Essentially, if one type of aeration does not have the desired effect, this and others should be considered. Spray stripping was shown to remove greater amounts of volatile DBPs as system pressure increased (When a change to the distribution storage capacity is infeasible but a reduction in flushing is desired, the individual water age issue should be addressed using one of the other perspectives mentioned in this section.

Figure 7-1). In all aeration systems, the effectiveness of removal is directly related to aeration efficiency. In other words, the system that more effectively aerates a given tank or portion of a water distribution system will remove more DBP volatiles.

In addition to circulation/turnover and aeration of storage tanks, tanks that are not protected cathodically (i.e., using corrosion control by electrode) should also be cleaned every 3 years (Schmitt 2018). Tank cleaning can improve water quality and potentially reduce the need for frequent flushing.

When a change to the distribution storage capacity is infeasible but a reduction in flushing is desired, the individual water age issue should be addressed using one of the other perspectives mentioned in this section. 
Figure 7-1. A Texas American Waters Bernard Acres Tank TTHM (and other DBP) removal with pressure differences in spray stripping.

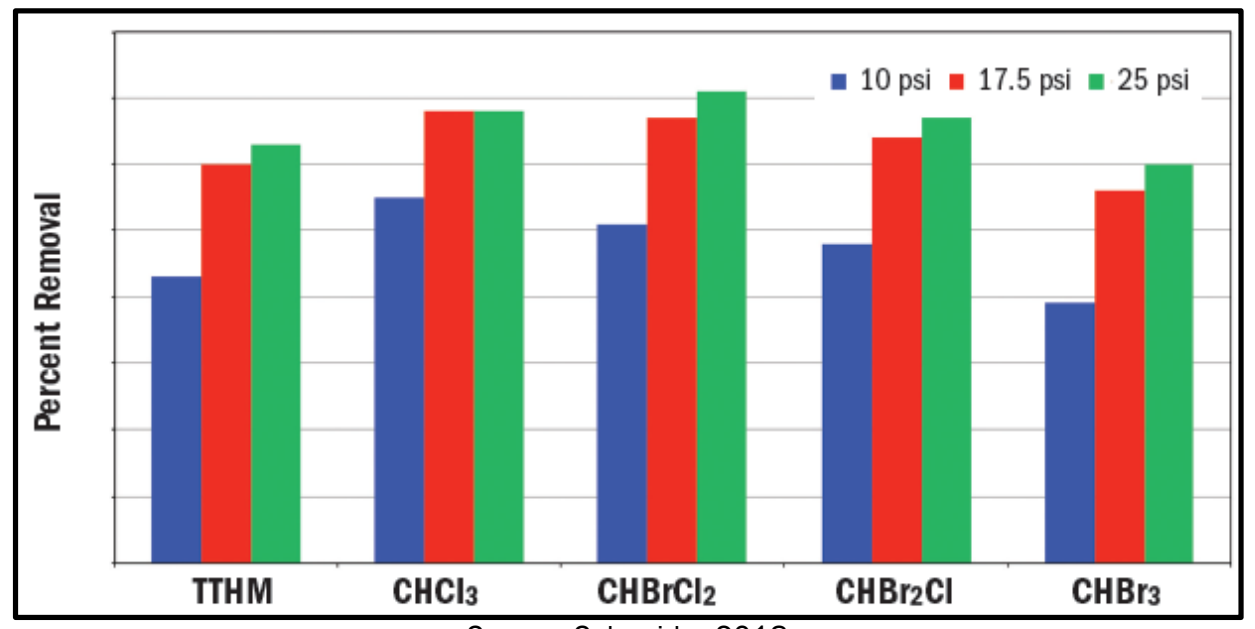

Source: Schneider 2018

\subsubsection{Dead-end looping}

Looping of pipes makes it possible to more effectively flush or scour debris from the system; it also balances water age by circulating water through the whole system so that water quality remains uniform and good. It is wise to devise a network that reaches peripheral areas without creating dead ends and to loop the piping whenever possible to avoid water stagnation within the system at dead-end locations. Otherwise, dead-end stagnation is traditionally addressed with flushing.

\subsubsection{Pipe material and pipe age}

Pipe material and the age of the infrastructure can affect the quality of water and may increase the need to flush. Corrosion can contribute to DBP production or to other quality concerns that are controlled by flushing. Corrosion control is important because corroded iron pipes are essentially a chlorine sink that causes you to lose disinfectant residual. In any case, a reasonable BMP is to regularly access the need to update the distribution system. Note that updating the system need not refer to a complete system overhaul; simpler system updates could include partial replacement or the installation of an in-situ lining to renew the inner surfaces of old pipes with a better material.

If replacement or repair of the infrastructure is not feasible but pipe corrosion is still an issue that requires flushing, then other specific causes of 
corrosion should be investigated. For example, water $\mathrm{pH}$ levels, the presence of trace metals in the water, and other water properties can increase or inhibit the development of corrosion (AWWA 2017b).

Breaks occur most often as a result of improper installation (AWWA 2012). Training before installation or closer consideration during installation could prevent some main breaks. When flushing to clear the system following a repair, it is important to flush only the quantity or water needed to restore the main back to working order. Where flushing is necessary, the only real BMP is to try and capture the flushed water for reuse.

\subsubsection{Treatment plant improvements}

The need to flush for scouring or turnover can sometimes be addressed more directly through treatment plant improvements.

\subsubsection{Biofilm control}

When flushing to control biofilm, first consider the biofilm production factors and address them (Ohio AWWA 2014). Alternative options for biofilm control include decreasing incoming nutrients through a more advanced treatment filtration (enhanced coagulation, activated carbon, source water protection, and more). Also consider the choice of disinfectant and disinfectant dose. A dose should be selected that is penetrating and that matches pipe demand. Other treatments that may inhibit biofilm growth include corrosion control, temperature control, aeration, and such nonconventional means as distillation, reverse osmosis, and electro-dialysis.

\subsubsection{DBP control}

Before flushing to control DBP, consider the source components for production of DBPs. First consider the source of water for potable production. Whether it be well or surface water, the contribution of organic matter can affect the disinfection byproducts produced. It would be worthwhile to consider if an additional treatment step before water is finished could lower the organic matter in finished water enough to reduce the eventual production of DBPs. Additional treatments include advance coagulation and other organic matter capturing mechanisms. Depending on the source of the organic matter content in the water, some disinfectants may be better than others for reducing the quantity of DBPs produced (Hruday and 
Charrois 2012). Hydraulic flow and storage management are the best modes for DBP improvement (Ohio AWWA 2014).

Bench testing the source water against various treatment options has helped guide utilities to an optimal treatment process adjusted to best address their local and seasonal conditions to reduce DBP production and reduce the need for flushing. " Such source water specific tests can access multiple treatment options to achieve the highest removal possible. Although time intensive, this approach of bench testing treatments could lead to a more dynamic and optimized treatment plan that lessens the need for flushing.

\subsection{Optimizing flushing}

The BMPs described in the following sections address flushing once it has been determined that flushing is necessary and further attempts to reduce the water lost during flushing have been exhausted. Optimizing flushing can involve the application of new technologies and water reuse options.

\subsubsection{Ice pigging}

If the flushing technique used does not reach velocities adequate for biofilm removal, other scouring techniques, such as ice pigging, may be used. Conventional flushing may not reach velocities high enough for scouring, and in older system segments, higher velocities may not be achievable via unidirectional flushing because of the risk of main breaks. In such cases, ice pigging can be used to avoid the longer flushing times that might achieve a greater scouring effect. Ice pigging does not change the flushing velocity but instead adds a grit of ice that aids the scouring effect of the water. Although the ice production involved in the process is energy intensive, ice pigging can potentially reduce water lost since it significantly shortens the time to flush (Fann 2015).

\subsubsection{Dynamic flushing plan}

The flushing program should be based on an assessment of the desired outcomes that guides the development of a flushing protocol, with an underlying objective to minimize water lost. A scheduled and documented valve exercise program is one component of optimized distribution systems (Martin and Ries 2014). Flushing must occur for both water quality

\footnotetext{
* Russel Ford, David Cornwell, and Erik Rosenfeldt. 2014. New Developments in Managing Disinfection Byproducts. American Water Works Association (AWWA) Webinar slides. 8 October 2014.
} 
maintenance and fire protection tests; however, in some cases water can be conserved by simultaneously flushing the distribution system and performing hydrant testing. If efforts are combined, quality-related flushing should be coordinated with fire flow testing (not the reverse) (Van Arsdel 2012). This combined fire and water quality flushing plan exemplifies a BMP that considers all the objectives to achieve better optimization.

A well developed, water-conserving, well-considered plan still has another goal to meet-to remain dynamic. Source water composition, water demand, climate, and other contributing variables change annually (and seasonally); the flushing plan should be dynamic enough to adjust to these changing conditions. This may be possible by using software, or by establishing a simple procedural review to catch and address changes in the system that require adjustment to the flushing plan to minimize water loss.

\subsubsection{Water reuse}

It can be difficult to reuse flushed water. In many cases, it is simply impossible to capture and reuse the water being flushed due to the high velocity and volume of water being released. One installation reported that it has reused flushed water by filling water tankers and using the water for irrigation. ${ }^{*}$ Other installations have used flushed water for dust control. ${ }^{\dagger}$ Note that some states require water released to the environment to be de-chlorinated before release (USEPA 2017) depending on the chlorine concentrations present. This complicates the reuse approach.

\subsubsection{Fire hydrant testing}

BMPs for a flushing program that serves both fire protection and water distribution systems would depend on the size of the system relative to the necessary fire protection quantities, and on the population fed by the system. If the population using the water is large and the firefighting capacity is equally large, then the water turnover should be high enough to avoid many distribution system issues; there would be less need for flushing to maintain water quality. However, if the system feeds a small population but still requires great quantities for fire protection, low water turnover

\footnotetext{
* Personal communication between Victoria Heath, ERDC-CERL and Vincent Guthrie, Fort Carson, Colorado, 2018.

† Personal communication between Victoria Heath, ERDC-CERL and Christopher Woodruff, Fort Irwin, California, 2018.
} 
rates would result in stagnant water and create a need for water quality management. In this second case, BMPs must be considered.

Public fire hydrants should be flow tested every 5 years to verify capacity and marking of the hydrant (hydrants are classified and marked by rated flow). Public fire hydrants should be flushed at least annually to verify operation, address repairs, and verify reliability. Procedures are contained in NFPA 291 (NFPA 2016).

AWWA (1989) recommends that fire hydrants be inspected annually. An inspection is essentially a momentary flush, which includes no time requirement for the open hydrant; it simply must be opened to ensure that the hydrant is operational. For this reason, fire hydrant inspection is easily done in tandem with any annual flushing system conducted for quality control-if the process is conducted annually and system wide.

It is recommended that flow tests be conducted every 5 years (NFPA 2016) to 10 years (AWWA 1989). These tests do not specify a length of time that the hydrant should be open but do require pressure measurements to determine flow-producing capabilities. Once the hydrant has been opened and the measured pressure determined to be adequate, flushing can be discontinued unless the process is otherwise being combined with other flushing procedures.

\subsubsection{FireFlowPro ${ }^{\circledR}$ diffusers}

FireFlowPro ${ }^{\circledR}$ is a type of diffuser available for purchase from Hurco Technologies Inc. This system uses a different flow test nozzle instead of a pitot tube (which is typically inserted into the water stream). The FireFlowPro ${ }^{\circledR}$ system uses a two-part attachment to achieve a highly accurate metering of the water flow, which is recorded in an automatically produced report from the technology software that records an exact account of water flushed.

Typical fire flow testing requires flushing to occur until a certain desired drop in pressure is achieved; in water savings areas flushing is discontinued after a certain number of gallons are flushed. FireFlowPro ${ }^{\circledR}$ software shows the exact amount of water flushed from each hydrant on the computer. The technology saves water because it uses a diffusor attached to a 2.5-in. opening for short period of time (instead of flushing through a 4-in. opening for a long period of time) and because the equipment measures and records pressure, velocity, and discharge. FireFlowPro ${ }^{\circledR}$ can be used 
for unidirectional flushing as well as for fire flow testing. Figure 6-6 shows its water-conserving benefits. ${ }^{*}$ Appendix $\mathrm{H}$ includes a more detailed description of the system.

\subsubsection{NO-DES Inc. technology}

The NO-DES truck-mounted filtration system (Figure 7-2) uses valves to create an aboveground loop between two fire hydrants in the distribution system. This allows the loop to be flushed at scouring velocities while capturing and filtering the water until turbidity reaches an acceptable level or until some other flushing objective has been achieved. It is essentially a zero-loss system of flushing.

Other benefits of NO-DES include its ability to flush larger diameter transmission lines (The Water Values 2015), its ability to retreat for chlorination (NO-DES), and its multiple filter options to address the contaminant of concern included granular activated carbon for DBP removal. ${ }^{\dagger}$

Some states in drought put a temporary hold on flushing during part of the year, sometimes for years at a time. In such locations, the NO-DES system should be seriously considered to maintain a clean distribution system since in many cases flushing cannot be forgone without negative impacts to water quality, and because this may be the only legal flushing option. In cases where flushing has been optimized as much as possible, yet quantities of water lost are still great enough to cause concern, the use of systems like NO-DES to recapture potentially lost water should be used.

Figure 7-3 illustrates the scouring effectiveness of the NO-DES system demonstrated at Naval Base Ventura County (NBVC) Port Hueneme, California. The study accessed the technology's applicability to the NBVC site needs for flushing and did a cost analysis, which showed that for NBVC only, it was more economically feasible to contract the service (8-year payback period) than to purchase the system (23-year payback period). If used regionally or for multiple installations, the results are reversed. It was determined to be more economically feasible to purchase the system ( 1.5-year payback period) than to contract the service (3-year payback period) (Relph

\footnotetext{
*Personal communication between Victoria Heath, Hurco Technologies representative, 2018; and Gary Manville. Fort A.P. Hill, Virginia, 2018.

† Personal Communication between Victoria Heath, ERDC-CERL, and Chris Wilkinson, President No-DES Inc,, Portland Oregon, 2018.
} 
2018). If they choose to cooperate, multiple installations could use this system at a fraction of the cost that would be charged to one location alone.

Figure 7-2. NO-DES truck-mounted system in operation.

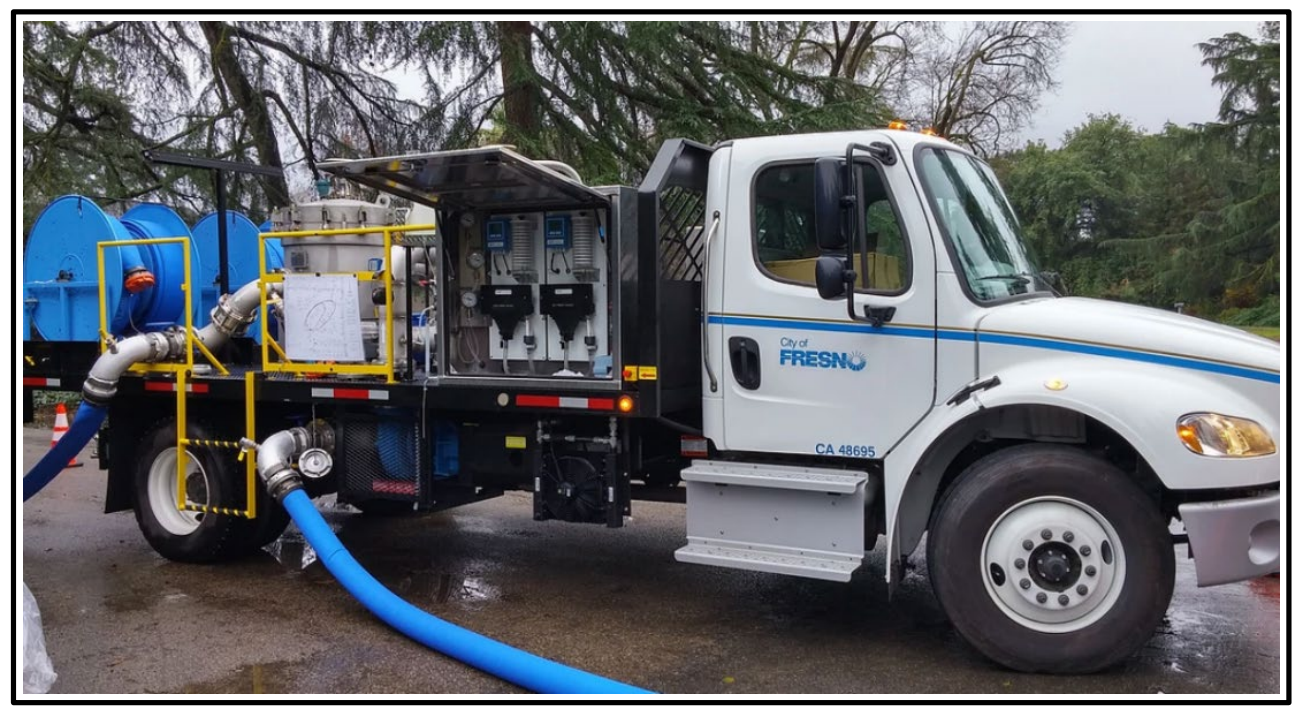

Source: NO-DES Inc. website. Accessed August 2018

Figure 7-3. Two sets of pipe section before and after NO-DES. Top pictures are before images. Bottom pictures are after NO-DES images.

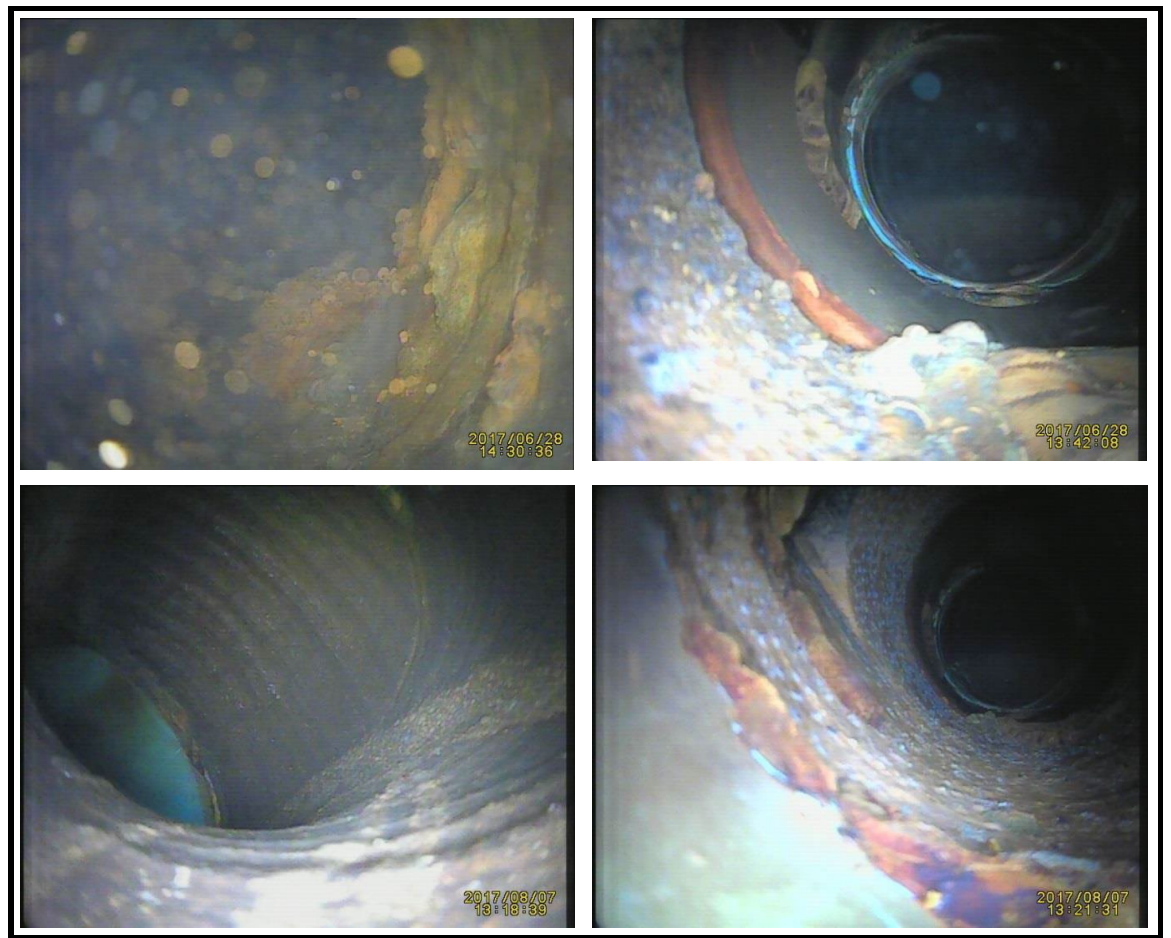

Source: Relph 2018 


\subsubsection{Auto-flushers}

For dead-end locations, the main benefit of implementing an automatic flusher over another type of flushing is that the auto-flusher can offer a slow release that allows for infiltration. For the purposes of flushing, slow release also consumes less water. Although automatic flushers are a viable option for many dead-end flushing concerns, in areas where continuous blow-off auto-flushers are being used, it is wise to consider other potential improvements, from looping dead ends or decreasing pipe diameter size, as well (Friedman et al. 2002). Section 4.3 provides additional information.

\subsubsection{Unidirectional flushing}

UDF is known to use less water overall than conventional flushing because of the sophistication of its valve opening and closing sequences. UDF is said to increase the effectiveness of flushing and reduce the amount of water used by as much as 40\% (Mercer 2010).

However, it is difficult to recommend unidirectional flushing to universally replace conventional flushing. Ideally, planning for UDF should occur during the master planning stage. The model/map developed during master planning can provide a fresh perspective on the system that can clarify where distribution infrastructure improvements can be made (USEPA 2017). Planning and implementation costs to develop a UDF program are estimated to be about $\$ 100,000$ per 100 miles of pipeline (AWWA 2016). The PHC for an installation's given region can offer UDF program development (Golub 2018). Contact your region's PHC Engineering Chief for more information. Section 4.2 includes additional information. 


\section{Conclusions and Recommendations}

\subsection{Conclusions}

This work developed and administered an installation survey to assess the prevalence of potable water flushing at Army installations and to identify available technologies that reduce flushing and/or that reduce water loss due to flushing. An analysis of the survey results indicated that at Army installations, highly individual water quality objectives drive flushing program development. In general, about $65 \%$ of Army installations maintain the amount of potable water flushed below $1 \%$ of total water consumption. However, a few outliers exist in the data showcasing the great differences from one installation to another.

In most cases, a flushing program with a greater level of sophistication would be required to reduce the quantity of water flushed from a distribution system. At sites with high flushing percentages, the elements required to create a more sophisticated program will come at a cost. However, if more resilient flushing programs are desired, some investment in infrastructure improvements, distribution system monitoring, and flushing program management will be required to bring the percentage down to a more acceptable fraction of total consumption.

\subsection{Recommendations}

The following recommended BMPs were identified and documented:

- Right Sizing. The sizing of facilities must balance the need to supply enough water for fire prevention with the need to maintain high quality potable water (p 40).

- Storage Tank Management. Where water in a storage tank is as old or older then the water in the rest of the distribution system, changes to the design of the tank's connectivity should be considered to create a better flow through the tank and better water turnover within the tank (p 41).

- Dead-End Looping. It is wise to devise a network that reaches peripheral areas without creating dead ends and to loop the piping whenever possible to avoid water stagnation within the system at dead-end locations (p 43). 
- Monitor Pipe Material and Pipe Age. Regularly access the need to update the distribution system, including simple system updates such as partial replacement, treatments for corrosion, and measures to mitigate causes of corrosion (p 43).

- Treatment Plant Improvements. Address the need to flush for scouring or turnover directly through such treatment plant improvements as biofilm and DBP control (p 44).

- Optimize Flushing. Where flushing is necessary and attempts to reduce the water lost during flushing have been exhausted, optimize flushing using such new technologies and water reuse options as:

$\circ$ Ice pigging ( $\mathrm{p} 45)$

- Establishing a dynamic flushing plan (p 45)

- Implementing water reuse (p 46)

- Improving the efficiency of fire hydrants testing (p 46)

- Improving fire flow testing procedures ( $\mathrm{p} 47$ )

- Recapturing potentially lost water from flushing (p 48)

$\circ$ Installing auto-flushers (p 50)

- Designing systems to use unidirectional flushing (p 50). 


\section{Bibliography}

\section{Cited Works}

ANSI/AWWA (American National Standards Institute/American Water Works Association). 1993. Disinfecting Water Mains. ANSI/AWWA, C651-92. Denver, CO: AWWA.

- 1992. Disinfection of Water Storage Facilities. ANSI/AWWA Standard C652-92. Denver, CO: AWWA.

- 2008. Cement-Mortar Lining for Ductile-Iron Pipe and Fittings. ANSI/AWWA, C104-08. Denver, CO: AWWA.

—. 2013. Disinfection of Wells. ANSI/AWWA Standard C654-13. Denver, CO: AWWA.

AWWA (American Water Works Association). 2017a. Computer Modeling of Water Distribution Systems, Manual of Water Supply Practices. M32. $4^{\text {th }}$ ed. Denver, CO: AWWA.

- 2017b. Water Quality in Distribution Systems, Manual of Water Supply Practices, $4^{\text {th }}$ ed. M68. Denver, CO: AWWA.

- 2016. Water Audits and Loss Control Programs, $4^{\text {th }}$ ed. M36. $4^{\text {th }}$ ed. Denver, CO: AWWA.

- 2014a. Dry-Barrel Fire Hydrants. AWWA C502-14. Denver, CO: AWWA. http://dx.doi.org/10.12999/AWWA.C502.14.

- 2014b. New Developments in Managing Disinfection Byproducts. AWWA Webinar. 8 October 2014. Denver, CO: AWWA.

2012. DrinkTap, Disinfection Byproducts. Denver, CO: AWWA. http://drinktap.org/Water-Info/Whats-in-My-Water/Disinfection-Byproducts.

2010. WSO: Water Transmission and Distribution. $4^{\text {th }}$ ed. Denver, CO: AWWA. 2008a. Distribution System Requirements for Fire Protection, Manual of Water Supply Practices. M31. $4^{\text {th }}$ ed. Denver, CO: AWWA.

. 2008b. Concrete Pressure Pipe. $3^{\text {rd }}$ ed. M9. Denver, CO: AWWA.

- 2006. Wet-Barrel Fire Hydrants. AWWA C503-05. Denver, CO: AWWA.

- 2002. Distribution System Issue Paper: New or Repaired Water Mains. Denver, CO: AWWA.

. 1993. Installation of Ductile-Iron Water Mains and their Appurtenances. ANSI/AWWA C600-93. Denver, CO: AWWA. 
1989. Installation, Field Testing and Maintenance of Fire Hydrants, Manual of Water Supply Practices. M17. $3^{\text {rd }}$ ed. Denver, CO: AWWA.

Boulos, Paul F., Kevin E. Lansey, and Bryan W. Karney. 2006. Comprehensive Water Distribution Systems Analysis Handbook for Engineers and Planners. Pasadena, CA: MWH SOFT.

Caporale, Federico. 2015. The Ownership of Water Resources in Italy. Global Water Forum.

Fann, Steven. 2015. Demonstration of Ice Pigging Technology to Remove Biofilms in Water Distribution Systems. Blog Post. 4 June 2015. https://serdp-estcp.org/index.php//ProgramAreas/Installation-Energy-and-Water/Water-Conservation/EW-201510.

Friedman, Melinda, Gregory J. Kirmeyer, and Edward Antoun. 2002. "Developing and Implementing a Distribution System Flushing Program." Journal of the American Water Works Association. 94(7):45-121.

FRWA (Florida Rural Water Association). 2012. Fire Protection in Public Water Systems. FRWA Whitepaper. http://www.frwa.net/uploads/4/2/3/5/42359811/frwawhitepaperfireprotection011112.pdf

HQDA (Headquarters, Department of the Army). 2008. Army Facilities Management. Army Regulation (AR) 420-1. Washington, DC: HQDA. https://armypubs.Army.mil/epubs/DR_pubs/DR_a/pdf/web/r420_1.pdf.

Kirmeyer, G., K. Martel, G. Thompson, L. Radder, W. Klement, M. LeChevallier, H. Baribeau, and A. Flores. 2004. Optimizing Chloramine Treatment. $2^{\text {nd }}$ ed. Denver, CO: Water Research Foundation.

Martin, Barb, and Tom Ries. 2014. "Flushing Maintains Distribution System Water Quality." Opflow. Denver, CO: AWWA. https://awwa.onlinelibrary.wiley.com/doi/10.5991/OPF.2014.40.0040.

Mercer, Ken. 2010. "How Important Is a System-Wide Flushing Program?” Opflow. Denver, CO: AWWA. https://awwa.onlinelibrary.wiley.com/doi/abs/10.1002/i.15518701.2010.tb03054.x.

NFPA (National Fire Protection Association). 2016. Recommended Practice for Fire Flow Testing and Marking of Hydrants. NFPA 291. Quincy, Massachusetts: NFPA.

Ohio AWWA. 2014. White Paper on Distribution System Optimization for Water Quality. Joint Distribution/Technology Committee, Distribution Systems Subcommittee. Columbus, Ohio: Ohio Section AWWA. https://epa.ohio.gov/Portals/28/documents/pws/DS_OptimizationWhitePaper_final.pdf.

PNNL (Pacific Northwest National Laboratory). 2012a. Fort Carson Net Zero Water Balance. Richland, WA: U.S. Environmental Protection Agency (USDOE).

. 2012b. Fort Bliss Net Zero Water Balance. Richland, WA: USDOE. . 2012c. Fort Buchanan Net Zero Water Balance. Richland, WA: USDOE. 2012d. Fort Riley Net Zero Water Balance. Richland, WA: USDOE. 
- 2012e. Joint Base Lewis-McChord Net Zero Water Balance. Richland, WA: USDOE.

—. 2012f. Tobyhanna Army Depot Net Zero Water Balance. Richland, WA: USDOE.

- 2013a. Aberdeen Proving Ground Net Zero Water Balance. Richland, WA: USDOE.

—. 2013b. Camp Rilea Net Zero Water Balance. Richland, WA: USDOE.

Poulin, Annie, Alain Mailhot, Nathalie Periche, Louis Delorme, and Jean-Pierre Villeneuve. 2010. "Planning Unidirectional Flushing Operations as a Response to Drinking Water Distribution System Contamination.” Journal of Water Resources Planning and Management 36(6). American Society of Civil Engineers.

https://ascelibrary.org/doi/pdf/10.1061/\%28ASCE\%29WR.1943-5452.0000085.

Reiss, Robert C., Harold Nantz, Kelcia Mazana, Paul Schumi, James Murin, and Christopher Robert. 2010. Unidirectional Flushing: Enhance Water Quality and Improve Customer Relations. OpFlow. Denver, CO: AWWA. https://doi.org/10.1002/j.1551-8701.2010.tb03010.x.

Relph, Tami. 2018. Innovative Hydrant Flushing Using Neutral Output Discharge Elimination System (NO-DES). NESDI \#524. August 2018. TR-NAVFAC-EXWCEV-1808.

Schneider, Orren D., Mark W. LeChevallier, Jian Yang, David M. Hughes, and Harold Reed. 2018. "Control Disinfection Byproducts with Spray Stripping in Storage Tanks.” Opflow. Denver, CO: AWWA. https://doi.org/10.1002/opfl.1037.

Schmitt, Erin. 2018. "Regular Tank Cleaning Is Key to Water Quality.” Opflow. Denver, CO: AWWA. https://doi.org/10.1002/opfl.1034.

SDWA (Safe Drinking Water Act of 1974). As amended 19 June 1986 (PL 99-339) and October 1988 by the Lead Contamination Control Act (PL 100-572) (42 USC 30of, et seq.)

USACE (U.S. Army Corp of Engineers), NAVFAC (Naval Facilities Engineering Command), and AFCESA (Air Force Civil Engineer Support Agency). 2014. Water Storage, Distribution, and Transmission. UFC 3-230-01. Washington, DC: USACE, NAVFAC, and AFCESA. https://www.wbdg.org/FFC/DOD/UFC/ufc_3_230_01_2018_c1.pdf.

- 2013. Fire Protection Engineering for Facilities. UFC 3-600-01. Washington, DC: USACE, NAVFAC, and AFCESA. https://www.wbdg.org/FFC/DOD/UFC/ufc_3_600_01_2016_c2.pdf.

2010. Operation and Maintenance: Inspection, Testing, and Maintenance of Fire Protection Systems. UFC 3-601-02. Washington, DC: USACE, NAVFAC, and AFCESA. https://www.wbdg.org/FFC/DOD/UFC/ufc_3_601_02_2010.pdf.

2001. Operation and Maintenance: Water Supply Systems. UFC 3-230-02. Washington, DC: USACE, NAVFAC, and AFCESA. https://www.wbdg.org/FFC/DOD/UFC/ufc_3_230_02_2001.pdf. 
U.S. Army. 2018a. Fort A.P. Hill. Official Website. https://www.Army.mil/aphill.

. 2018b. Fort Benning Official Website. http://www.benning.Army.mil/.

- 2018c. Fort Bragg Official Website. https://www.bragg.Army.mil/.

—. 2018d. Fort Buchanan Official Website. https://home.Army.mil/buchanan/.

—.2018e. Fort Carson Official Website. http://www.carson.Army.mil/.

—. 2018f. Fort Greely Official Website. http://www.greely.Army.mil.

—.2018g. Fort Hood Official Website. http://www.hood.Army.mil/.

—.2018h. Fort Huachuca. Official Website. http://huachuca-www.Army.mil/.

—. 2018i. Fort Leonard Wood Official Website. https://home.Army.mil/wood/.

USEPA (U.S. Environmental Protection Agency). 2017. Upcoming Research on the Impacts of Water Conservation on Water Quality in Premise Plumbing. Safe and Sustainable Water Resources Research Program webinar. http://www.epa.gov/waterresearch/water-research-webinar-series.

Van Arsdel, John H. 2012. "Best Practices; Maximize Fire Hydrant Flow Testing." Opflow Denver, CO: AWWA. June 2012. https://doi.org/10.5991/OPF.2012.38.0031.

Water Values, The. 2015. Flushing with No Discharge with Jeff Favina. Podcast. http://thewatervalues.com/2015/06/16/flushing-with-no-discharge-with-jeff-favina/

White House, The. 2018. Efficient Federal Operations. Executive Order (EO) 13834. 83 FR 23771(23771-23774). Washington, DC: Executive Office of the President. https://www.federalregister.gov/documents/2018/05/22/2018-11101/efficient-federal-operations.

WMWD (Western Municipal Water District). 2016. Water System Flushing FAQ. http://wmwd.com/DocumentCenter/View/2969/Water-System-Flushing-FAQ?bidld=. 2016b. Water System Flushing Program. https://wmwd.com/418/Water-System-Flushing.

\section{Uncited works}

American Water Works Association. 2013. Disinfection of Water Treatment Plants. AWWA Standard C653-13. Denver, CO: AWWA.

- 2000. Cement Mortar Lining of Water Pipelines in Place - 4 in (100 mm) and Larger. ANSI/AWWA C620-95. Denver, CO: AWWA. http://www.hidrocapital.com.ve/intranet-2/files/biblioteca/pdf/C/C602-00.pdf.

Bhardwaj, Vipin. 2006. "What is the Disinfection Byproducts Rule?" On Tap. Winter 2006. Morganton, West Virginia: National Environmental Services Center, U.S. Department of Agriculture. http://www.nesc.wvu.edu/ndwc/articles/OT/WI06/Q\&A_0T_W06.pdf. 
2004. "Chlorine, Disinfection Byproducts and Waterborne Disease: The Need for Balance Is Essential.” On Tap. Fall 2004. Morganton, West Virginia: National Environmental Services Center, U.S. Department of Agriculture. http://www.nesc.wvu.edu/ndwc/articles/OT/FA04/chlorine.pdf.

Business Wire. 2018. "Washington State Senate Urged to Heed Scientists Concerns About Legionnaires Disease Prior to Vote on Plumbing Standards.” Business Wire. https://www.businesswire.com/news/home/20180226006121/en/Washington-State-SenateUrged-Heed-Scientists\%E2\%80\%99-Concerns.

California Water Boards. 2015. Safe Drinking Water Plan for California: Report to the Legislature. Operational Requirements (for public water distribution systems). https://www.waterboards.ca.gov/publications_forms/publications/legislative/docs/2015/sdwp.pdf.

Carriere, Annie, Vincent Gauthier, Raymond Desjardins, and Benoit Barbeau. 2005. "Evaluation of Loose Deposits in Distribution Systems through Unidirectional Flushing." Journal of the American Water Works Association. 97(9):82-92.

Center for Disease Control. 2016. Disinfection Byproducts. https://www.cdc.gov/safewater/chlorination-byproducts.html

Chlius, James, and Jian Yang. 2016. Hydraulic Modeling of Unidirectional Flushing (UDF) - American Water Case Studies. AWWA Webinar Series. https://www.govevents.com/details/20037/free-webinar-hydraulic-modeling-of-unidirectionalflushing-udf--american-water-case-studies/.

Collins, M. Robin, James P. Malley Jr., and Ethan Brooke. 2009. Reducing Disinfection Byproducts in Small Drinking Water Systems. Durham, New Hampshire: University of New Hampshire, Department of Civil Engineering, Water Treatment Technology Assistance Center. https://www.unh.edu/erg/sites/www.unh.edu.erg/files/WTTACPresentations/dbps_control_in_small_water_systems_maine_2-19-09.pdf.

Cooper, James P. 2017. Hydrant Flow Testing: Purpose, Process \& Experiences. Presentation slides. Highlands Ranch, Colorado: Arcadis Design and Consultancy. https://cdn.ymaws.com/oawwa.org/resource/collection/63584ADD-D7BD4102-BAFA419A0484340A/Hydrant\%20Flow\%20Testing\%20Purpose,\%20Process,\%20Experie.pdf

Cooper, Jim, Frank Parsons, and Tom Walski. 2015. Hydrant Flow Testing. AWWA Webinar. 1 April 2015.

Denver Water. 2018. Denver Water Flushing. http://www.denverwater.org.

DoD (U.S. Department of Defense). 2006. DoD Fire and Emergency Services (F\&ES) Program. DoD Instruction 6055.06. 21. https://www.hsdl.org/?abstract\&did=758036.

Friedman, Melinda J., Andrew S. Hill, Steve H. Reiber, Richard L. Valentine, Gregory Larsen, Angela Young, Gregory V. Korshin, and Ching-Yu Peng. 2010. Assessment of Inorganics Accumulation in Drinking Water System Scales and Sediments. Denver, Colorado: Water Research Foundation and Washington, DC: U.S. Environmental Protection Agency. 
Ghosh, A., C. Seidel, E. Townsend, R. Pacheco, and C. Corwin. 2015. Reducing Volatile Disinfection Byproducts in Treated Drinking Water Using Aeration Technologies. Water Research Foundation and Water Environment Research Foundation Web Report \#4441. Washington, DC: USEPA. https://cfpub.epa.gov/si/si_public_record_report.cfm?Lab=NRMRL\&dirEntryld=309292.

Headquarters, Department of the Army (HQDA). 1982. Sanitary Control and Surveillance of Water Supplies at Fixed Installations. Technical Bulletin (TB) MED 576. https://armypubs.Army.mil/epubs/DR_pubs/DR_a/pdf/web/tbmed576.pdf.

1965. Water Supply for Fire Protection. Army TM 5-813-6. Washington, DC: HQDA.

Hickey, Harry E. 2008. Water Supply Systems and Evaluation Methods, Volume 1: Water Supply System Concepts. Emmitsburg, Maryland: U.S. Fire Administration and Washington, DC: Federal Emergency Management Administration. https://www.usfa.fema.gov/downloads/pdf/publications/water_supply_systems_volume_i.pdf

Hruday, Steve E., and Jeffrey WA Charrois, eds. 2012. Disinfection Byproducts and Human Health. London: IWA Publishing.

NFPA (National Fire Protection Association). 2017. Standard for the Inspection, Testing and Maintenance of Water-Based Fire Protection Systems. NFPA 25. Quincy, Massachusetts: NFPA.

Ritter, James. 2016. "What Are Some Best Practices for Testing and Maintaining Fire Hydrants?” OpFlow. Denver, Colorado: AWWA. https://awwa.onlinelibrary.wiley.com/doi/abs/10.5991/OPF.2016.42.0036.

Rostad, Colleen. 2002. Fate of Disinfection Byproducts in the Subsurface. U.S. Geological Survey (USGS) Open-File Report 02-89. Lakewood, Colorado: U.S. Geological Survey, Denver Federal Center. https://water.usgs.gov/ogw/pubs/ofr0289/cr_fatedisinfect.htm.

Schaefer, Todd. 2015. Fire Hydrant Operation, Maintenance \& Testing. $8^{\text {th }}$ Annual Water Distribution Conference, Addison, IL. 28 April 2015. https://www.isawwa.org/events/EventDetails.aspx?id=499208\&group $=$.

University of California, Irvine. 2014. Best Management Practice D11: Potable Water System Flushing or Chlorination. 5 July 2014. https://www.ehs.uci.edu/programs/enviro/stormwater/BMPs/Potable\%20Water\%20System\%2 OFlushing\%200r\%20Chlorination.pdf.

U.S. Army War College. 2015. How the Army Runs: A Senior Leader Reference Handbook. Carlisle, PA: U.S. Army War College, https://apps.dtic.mil/dtic/tr/fulltext/u2/1001713.pdf

U.S. Army Corp of Engineers (USACE), NAVFAC (Naval Facilities Engineering Command), and AFCESA (Air Force Civil Engineer Support Agency). 2004. Wastewater Treatment Systems Augmenting Handbook, Operation and Maintenance. UFC 3-240-03N (Inactive). Washington, DC: USACE, NAVFAC, and AFCESA. https://www.wbdg.org/FFC/DOD/UFC/INACTIVE/ufc_3_240_03n_2004.pdf. 
U.S. Environmental Protection Agency. 2018a. Secondary Drinking Water Standards: Guidance for Nuisance Chemicals. Washington, DC: USEPA.

https://www.epa.gov/dwstandardsregulations/secondary-drinking-water-standards-guidancenuisance-chemicals

. 2018b. Drinking Water Requirements for States and Public Water Systems, Stage 1 and Stage 2 Disinfection Byproducts. Washington, DC: USEPA. https://www.epa.gov/dwreginfo/stage-1-and-stage-2-disinfectants-and-disinfectionbyproducts-rules

2009. National Primary Drinking Water Regulations. EPA 816-F-09-004. Washington, DC: USEPA. https://www.nrc.gov/docs/ML1307/ML13078A040.pdf.

2004. Understanding the Safe Drinking Water Act. EPA 816-F-04-030. Washington, DC: USEPA Office of Water (4606). https://www.epa.gov/sites/production/files/2015-04/documents/epa816f04030.pdf.

- 2002. New or Repaired Water Mains. Distribution System Issue Paper. Washington, DC: USEPA Office of Water (4601M), Office of Ground Water and Drinking Water. https://www.epa.gov/sites/production/files/2015-

09/documents/neworrepairedwatermains.pdf.

White House, The. 2018. Efficient Federal Operations. EO 13834. Federal Register 83(99):23771-23774, https://www.govinfo.gov/content/pkg/FR-2018-05-22/pdf/201811101.pdf. 


\section{Acronyms and Abbreviations}

\begin{tabular}{|c|c|}
\hline $\begin{array}{l}\text { Term } \\
\text { AFS }\end{array}$ & $\begin{array}{l}\text { Definition } \\
\text { Automatic Flushing System }\end{array}$ \\
\hline ANSI & American National Standards Institute \\
\hline AWWA & American Water Works Association \\
\hline BMP & Best Management Practice \\
\hline CBRN & Chemical, Biological, Radiological, and Nuclear \\
\hline CERL & Construction Engineering Research Laboratory \\
\hline CFD & Computational Fluid Dynamic \\
\hline $\mathrm{coco}$ & Contractor Owned and Operated \\
\hline DBP & Disinfection Byproduct \\
\hline DoD & U.S. Department of Defense \\
\hline EPA & Environmental Protection Agency \\
\hline ERDC & U.S. Army Engineer Research and Development Center \\
\hline ERP & Emergency Response Plan \\
\hline F\&ES & (DoD) Fire and Emergency Services \\
\hline FRWA & Florida Rural Water Association \\
\hline GOCO & Government Owed, Contractor-Operated \\
\hline GOGO & Government-Owned, Government-Operated \\
\hline HAA5 & Haloacetic Acids \\
\hline HQDA & Headquarters, Department of the Army \\
\hline ISAWWA & Illinois Section of the American Water Works Association \\
\hline MGD & million gallons per day \\
\hline NBVC & Naval Base Ventura County \\
\hline NFPA & National Fire Protection Association \\
\hline NO-DES & Neutral Output Elimination System \\
\hline O\&M & Operations and Maintenance \\
\hline ODASA(ES) & $\begin{array}{l}\text { Office of the Deputy Assistant Secretary of the Army for Energy and } \\
\text { Sustainability }\end{array}$ \\
\hline $\mathrm{PHC}$ & Public Health Command \\
\hline PNNL & Pacific Northwest National Laboratory \\
\hline SDWA & Safe Drinking Water Act \\
\hline SF & Standard Form \\
\hline TR & Technical Report \\
\hline TTHM & Trihalomethanes \\
\hline USACE & U.S. Army Corps of Engineers \\
\hline UDF & Unidirectional Flushing \\
\hline UFC & Unified Facilities Criteria \\
\hline
\end{tabular}




\section{Appendix A: Illinois Section American Water Works Association Survey}

A member would like information on flushing procedures at water systems.

Size of Drinking Water Treatment Plant
GOGO
GOCO
$\mathrm{COCO}$
Purchased Water Other

Describe procedure for fire system/hydrant lesting in terms of frequency, approximate flow rate, approximate flow value (summary of all hydrants opened and amount of time open).

Describe routine potable water system flushing procedures, e.g. cleaning biofilm/sediment, after system repairs, etc.

Describe your water monitoring program (periodic testing, continuous monitoring, etc.)

Do you now or have you ever experienced the following? Describe.

Disinfection residuals

Low residual chlorine

Excessive sediment

Turbidity

Biofilms 


\section{Appendix B: Original Project Survey}

Intro Survey conducted by Victoria Heath on behalf of Elisabeth Jenicek, Army Corp of Engineers Energy Branch. Research under the direction of Dr. Mark Kodak, Program Manager in the Office of the Deputy Assistant Secretary of the Army for Energy \& Security based out of the pentagon.

Goal To develop installation guidelines to minimize water loss from distribution system flushing.

Q1 Contact information of the person who can discuss; installation water system flushing programs, hydrant flushing procedures, and/or fire pressure valve tests?

Q2 Have you heard about this project before or any of the individuals involved?

Q3 Who conducts the pre-treatment of your potable water? (Government owned and operated, government owned/contractually operated, contractor owned/operated, or purchased water)

Q4 Do you know your source water? (Deep well, shallow well, well field, surface water, etc.)

Q5 What is the capacity of the system (including any unused portion)? How many gallons per day is the treatment plant able to support at full capacity? What does it operate at now?

Q6 What are the lengths of transmission line and water mains within the fence line? What is the portion that lies outside of the fence line? (Preferably in miles by pipe diameter)

Q7 Describe your water monitoring program. Periodic or continuous measurement of what parameters (disinfectant residual, etc.) and at what locations (finished water at treatment facility, storage tanks, dead ends)?

Q8 Do you now or have you ever had issues with the following. If so, what actions taken to resolve?
Disinfection residuals
Total organic carbon
Color/taste/odor
Low residual chlorine
Volatile organics
Main breaks or leaks
Excessive sediment
Turbidity
Tuberculation

Quality violations

Biofilms

Frequency of Issues

Q9 Do you carry out routine system flushing (for biofilm removal, sediment removal, etc.)? What is the estimated water usage and frequency of flushing program? (Flow rate of open valve GPM $x$ duration of time left open or calculation of pressure, pipe diameter, and time open)?

Q10 Have you ever or do you regularly spot-flush in response to new building additions, main repairs, or taste and color complaints? If so, at what lengths (what would be your estimated water use for these flushes)? Is any of this water re-used in some way? If not, where is it discharged to?

Q11 What about for hydrant valve exercising and adequate fire hydrant flow testing? How often does fire related flushing take place and what is the estimated water usage?

Q12 Is your water system modeled? In what software, how is it maintained, and what is it used for?

Thank you for your participation! 


\section{Appendix C: Final Project Survey}

Flushing Survey

Heath August 1, 2018

1. Operating System
a. GOGO
b. COGO
c. GOCO
d. $\operatorname{coco}$

2. Source Water

a. Ground

b. Surface (River)

c. Surface (Reservoir)

d. Combination

3. Average work force population $=$

4. Average Residents population $=$

5. Average Daily population $(3+4)=$

6. Avg. Use Gallons per Day (gpd) =

7. Main flushing concern
a. Low Chlorine residuals
b. DBP
c. Excessive Sediment
d. Quality Violations
e. Biofilms
f. Complaints
g. Main breaks
h. Maintenance

8. Flushing Protocol
a. Annual
b. Bi-annual
c. Monthly
d. Weekly
e. As needed
f. Never

9. Flush length based on

a. Chlorine Residuals

b. Turbidity

c. Visual

d. Time

e. Volume

10. Average potable gallons used per year for Fire flow "flushing" =

11. Average potable gallons used per year for all other flushing =

12. Average total potable gallons used per year to flush $(10+11)=$

13. System Modeled

a. Yes

b. No 


\section{Appendix D: Explanation of Altered Survey}

The initial survey briefly introduced the investigators, offices, and goal of the research. The survey asked for basic water distribution system information

- relevant persons of contact

- source water

- potable water supplier

- capacity of the water system

- water main diameters and lengths

- whether the system was modeled.

Questions specifically about flushing included:

- whether the installation or individual had heard of the flushing research done by ACE

- if there was a routine flushing program in place

- how the quality of water was monitored to determine the need for flushing

- if they encountered any of a list of issues that are sometimes treated with flushing

- what the fire flow flushing entailed.

Several good conversations and completed surveys were collected, but it became clear that this first survey requested some less useful information and neglected to ask some other important questions. So, after a few edits, a final version of the survey was drafted. Those individuals who had completed the first survey were asked follow-up questions to fill in any missing information and installations surveyed after the change were only given the revised draft.

The revised survey changed in the following ways

- The questionnaire was simplified from a sentence structure to a multiple choice and fill in the blank structure ensuring that the questions being asked would be answered in a way comparable across installations.

- The basic water distribution system information was reduced to the questions of source water, potable water supplier, and whether the system was modeled. 
- Additional distribution system questions now included:

○ the average total use of potable water in gallons per day

○ average work force population

- average residential population

○ average daily population (workforce + residents).

- Questions specifically about flushing were altered to more pointedly ask

○ the main flushing concern (from a list of options)

○ the current flushing protocol frequency (annual, bi-annual, monthly, etc.)

o the flushing length determinant (time, volume, visual, etc.)

o the estimated average potable gallons of water used in flushing per year.

- Average potable gallons flushed per year was clarified by separation into three parts that asked for:

- average potable gallons used per year for fire flow "flushing"

- average potable gallons used per year for all other flushing

- average total potable gallons used per year to flush (fire flow + other).

The final version of this questionnaire streamlined data compilation and made qualitative information comparable across installations. 


\section{Appendix E: Summary of Survey Results}

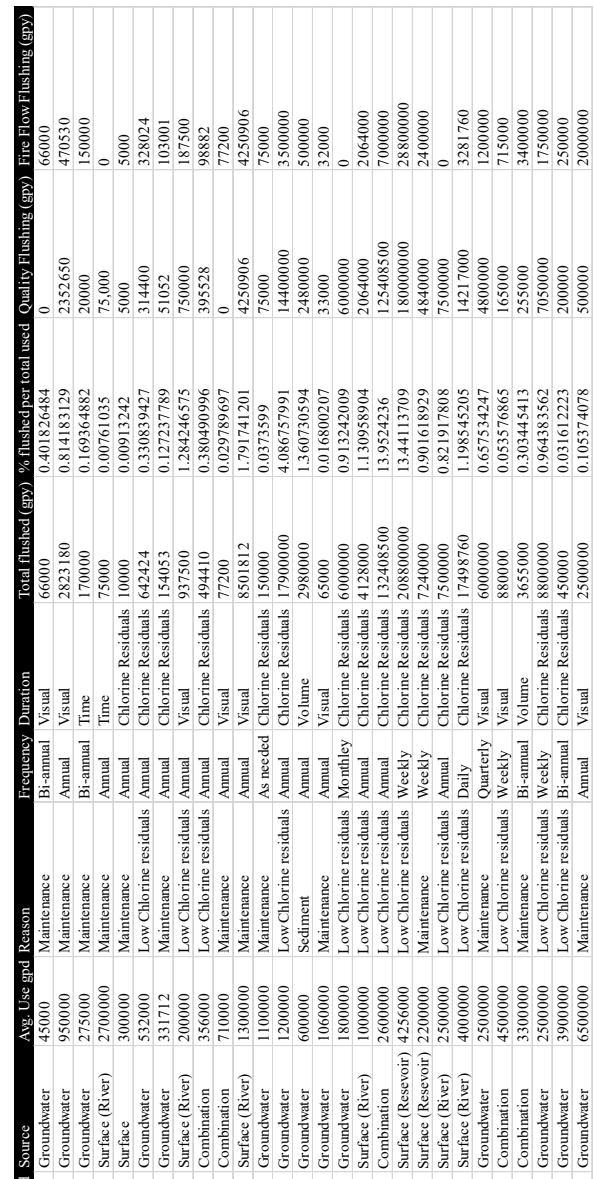

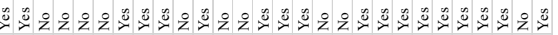

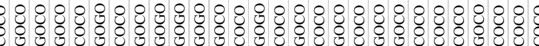

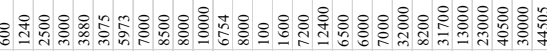

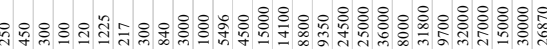

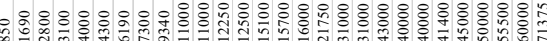

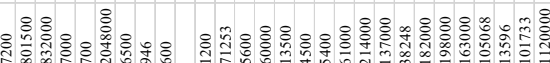

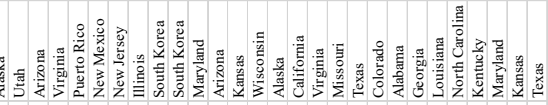

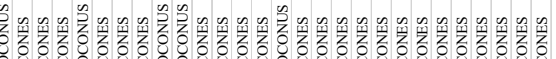

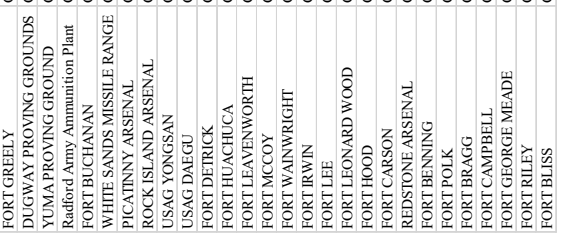




\section{Appendix F: Water Audit Classifications}

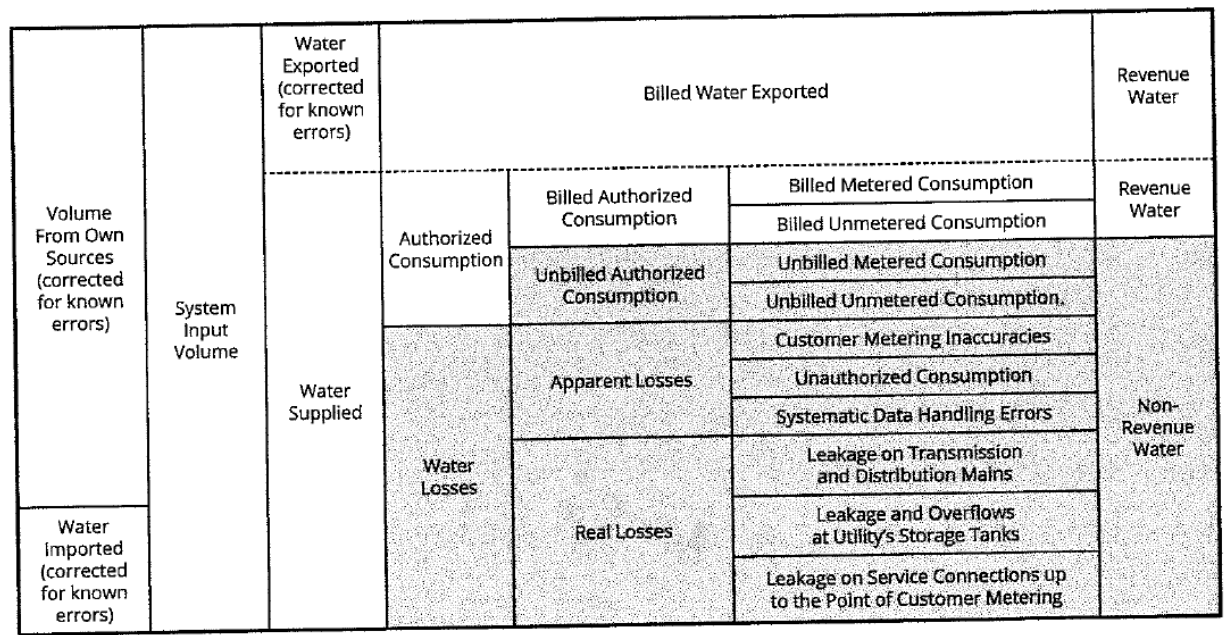

Note: All data in volume for the period of reference, typically one year.

Table 3-1 Water balance terms and definitions

\begin{tabular}{|c|c|}
\hline Water Balance Term & Definition \\
\hline $\begin{array}{l}\text { Volume From Own } \\
\text { Sources }\end{array}$ & $\begin{array}{l}\text { This is the volume of water withdrawn (abstracted) from water resources (rivers, } \\
\text { lakes, streams, wells, etc.) controlled by the water utility, and then treated for potable } \\
\text { water distribution. }\end{array}$ \\
\hline Water Imported & $\begin{array}{l}\text { The Water Imported volume is the bulk water purchased to become part of the Water } \\
\text { Supplied volume. Typically, this is water purchased from a neighboring water utility } \\
\text { or regional water authority. }\end{array}$ \\
\hline $\begin{array}{l}\text { System Input } \\
\text { Volume }\end{array}$ & $\begin{array}{l}\text { The System Input Volume is the annual volume input to the water supply system. } \\
\text { This equals the Volume From Own Sources plus the Water Imported volume. }\end{array}$ \\
\hline Water Supplied & $\begin{array}{l}\text { The Water Supplied volume is the annual volume of treated water delivered to the } \\
\text { retail water distribution system. This equals System Input Volume minus the Water } \\
\text { Exported volume. }\end{array}$ \\
\hline Water Exported & $\begin{array}{l}\text { The Water Fxported volume is the bulk water conveyed and sold by the water utility } \\
\text { to neighboring water sy'stems that exists outside of their service area. }\end{array}$ \\
\hline $\begin{array}{l}\text { Authorized } \\
\text { Consumption }\end{array}$ & $\begin{array}{l}\text { Authorized Consumption is the annual volume of metered and/or unmetered water } \\
\text { taken by registered customers, the water supplier, and others who are authorized to } \\
\text { do so. }\end{array}$ \\
\hline Water Losses & $\begin{array}{l}\text { This is the difference between System Input Volume and Authorized Consumption, } \\
\text { consisting of Apparent Losses plus Real Losses. }\end{array}$ \\
\hline Apparent I.osses & $\begin{array}{l}\text { Apparent Losses involve systematic data handling errors (in the customer } \\
\text { billing process), all types of customer metering inaccuracies, and unauthorized } \\
\text { consumption. }\end{array}$ \\
\hline Real Losses & $\begin{array}{l}\text { Real Losses are the annual volumes lost through all types of leaks, breaks, and } \\
\text { overflorvs on mains, distribution reservoirs, and service connections up to the point } \\
\text { of customer metering. }\end{array}$ \\
\hline Revenue Water & $\begin{array}{l}\text { Revenue Water pertains to those components of System Input Volume that are billed } \\
\text { and produce revenue. }\end{array}$ \\
\hline Non-Revenue Water & $\begin{array}{l}\text { This is the sum of Lnbilled Authorized Consumption, Apparent Losses, and Real } \\
\text { Losses. This value can also be derived by calculating the difference between System } \\
\text { lnput Volume and Billed Authorized Consumption. }\end{array}$ \\
\hline
\end{tabular}




\section{Appendix G: Federal and DoD Policy}

\begin{tabular}{|c|c|c|c|c|}
\hline Jurisdiction & Policy & Year & Mandate & Relevance to flushing \\
\hline $\begin{array}{l}\text { Federal-Environmental } \\
\text { Protection Agency (EPA) }\end{array}$ & $\begin{array}{l}\text { Safe Drinking Water Act } \\
\text { (SDWA) }\end{array}$ & 1974 & $\begin{array}{l}\text { Enforceable water quality standards (primary) and } \\
\text { secondary non-enforceable. Collects drinking water } \\
\text { data. Oversees state drinking water programs. }\end{array}$ & $\begin{array}{l}\text { Flushing often used as a corrective measure for water } \\
\text { quality. Checks compliance and enforces legal } \\
\text { consequences to improper management. State programs } \\
\text { may enforce specific flushing protocols. }\end{array}$ \\
\hline Federal-EPA & SDWA Amendment & 1990 & $\begin{array}{l}\text { Testing requirements and monitoring at the most distant } \\
\text { outlet }\end{array}$ & $\begin{array}{l}\text { The most distant outlet is often the lowest quality water in } \\
\text { the distribution system. Flushing frequently used as ad a } \\
\text { solution to peripheral issues. }\end{array}$ \\
\hline Federal-EPA & SDWA Amendment & 1996 & $\begin{array}{l}\text { Requires consumer confidence reports to provide } \\
\text { guidance, assistance, and public info. }\end{array}$ & $\begin{array}{l}\text { Does not mandate any flushing program but set a precedent } \\
\text { for a more transparent operation. }\end{array}$ \\
\hline Federal-EPA & $\begin{array}{l}\text { SDWA Amendment, } \\
\text { Public Law 107-188, } \\
\text { Public Health Security } \\
\text { and Bioterrorism } \\
\text { Preparedness and } \\
\text { Response Act } \\
\end{array}$ & 2002 & $\begin{array}{l}\text { Requires an Emergency Response Plan (ERP) and Water } \\
\text { Security and Vulnerability Assessments (WSVA) }\end{array}$ & $\begin{array}{l}\text { Required WSVA and ERPs would likely include flushing as a } \\
\text { response to accidental or intentional contamination. }\end{array}$ \\
\hline Federal-EPA & $\begin{array}{l}\text { Stage } 1 \text { Disinfectant } \\
\text { Byproduct (DBP) Rule, } \\
\text { 40CFR141-63FR69390 }\end{array}$ & 1998 & $\begin{array}{l}\text { Reducing exposure to DBPs but setting an enforceable } \\
\text { standard. }\end{array}$ & $\begin{array}{l}\text { Flushing of aged water considered a solution to DBP } \\
\text { exposure reduction. }\end{array}$ \\
\hline Federal-EPA & \begin{tabular}{|l|} 
Stage 2 DBP Rule. \\
40CFR141-71FR388 \\
\end{tabular} & 2006 & $\begin{array}{l}\text { Tightening compliance monitoring requirements for } \\
\text { DBPs }\end{array}$ & $\begin{array}{l}\text { Increased monitoring of compliance may require flushing to } \\
\text { be officially given as 'part of a response plan. }\end{array}$ \\
\hline $\begin{array}{l}\text { Federal- National Fire } \\
\text { Protection Agency } \\
\text { (NFPA) }\end{array}$ & $\begin{array}{l}\text { NFPA } 291 . \\
\text { Recommended Practice } \\
\text { for Fire Flow Testing and } \\
\text { Marking of Hydrants }\end{array}$ & 2016 & $\begin{array}{l}\text { Provides guidance on fire flow tests and marking of } \\
\text { hydrants in order to determine available fire service } \\
\text { water supply from hydrants and to identify deficiencies } \\
\text { which could be corrected to ensure adequate fire flows. }\end{array}$ & $\begin{array}{l}\text { Sets the standard flushing practices for fire flow testing at } \\
\text { every } 5 \text { years and valve exercising annually. }\end{array}$ \\
\hline $\begin{array}{l}\text { Federal-American Water } \\
\text { Works Association } \\
\text { (AWWA) }\end{array}$ & $\begin{array}{l}\text { Field Testing and } \\
\text { Maintenance of Fire } \\
\text { Hydrants (M17) }\end{array}$ & 2016 & $\begin{array}{l}\text { Procedures for fire hydrant design, installation, } \\
\text { operation and maintenance practices. Traces the } \\
\text { development of different styles and contains detailed } \\
\text { instructions for testing. }\end{array}$ & $\begin{array}{l}\text { Recommends flushing practices for fire flow testing at every } \\
5-10 \text { years and valve exercising annually. }\end{array}$ \\
\hline $\begin{array}{l}\text { Federal-American Water } \\
\text { Works Association } \\
\text { (AWWA) }\end{array}$ & $\begin{array}{l}\text { Distribution System } \\
\text { Requirements for Fire } \\
\text { Protection (M31) }\end{array}$ & 2008 & $\begin{array}{l}\text { Designing, operating, and maintaining water distribution } \\
\text { systems as they relate to fire protection and fire } \\
\text { suppression activities and maximize fire protection } \\
\text { benefits, while delivering safe, potable water to } \\
\text { customers. }\end{array}$ & $\begin{array}{l}\text { Recommends flushing practices for fire flow testing at every } \\
\text { 5-10 years and valve exercising annually. }\end{array}$ \\
\hline $\begin{array}{l}\text { Department of Defense } \\
\text { (DOD)-Unified Criteria } \\
\text { (UFC) }\end{array}$ & $\begin{array}{l}\text { ar-420-1, Army Facilities } \\
\text { Management }\end{array}$ & 2008 & $\begin{array}{l}\text { Describes the management of public works activities, } \\
\text { housing and other facilities operations and } \\
\text { management, military construction program } \\
\text { development and execution, master planning, utilities } \\
\text { services and energy management, and fire } \\
\text { and emergency services. }\end{array}$ & $\begin{array}{l}\text { Water distribution systems to be flushed as necessary to } \\
\text { remove accumulated debris. Requires an installation Water } \\
\text { Resource Management Plan (WRMP) to include an effective } \\
\text { water conservation program with best management } \\
\text { practices, water re-use, water metering, and landscape } \\
\text { management. Violations submitted to the Army Compliance } \\
\text { Tracking System. References the use of NFPA } 101 \text { guidelines } \\
\text { which recommend a yearly inspection and } 5 \text { year flow test } \\
\text { on hydrants. }\end{array}$ \\
\hline DOD-UFC & $\begin{array}{l}\text { 3-230-01, Water Storage, } \\
\text { distribution, and } \\
\text { transmission }\end{array}$ & 2014 & $\begin{array}{l}\text { Provides requirements fro typical storage, distribution, } \\
\text { and transmission systems for domestic water, fire } \\
\text { protection and non potable water for the department of } \\
\text { defense (Dodd). }\end{array}$ & $\begin{array}{l}\text { Design of the distribution system often determines the } \\
\text { frequency and location of flushing programs to eliminate } \\
\text { stagnant water. }\end{array}$ \\
\hline DOD-UFC & $\begin{array}{l}\text { 3-230-02, Operation and } \\
\text { maintenance of water } \\
\text { supply system }\end{array}$ & 2001 & $\begin{array}{l}\text { Guidance for operating and maintaining water } \\
\text { supplies, treatment plants, storage facilities, and } \\
\text { distribution systems at military installations. }\end{array}$ & $\begin{array}{l}\text { Recommends flushing annually for sediment removal in a } \\
\text { unidirectional way. Dead ends should be flushed minimum } \\
\text { once a year. Flush in response to odor taste complains as } \\
\text { needed. }\end{array}$ \\
\hline DOD-UFC & $\begin{array}{l}\text { 3-600-01, Fire Protection } \\
\text { engineering }\end{array}$ & 2018 & $\begin{array}{l}\text { Standard for planning and development projects and } \\
\text { design construction and commissioning documental } \\
\text { used for the procurement of facilities. Primary fire } \\
\text { protection criteria reference for design-bid-build and } \\
\text { design-build contracts. }\end{array}$ & $\begin{array}{l}\text { Rules related to hydrant capacity for the given number and } \\
\text { size of structures increases the capacity need of the } \\
\text { distribution system. }\end{array}$ \\
\hline DOD-UFC & $\begin{array}{l}\text { 3-601-02, Operation and } \\
\text { maintenance of fire } \\
\text { protection system }\end{array}$ & 2010 & $\begin{array}{l}\text { Inspect, test, maintain of Engineered fire protection } \\
\text { features in DOD facilities. }\end{array}$ & $\begin{array}{l}\text { Flushing a commonly listed task to used for the purposes of } \\
\text { inspection, testing, and maintenance. Includes the mandate } \\
\text { for a water system vulnerability assessment (WSVA) and } \\
\text { Emergency Response Plan (ERP). }\end{array}$ \\
\hline
\end{tabular}




\section{Appendix H: FireFlowPro ${ }^{\circledR}$ Product Information}

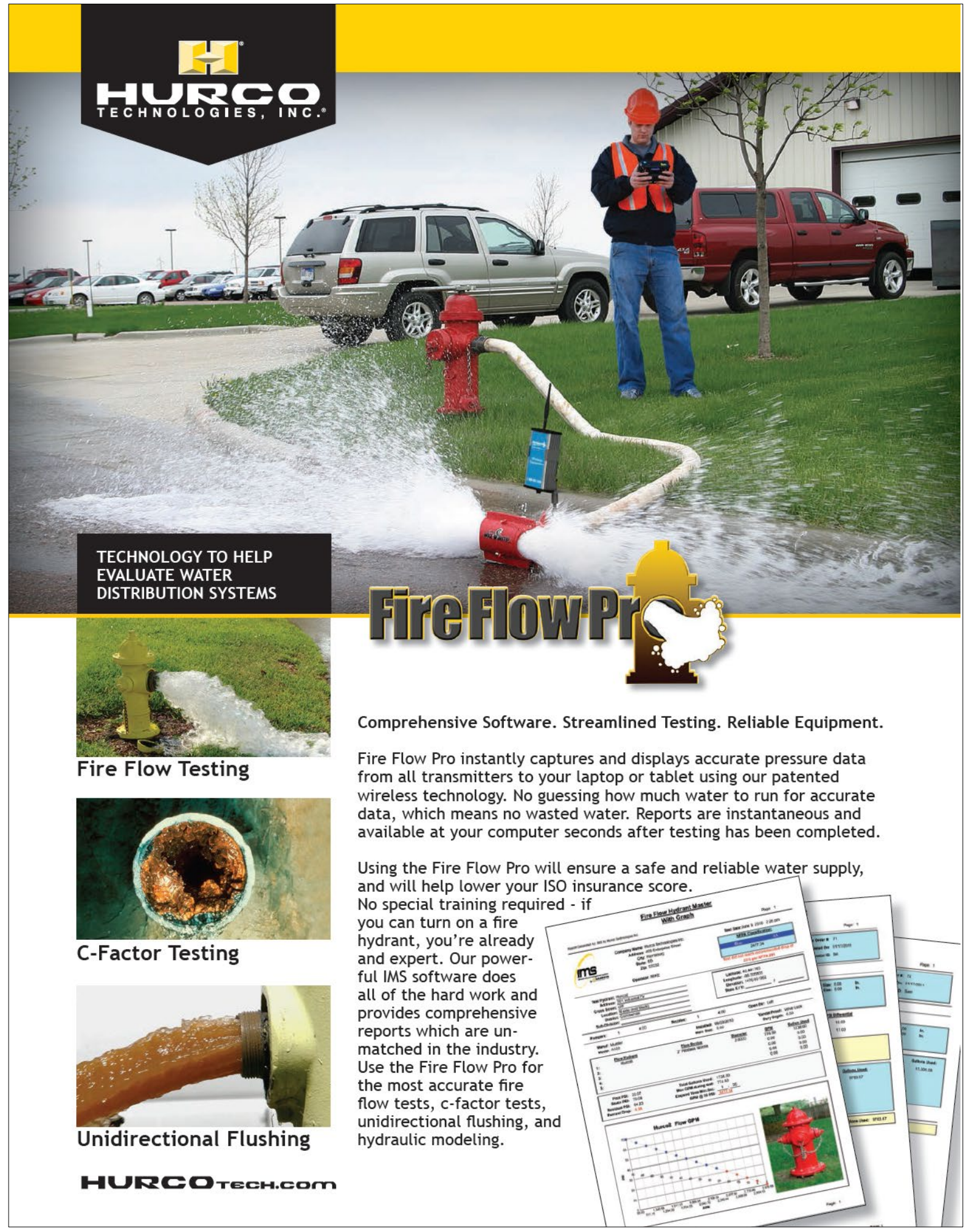




\section{Performance}

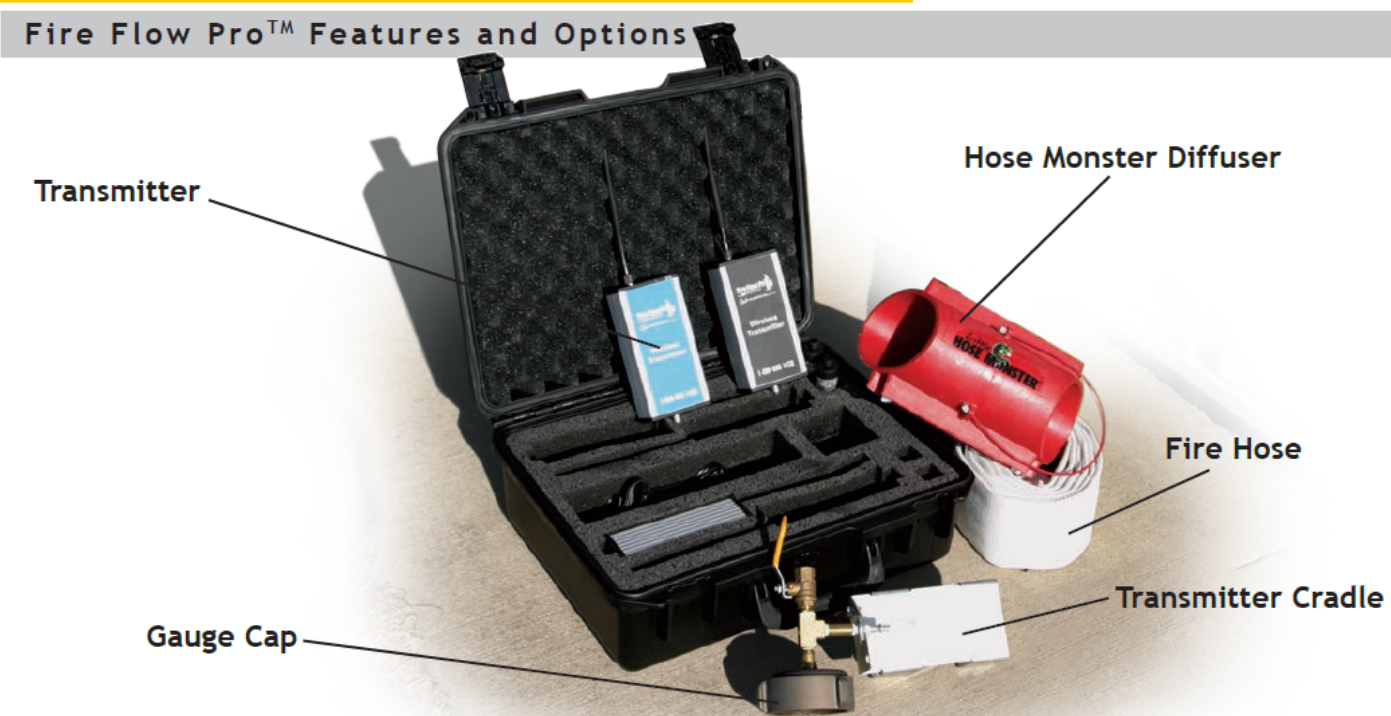

\section{Features}

- Pressure transmitters that utilize $900 \mathrm{MHz}$ RF wireless modules with Mesh capabilities designed to send signals long distance.

- Pressure transducers produce accurate pressure data.

- Lithium Polymer rechargeable batteries give you long term, uninterrupted data transmission.

- Data from the transmitters and transducers is

\section{Required Equipment for Testing}

- For hydrant and valve inventory: - IMS Office

- For basic fire flow testing activities:

- Fire Flow Pro Kit. Includes: 2 Transmitters with Cradles, USB RF Transmitter, IMS Office, IMS Fire Flow Module, IMS Mobile, and 1 Users License

- Diffuser and Pitotless Nozzle

- Fire Hose

- Gauge Cap

- Mobile Computer (we offer the Trimble Yuma, but other mobile devices can be used. Visit our website for requirements)

- Office Computer to manage all testing and maintenance procedures utilizing IMS Office and

\section{Optional Equipment}

- Additional transmitters for backups or testing activities that require more than two transmitters

- Extra IMS Users License if you want to have multiple people working in the program

- Additional diffuser or fire hose if multiple hydrants

to sync to Mobile Computer with IMS Mobile. Both IMS Office and IMS Mobile can reside on the field computer if desired.

- For C Factor Testing:

- Everything required for basic flow testing, plus, - IMS C Factor Module

- Extra Transmitter and cradle. Some situations would benefit from additional transmitters; we will help you determine what's best for your system.

- For Unidirectional Flushing:

- Everything required for basic flow testing, plus, - IMS Unidirectional Module are flowed to reach the desired drop in pressure 


\section{Appendix I: NO-DES, Inc. Product Information}

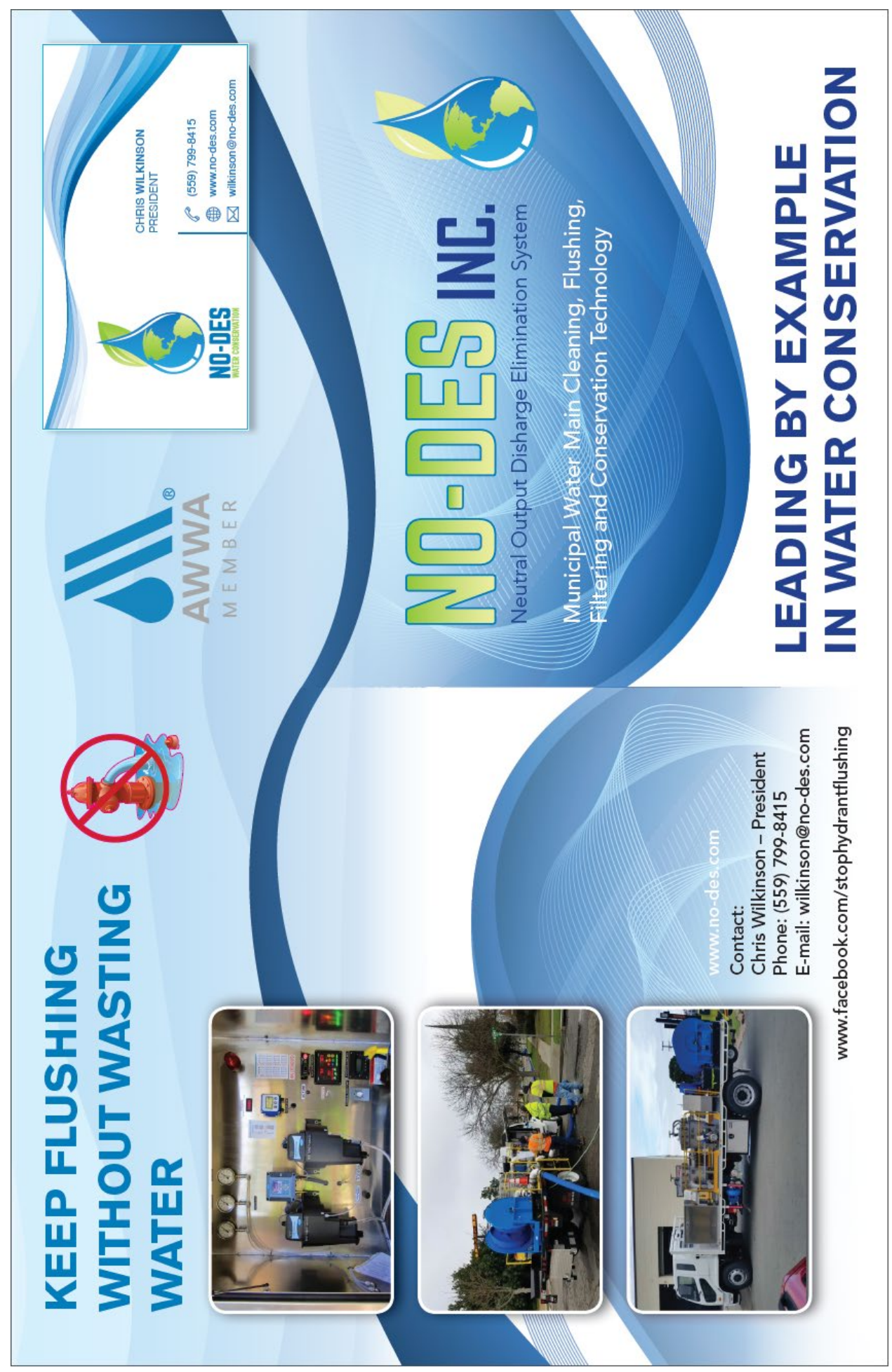




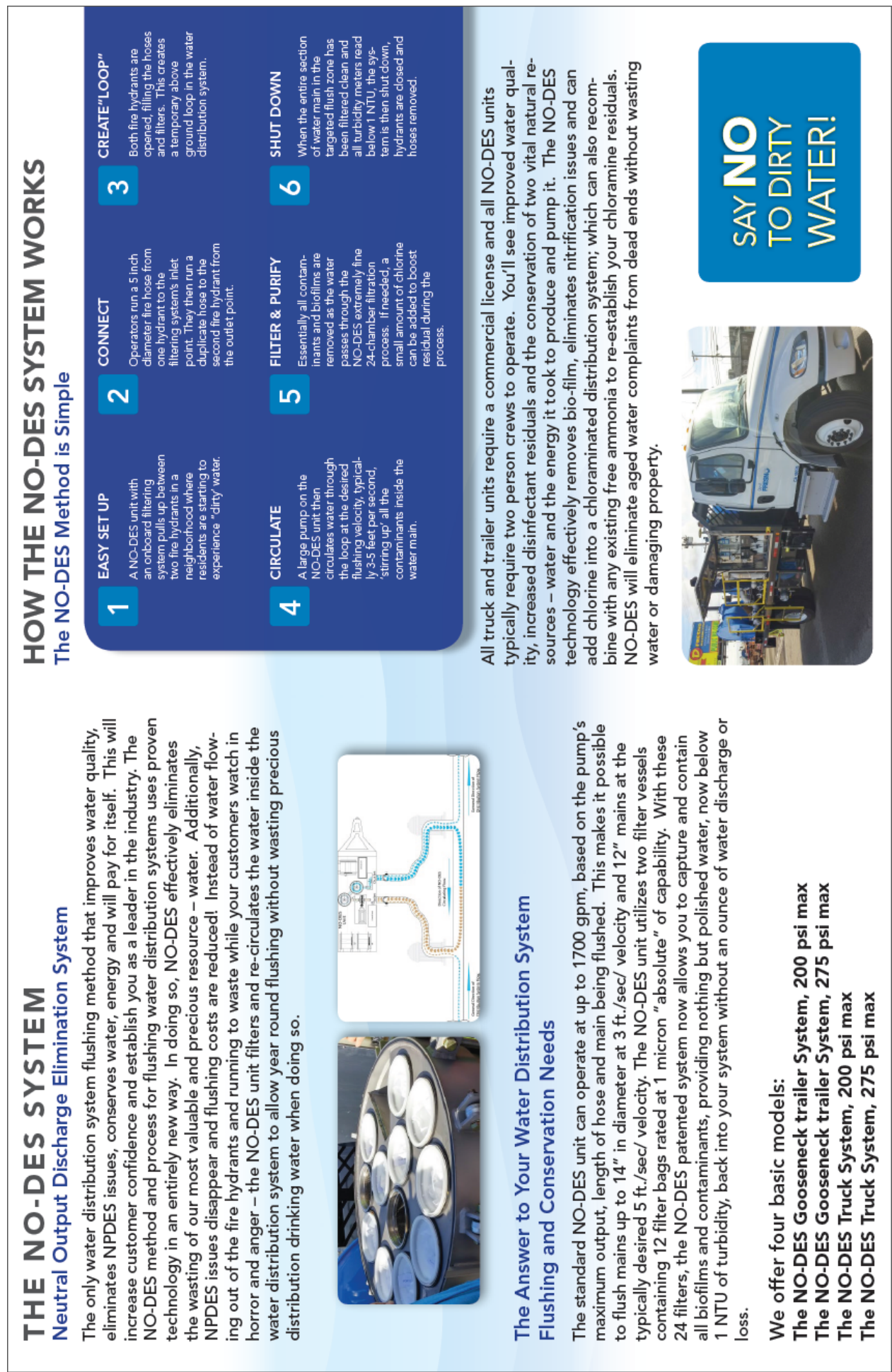




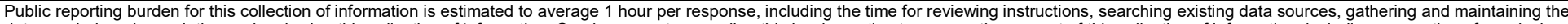

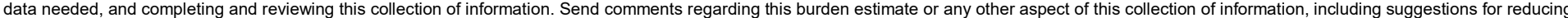

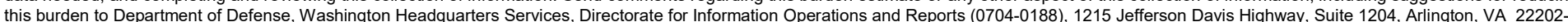

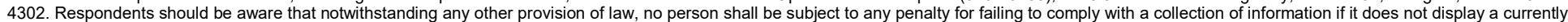

\begin{tabular}{|l|c|} 
valid OMB control number. PLEASE DO NOT RETURN YOUR FORM TO THE ABOVE ADDRESS. \\
\hline 1. REPORT DATE (DD-MM-YYYY) & 2. REPORT TYPE
\end{tabular} $01 / 01 / 2020$ Final Technical Report (TR)

4. TITLE AND SUBTITLE

Guidelines for Minimizing Potable Water Loss Due to Water Distribution System Flushing

5b. GRANT NUMBER

5c. PROGRAM ELEMENT

6. AUTHOR(S)

Elisabeth M. Jenicek, Victoria E. Heath, Noah W. Garfinkle, and Andy Hur

\section{5d. PROJECT NUMBER}

5e. TASK NUMBER

5f. WORK UNIT NUMBER

7. PERFORMING ORGANIZATION NAME(S) AND ADDRESS(ES)

U.S. Army Engineer Research and Development Center (ERDC)

Construction Engineering Research Laboratory (CERL)

PO Box 9005,

Champaign, IL 61826-9005

8. PERFORMING ORGANIZATION REPORT NUMBER

ERDC/CERL TR-20-1

\section{SPONSORING / MONITORING AGENCY NAME(S) AND ADDRESS(ES)}

Office of the Deputy Assistant Secretary of the Army for Energy and Sustainability

110 Army Pentagon

Washington, DC 20310

10. SPONSOR/MONITOR'S ACRONYM(S)

OASA(IE\&E)

11. SPONSOR/MONITOR'S REPORT NUMBER(S)

\section{DISTRIBUTION / AVAILABILITY STATEMENT}

Approved for public release; distribution unlimited.

\section{SUPPLEMENTARY NOTES}

This work was funded via Military Interdepartmental Purchase Request (MIPR) 11097857, "Development of Guidelines for Minimizing Potable Water Loss due to System Flushing."

\section{ABSTRACT}

Executive Order 13834 (White House 2018) mandates the reduction of water consumption from potable and non-potable water distribution systems to increase readiness and security. Flushing of water distribution systems potentially wastes large quantities of water. This work developed and administered an installation survey to assess the prevalence of potable water flushing at Army installations, and used the information gathered from that survey to identify available technologies to recommend best management practices that reduce flushing and/or that reduce water loss due to flushing. Specific recommendations include changes to lessen the need to flush and practices that optimize necessary flushing.

\section{SUBJECT TERMS}

Water-pipes-Flushing, Water conservation, Water consumption, Drinking water, Military bases

\section{SECURITY CLASSIFICATION OF:}

\section{a. REPORT}

Unclassified

\section{b. ABSTRACT}

Unclassified c. THIS PAGE

Unclassified
17. LIMITATION OF ABSTRACT

SAR
18. NUMBER OF PAGES

83 19a. NAME OF RESPONSIBLE PERSON

19b. TELEPHONE NUMBER

(include area code) 